\title{
Pengantar Matematika Aktuaria 2018
}

\section{BAB I}

\section{AKTUARIA DAN PROFESI AKTUARIS}

Aktuaria adalah cabang ilmu pengetahuan yang merupakan perpaduan dari cabang-cabang ilmu matematika (statistika, khususnya teori peluang), ekonomi, keuangan, manajemen, dan ilmu-ilmu lainnya yang keseluruhan digunakan untuk:

1. Menganalisis, mengelola, dan mengukur dampak keuangan dari resiko mendatang.

2. Mengembangkan dan memvalidasi model-model keuangan untuk membantu pengambilan keputusan.

Aktuaris atau professional aktuaria merupakan orang yang bergerak di bidang aktuaria yang melakukan studi statistika untuk membentuk tabel hidup, menganalisis pendapatan perusahaan, merancang produk dan berkonsultasi dengan staf akunting dalam penyediaan dana dan laporan keuangan. Sektor aktuaria ini digunakan dalam penyediaan data dan laporan keuangan. Jenis usaha yang memerlukan jasa seorang aktuaris, antara lain:

1. Perusahaan asuransi (jiwa, properti, kesehatan, kendaraan, dan lainlain)

2. Bank, perusahaan investasi, konsultan keuangan (dalam masalah investasi, manajemen resiko, merger, akuisisi, dan lain-lain) 


\section{\begin{tabular}{l|l} 
Pengantar Matematika Aktuaria & 2018
\end{tabular}}

3. Pemerintahan atau perusahaan swasta besar (pertanggungan

karyawan: pensiun, kesehatan, jaminan sosial, dan lain-lain).

4. Firma akuntan publik

5. Universitas

6. Sektor-sektor dimana manajemen resiko dibutuhkan

Di bidang asuransi, aktuaria digunakan untuk mendefenisikan, menganalisis, dan membuat program yang berhubungan dengan asuransi jiwa. Disini seorang aktuaris menghitung resiko asuransi, menetapkan cadangan (jumlah uang yang disisihkan untuk klaim asuransi yang tidak dibayarkan) dan premi, menghitung peluang terjadinya bermacam-macam ketidakpastian, merancang dan mengembangkan serta menetapkan nilai suatu produk asuransi yang ditawarkan.

Mengingat pentingnya peranan seorang aktuaris dalam sektor keuangan, peluang kerja untuk profesi ini sangatlah menjanjikan. Data tahun 2014 menyatakan, di Indonesia baru terdapat 175 aktuaris yang diakui oleh Asosiasi Aktuaria Internasional (International Actuaries Association/IAA) sementara idealnya Indonesia memiliki 700 aktuaris. Tabel 1 memperlihatkan kesenjangan antara negara berkembang dan negara maju dalam ketersediaan aktuaris.

Ada dua gelar profesi aktuaris di Indonesi, yaitu:

1. ASAI (Associate of Society of Actuaries of Indonesia)

Untuk memperoleh gelar ini seseorang harus lulus 7 mata ujian, yaitu: 


\section{\begin{tabular}{l|l} 
Pengantar Matematika Aktuaria & 2018
\end{tabular}}

$$
\begin{aligned}
& \text { A10 - Matematika Keuangan } \\
& \text { A20 - Probability dan Statistika } \\
& \text { A30 - Ekonomi } \\
& \text { A40 - Akuntansi } \\
& \text { A50 - Metode Statistika } \\
& \text { A60 - Aktuaria } \\
& \text { A70 - Pemodelan dan Teori Resiko }
\end{aligned}
$$

2. FSAI (Fellow of Society of Actuaries of Indonesia)

Untuk mendapatkan gelar ini, seseorang harus bergelar ASAI dan lulus mata ujian:

F10 - Investasi dan Manajemen Aset

F20 - Manajemen Aktuaria

dan salah satu dari:

F31 - Aspek Aktuaria dalam Asuransi Jiwa

F31 - Aspek Aktuaria dalam Dana Pensiun

F31 - Aspek Aktuaria dalam Asuransi Umum

F31 - Aspek Aktuaria dalam Asuransi Kesehatan

Saat ini, di Indonesia, pendidikan formal untuk aktuaria bisa diperoleh di Universitas Indonesia (D3 Aktuaria, S1 Matematika KBK Aktuaria, MM Aktuaria), Universitas Trisakti (D3 Aktuaria, S1 Matematika KBK Aktuaria), Institut Teknologi Bandung (S2 Aktuaria), dan Universitas Gajah Mada (S2 Matematika KBK Aktuaria). Sementara ujian profesi dilaksanakan oleh PAI 


\section{\begin{tabular}{l|l} 
Pengantar Matematika Aktuaria & 2018
\end{tabular}}

(Persatuan Aktuaris Indonesia) yang mendapat lisensi dari FSA (Fellow Society of Actuaries).

Tabel 1. Perbandingan Aktuaris di Beberapa Negara Tahun 2006

\begin{tabular}{|l|c|c|}
\hline \multicolumn{1}{|c|}{ Negara } & Jumlah Aktuaris & Rasio per 1 juta penduduk \\
\hline Australia & 1.243 & 73,92 \\
\hline Cina & 58 & 0,05 \\
\hline Perancis & 1.880 & 32,6 \\
\hline Indonesia & 134 & 0,6 \\
\hline Jepang & 1.077 & 8,69 \\
\hline Amerika Serikat & 16.696 & 68,29 \\
\hline Kanada & 2.443 & 95,97 \\
\hline Singapura & 114 & 43,07 \\
\hline Thailand & 17 & 0,35 \\
\hline Hongkong & 298 & 45,54 \\
\hline
\end{tabular}

Sumber: International Actuaries Association (IAA) 


\section{Pengantar Matematika Aktuaria 2018}

\section{BAB II}

\section{BUNGA}

\section{A. Bunga dan Pengaruhnya.}

Salah satu faktor yang menyebabkan munculnya bunga adalah karena uang memiliki nilai waktu dan biasanya selalu turun dibandingkan dengan barang. Penurunan nilai tikar uang ini biasanya disebut inflasi. Misalnya, satu juta rupiah pada suatu waktu tidaklah sama dengan satu juta rupiah yang diterima beberapa tahun sebelumnya jika dibandingkan dengan kuantitas barang yang setara. Sebagai contoh, tahun 2004 harga satu kg beras adalah Rp.4.000,- sehingga satu juta rupiah setara dengan $250 \mathrm{~kg}$ beras. Bandingkan dengan tahun 2015 dimana harga satu kg beras adalah Rp.20.000,- sehingga satu juta rupiah hanya setara dengan $50 \mathrm{~kg}$ beras. Untuk mempertahankan kesetaraan itulah orang memunculkan konsep bunga.

Untuk itu, pada bagian ini akan dijelaskan konsep bunga dikaitkan dengan nilai uang sekarang dan nilai uang mendatang.

\section{Definisi}

Bunga (interest) adalah kompensasi (berupa uang) yang dibayarkan sebagai jasa atas uang yang dipinjamkan atau diinvestasikan.

Suku/tingkat bunga adalah perbandingan antara bunga dengan uang yang dipinjamkan/diinvestasikan untuk jangka waktu tertentu. 


\section{\begin{tabular}{l|l} 
Pengantar Matematika Aktuaria & 2018
\end{tabular}}

Misalkan P adalah besarnya modal yang diinvestasikan dan B adalah bunga yang dibayarkan untuk satu periode peminjaman. Maka, tingkat bunga, misalkan i dapat dihitung melalui:

$$
\mathrm{i}=\frac{\mathrm{B}}{\mathrm{P}}
$$

Konsep ini menjadi basis dari semua perhitungan ekonomi kapitalis sehingga uang menjadi kehilangan fungsi sosial. Misalnya, jika seseorang punya uang sepuluh juta rupiah dan ada temannya yang membutuhkan untuk pengobatan, tentu saja tanpa bunga dan mungkin baru dibayar beberapa bulan lagi, sementara ada tawaran lain dari seorang pedagang yang kekurangan modal untuk meminjam selama tiga bulan dan bersedia memberi bunga cukup besar. Yang mana yang dipilih?

Padahal, menurut ilmuwan dan norma agama, bunga lebih banyak memberikan dampak negatif ketimbang positif. Plato (427-347 SM) mengatakan bahwa bunga menyebabkan perpecahan dan perasaan tidak puas dalam masyarakat serta merupakan alat golongan kaya untuk mengeksploitasi golongan miskin. Sementara Aristoteles (384-322 SM) menyatakan bahwa fungsi uang adalah sebagai alat tukar (medium of exchange) bukan alat menghasilkan tambahan melalui bunga.

Selain ilmuwan, agama-agama samawi khususnya juga memiliki pandangan negatif terhadap bunga. Berikut nukilan dari tiga kitab suci agama Yahudi, Kristen, dan Islam. 


\section{\begin{tabular}{l|l} 
Pengantar Matematika Aktuaria & 2018
\end{tabular}}

1. Jika engkau meminjamkan uang kepada salah seorang umatku, orang yang miskin diantaramu, maka janganlah engkau berlaku sebagai penagih hutang terhadap dia, janganlah engkau bebankan bunga terhadapnya. (Taurat: Kitab Eksodus 22:25)

2. Dan jikalau kamu meminjamkan sesuatu kepada orang karena kamu berharap akan menerima sesuatu daripadanya, apakah jasamu? Orang-orang berdosapun meminjamkan kepada orang berdosa, supaya mereka menerima kembali sama banyak. Tetapi kasihilah musuhmu dan berbuatlah baik kepada mereka dan pinjamkan dengan tidak mengharapkan balasan, maka upahmu akan besar dan kamu akan menjadi anak-anak Tuhan Yang Maha Tinggi, sebab ia baik terhadap orang yang tidak tahu berterimakasih dan terhadap orangorang jahat (Injil: Lukas 6;34-35)

3. Hai orang-orang yang beriman, bertaqwalah kepada Alah dan tinggalkan sisa-sisa riba (yang belum dipungut) jika kamu (sungguh) beriman. Jika tiada kamu lakukan (demikian), maka ketahuilah bahwa Allah dan Rasulnya akan memerangi kamu. Tapi jika kamu bertaubat (dari pengambilan riba), maka bagimu pokok hartamu; tiada kamu menganiaya dan tiada kamu dianiaya (Al-Baqarah 278-279)

4. Dan uang yang kamu berikan untuk diperbungakan, sehingga mendapat tambahan dari harta orang (lain), uang itu tidak akan mendapat bunga dari Allah. Tapi apa yang kamu berikan berupa zakat untuk mencari wajah Allah, (Itulah yang mendapat bunga). Mereka 


\section{\begin{tabular}{l|l} 
Pengantar Matematika Aktuaria & 2018
\end{tabular}}

(yang berbuat demikian) itulah orang yang beroleh berlipat ganda!

(Ar-Ruum 39)

Dampak yang langsung bisa kita rasakan akibat ekonomi berbasis kapitalisme ini adalah pada beban utang pemerintah. Pembayaran bunga utang periode 2014-2018 rata-rata naik 16,7 persen pertahun, yaitu dari Rp.133,4 trilyun pada tahun 2014, Rp.183,4 trilyun pada tahun 2016, dan direncanakan Rp.247,6 triliun pada tahun 2018. Ditambah dengan utang yang jatuh tempo sebanyak Rp.369 triliun, maka beban utang pemerintah mencapai 32\% dari RAPBN 2018 yang mencapai Rp. 2.204,3 triliun.

Tabel 1. Perkembangan Utang Luar Negeri Menurut Jangka Waktu Sisa dalam Miliar US\$.

\begin{tabular}{|l|l|l|l|l|l|}
\hline & 2013 & 2014 & 2015 & 2016 & $2017^{*}$ \\
\hline Utang Jangka Pendek (<1 & 56.29 & 59.26 & 55.50 & 54.71 & 56.30 \\
\hline Pemerintah & 9.53 & 7.50 & 7.01 & 7.43 & 8.21 \\
\hline BI & 5.98 & 2.87 & 2.32 & 0.64 & 0.67 \\
\hline Swasta & 40.78 & 48.89 & 46.17 & 46.64 & 47.42 \\
\hline Utang Jangka Panjang ( 1 & 209.82 & 234.07 & 254.81 & 265.32 & 290.99 \\
\hline Pemerintah & 104.77 & 116.30 & 130.38 & 147.44 & 164.95 \\
\hline BI & 3.28 & 3.06 & 2.89 & 2.77 & 2.80 \\
\hline Swasta & 101.77 & 114.71 & 121.54 & 115.10 & 123.24 \\
\hline Total Utang & 266.11 & 293.33 & 310.31 & 320.03 & 347.29 \\
\hline
\end{tabular}

* s/d November

Sumber : BI

Secara rasio terhadap Produk Domestik Bruto (PDB), utang pemerintah Indonesia pada 2017 adalah sekitar 35\%. Memang jika dilihat dari rasio utang alias debt to GDP ratio, rasio utang Indonesia masih relatif 


\section{\begin{tabular}{l|l} 
Pengantar Matematika Aktuaria & 2018
\end{tabular}}

rendah untuk ukuran internasional. Tabel 2 memperlihatkan perubahan rasio utang luar negeri terhadap PDB.

Tabel 2. Indikator Beban Utang Luar Negeri Indonesia dalam Persen.

\begin{tabular}{|l|r|r|r|r|r|}
\hline & 2013 & 2014 & 2015 & 2016 & \multicolumn{1}{c|}{2017} \\
\hline $\begin{array}{l}\text { Rasio Utang Jangka Pendek } \\
\text { berdasarkan Jangka Waktu }\end{array}$ & & & & & \\
Sisa Terhadap Total Utang & 21.15 & 20.20 & 17.86 & 17.10 & 16.07 \\
\hline Rasio Utang Terhadap Ekspor & 123.12 & 139.46 & 168.39 & 176.20 & 170.01 \\
\hline Rasio Utang terhadap PDB & 29.13 & 32.95 & 36.09 & 34.31 & 34.54 \\
\hline
\end{tabular}

Sumber : BI

Dampak lain yang bisa dirasakan semua orang dari ekonomi berbasis bunga ini adalah ketimpangan pendapatan antara orang kaya dan orang miskin yang diukur dengan menggunakan koefisien/indeks/rasio Gini (Gini Coefficient/Index/Ratio). Rasio Gini ini memiliki rentang 0-1 dimana 0 menunjukkan kesamaan/pemerataan pendapatan yang sempurna dan 1 menunjukkan ketidaksamaan/ketimpangan yang sempurna juga (1 orang menguasai semua pendapatan/konsumsi, yang lain tidak mendapatkan apaapa). Data Bank Dunia yang terakhir (2017) menunjukkan Rasio Gini tertinggi adalah 0,215 (Finlandia) dan terendah 0,634 (Afrika Selatan).

Tabel 3. Rasio Gini Indonesia.

\begin{tabular}{|l|l|l|l|l|l|}
\hline & 2013 & 2014 & 2015 & 2016 & 2017 \\
\hline Rasio Gini & 0.406 & 0,414 & 0,402 & 0,413 & 0,405 \\
\hline
\end{tabular}




\section{\begin{tabular}{l|l} 
Pengantar Matematika Aktuaria & 2018
\end{tabular}}

Rasio Gini Indonesia selama lima tahun terakhir tidak mengalami perbaikan yang signifikan seperti terlihat pada Tabel 3. Rasio ini meningkat karena sebelum 2005 angkanya masih dibawah 0,35 dan sebelum 2010 angkanya masih dibawah 0,40. Meningkatnya Rasio Gini ini menunjukkan golongan menengah ke atas Indonesia lebih banyak menikmati pertumbuhan ekonomi dibandingkan golongan miskin Indonesia.

\section{B. Prinsip Pengenaan Bunga}

Berdasarkan prinsip perhitungannya, bunga dibedakan menjadi bunga tunggal dan bunga majemuk. Bunga majemuk digunakan pada sebagian besar aplikasi termasuk dalam asuransi. Berikut akan dijelaskan konsep masing-masing.

\section{Bunga tunggal/sederhana (Simple Interest)}

Pada sistem ini, bunga hanya dikenakan terhadap pokok pinjaman dalam setiap jangka waktu/periode transaksi.

Misalkan pokok pinjaman sebesar $\mathrm{P}$ diinvestasikan dengan bunga tunggal i per tahun. Maka dalam satu periode transaksi (satu tahun) bunga yang dikenakan adalah sebesar iP. Dan nilai akumulasi setelah satu tahun S(1) menjadi:

$$
\begin{aligned}
\mathrm{S}(1) & =\text { Modal }+ \text { Bunga } \\
& =\mathrm{P}+\mathrm{iP}
\end{aligned}
$$

Jika diakumulasikan dua tahun, maka nilainya menjadi 


\section{\begin{tabular}{l|l} 
Pengantar Matematika Aktuaria & 2018
\end{tabular}}

$$
\begin{aligned}
S(2) & =S(1)+\text { Bunga } \\
& =P+i P+i P \\
& =P+2 i P
\end{aligned}
$$

Setelah $\mathrm{n}$ tahun, nilai akumulasi akan menjadi

$$
S(n)=P+n i P=P(1+n i)
$$




\section{Pengantar Matematika Aktuaria 2018}

Contoh soal.

1. Tentukan bunga dan jumlah total yang akan diperoleh jika satu juta rupiah diinvestasikan selama 2 tahun dengan suku bunga $12 \%$.

Diketahui:

$$
\begin{aligned}
& \mathrm{P}=\operatorname{Rp} 1.000 .000 \\
& \mathrm{n}=2 \text { tahun } \\
& \mathrm{i}=12 \% \text { per tahun }
\end{aligned}
$$

Ditanya:

$$
\begin{array}{ll}
\text { Bunga } & : \mathrm{n} \text { i } \mathrm{P} \\
\text { Nilai akumulasi dua tahun } & : \mathrm{S}(2)
\end{array}
$$

Jawab:

$$
\begin{aligned}
& \text { n i P }=2 \times 12 \% \times \operatorname{Rp} 1.000 .000,- \\
& =\operatorname{Rp} 240.000,- \\
& S(2)=P+2 i P \\
& \text { = Rp.1.000.000,- + Rp.240.000,- } \\
& =\text { Rp.1.240.000,- }
\end{aligned}
$$

2. Tentukan berapa lama waktu yang dibutuhkan agar uang Rp.1.000.000,menjadi Rp.2.000.000,- dalam suatu tabungan dengan suku bunga tunggal $1 \%$ per bulan.

Diketahui:

$$
\begin{aligned}
& \mathrm{P}=\mathrm{Rp} .1 .000 .000,- \\
& \mathrm{i}=1 \% \text { per bulan } \\
& \mathrm{S}(\mathrm{n})=\text { Rp.2.000.000,- }
\end{aligned}
$$




\section{\begin{tabular}{l|l} 
Pengantar Matematika Aktuaria & 2018
\end{tabular}}

Ditanya :

Periode waktu (bulan) $\quad: \mathrm{n}$

Jawab:

$$
\begin{aligned}
& \mathrm{S}(\mathrm{n})=\mathrm{P}(1+\mathrm{ni}) \\
& \text { Rp.2.000.000 }=\text { Rp.1.000.000 }(1+\mathrm{n} \cdot 0,01) \\
& \frac{2.000 \cdot 000}{1.000 \cdot 000}=1+\mathrm{n} \cdot 0,01 \\
& 2=1+0,01 \mathrm{n} \\
& 1=0,01 \mathrm{n} \\
& \mathrm{n}=100
\end{aligned}
$$

Jadi, dibutuhkan waktu selama 100 bulan atau 8 tahun 4 bulan.

\section{Bunga Majemuk (Compound Interest)}

Bunga majemuk adalah bunga yang dikenakan tidak saja pada modal, tetapi juga pada bunga dari periode-periode waktu sebelumnya. Penjelasannya adalah sebagai berikut. Misalkan sejumlah uang sebesar $\mathrm{P}$ diinvestasikan dengan suku bunga i per tahun. Setelah satu tahun, uang tadi akan menjadi

$$
S(1)=P+i P=P(1+i)
$$

dimana iP adalah bunga tahun tersebut. Jumlah sebesar $\mathrm{P}(1+\mathrm{i})$ itu diinvestasikan lagi pada tahun kedua dan pada akhir tahun akan memperoleh

$$
\begin{aligned}
S(2) & =S(1)+i S(1) \\
& =(P+i P)+i(P+i P)=(P+i P)(1+i)=P(1+i)(1+i)=P(1+i)^{2}
\end{aligned}
$$




\section{\begin{tabular}{l|l} 
Pengantar Matematika Aktuaria & 2018
\end{tabular}}

Jadi, setelah n tahun, jumlah uang yang diterima akan menjadi

$$
S(n)=P(1+i)^{n}
$$

Faktor $(1+\mathrm{i})^{\mathrm{n}}$ kadang-kadang disebut faktor akumulasi. Dan dengan bunga majemuk uang akan tumbuh secara eksponensial. Lihat perbandingannya dengan bunga tunggal pada Gambar 1.

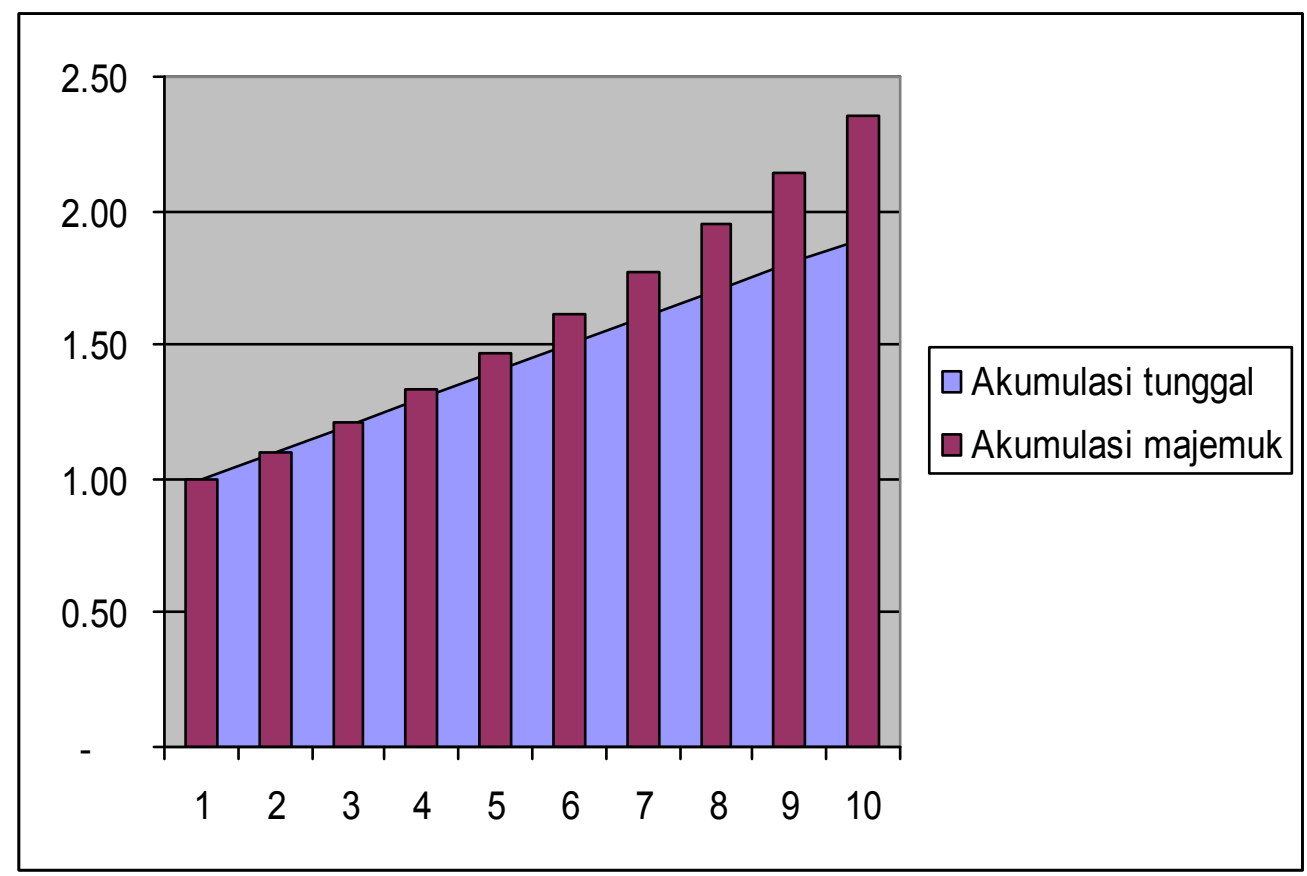

Gambar 1. Perbandingan akumulasi dengan bunga tunggal dan bunga majemuk.

\section{Contoh soal}

1. Tentukan berapa lama waktu yang dibutuhkan agar uang sebesar Rp.1.000.000 menjadi Rp.2.000.000 dalam suatu tabungan dengan suku bunga majemuk $5 \%$ per tahun. 


\section{Pengantar Matematika Aktuaria 2018}

Diketahui

$$
\begin{aligned}
& P=1.000 .000 \\
& i=5 \%=0,05
\end{aligned}
$$

Ditanya

Periode waktu (tahun): $\mathrm{n}$

Jawab:

$$
\begin{aligned}
& S(n)=P(1+i)^{n} \\
& 2.000 .000,-=1.000 .000,-(1+0,05)^{n} \\
& \frac{2.000 .000}{1.000 .000}=1,05^{n} \\
& 2 \quad=1,05^{n} \\
& \ln 2=n \ln 1,05 \\
& n=\frac{\ln 2}{\ln 1,05}=14,2 \approx 15 \text { th }
\end{aligned}
$$

Jadi, dibutuhkan waktu lebih kurang 15 tahun

2. Dana sebesar Rp.5.000.000 di investasikan dengan suku bunga $10 \%$ per tahun selama 10 tahun. Jika bunga hanya bisa diambil pada akhir tahun ke-10, berapa nilai dana beserta bunganya?

Diketahui:

$$
\begin{aligned}
& P=5.000 .000,- \\
& i=10 \%=0,1 \\
& n=10
\end{aligned}
$$

Ditanya: 


\section{\begin{tabular}{l|l} 
Pengantar Matematika Aktuaria & 2018
\end{tabular}}

Nilai akumulasi: S(10)

Jawab:

$$
\mathrm{S}(10)=5.000 .000,-(1+0,1)^{10} \approx 12.968 .700
$$

Meskipun suku bunga adalah nilai per tahun, namun pemberian bunga dapat bervariasi sesuai kesepakatan. Berdasarkan jangka waktu pemberian bunga, bunga dapat dibedakan menjadi beberapa kelompok berikut.

Tabel 5. Jenis Bunga, Banyak Pembayaran, dan Lambangnya.

\begin{tabular}{|l|c|c|}
\hline \multicolumn{1}{|c|}{ Jenis Bunga } & $\begin{array}{c}\text { Banyaknya pembayaran } \\
\text { dalam setahun }\end{array}$ & $\begin{array}{c}\text { Lambang untuk } \\
\text { suku bunga } \\
\text { (umumnya) }\end{array}$ \\
\hline Bunga tahunan & $1 \mathrm{kali}$ & $\mathrm{i}$ \\
\hline Bunga semesteran & $2 \mathrm{kali}$ & $\mathrm{j}_{2}$ \\
\hline Bunga caturwulanan & $3 \mathrm{kali}$ & $\mathrm{j}_{3}$ \\
\hline Bunga triwulanan & $4 \mathrm{kali}$ & $\mathrm{j}_{4}$ \\
\hline Bunga dwibulanan & $6 \mathrm{kali}$ & $\mathrm{j}_{6}$ \\
\hline Bunga bulanan & $12 \mathrm{kali}$ & $\mathrm{j}_{12}$ \\
\hline Bunga mingguan & $52 \mathrm{kali}$ & $\mathrm{j}_{52}$ \\
\hline Bunga harian & 360 atau $365 \mathrm{kali}$ & $\mathrm{j}_{360}$ atau j365 \\
\hline Bunga kontinu & takhingga kali & $\delta$ \\
\hline
\end{tabular}

\section{Suku bunga.}

Ingat, sebelumnya bahwa suku bunga adalah perbandingan bunga dengan modal yang dipinjamkan atau diinvestasikan dalam satu periode (biasanya dalam satuan tahun) sehingga dapat dituliskan dalam persamaan berikut

$$
\text { Tingkat } / \text { suku bunga }=\frac{\text { bunga }}{\text { pokok } / \text { modal }}
$$




\section{\begin{tabular}{l|l} 
Pengantar Matematika Aktuaria & 2018
\end{tabular}}

Jika diperhatikan, suku bunga yang diberikan tidak selalu tetap dan seringkali bervariasi antara produk-produk keuangan. Perbedaan tingkat/suku bunga dipengaruhi oleh banyak hal, diantaranya:

1. Jangka waktu peminjaman atau investasi. Hal ini dapat dilihat pada suku bunga deposito atau obligasi negara yang bervariasi sesuai jangka waktunya. Biasanya yang jangka waktu lebih panjang diberi suku bunga lebih tinggi karena akan memberikan kestabilan lebih bagi pengguna dalam mengelola dana tersebut.

2. Besarnya dana yang dipinjamkan atau diinvestasikan. Hal ini mungkin tidak begitu terlihat secara langsung, tapi cobalah datang ke suatu bank dan jika anda akan mendepositokan sejumlah besar uang, maka anda bisa menegosiasikan suku bunga yang lebih besar dari yang berlaku untuk nasabah lain untuk jangka waktu yang sama.

3. Biaya operasional perusahaan yang mengelola jasa peminjaman atau investasi. Biaya operasional akan mempengaruhi keuntungan perusahaan sehingga jika biaya ini tinggi, maka perusahaan akan mengurangi pembagian kepada investornya dalam bentuk bunga yang rendah.

4. Kondisi makro ekonomi negara saat itu. Hal ini dapat terlihat dari turun naiknya suku bunga Sertifikat Bank Indonesia (SBI) akibat pengaruh makro ekonomi. Ketika pemerintah ingin menekan inflasi dengan cara mengurangi uang beredar, maka BI memberikan suku 


\section{\begin{tabular}{l|l} 
Pengantar Matematika Aktuaria & 2018
\end{tabular}}

bunga yang menarik agar masyarakat tertarik untuk menyimpan uang di bank ketimbang digunakan untuk konsumtif.

Karena rentannya suku bunga terhadap berbagai faktor sehingga berfluktuasi terhadap waktu, maka ada dua penetapan suku bunga yang digunakan dalam transaksi, yaitu suku bunga tetap (fixed rate) dan suku bunga berubah (change rate). Perbedaannya adalah pada fixed rate, suku bunga tetap selama perjanjian/transaksi, sementara pada change rate, suku bunga dapat berubah sewaktu-waktu mengikuti perubahan situasi selama transaksi. Contoh penggunaan change rate adalah pada tabungan bunga harian. Sementara, sebagian kredit menggunakan fixed rate dan sebagian lagi menggunakan change rate.

\section{Suku bunga nominal dan suku bunga efektif Definisi}

Suku bunga nominal adalah suku bunga yang tercantum dalam transaksi (dengan periode tahunan)

Contoh: - tabungan "x" dengan bunga harian 8\%.

- deposito 1 bulan dengan suku bunga 9\%.

- deposito 3 bulan dengan suku bunga 9,5\%.

Suku bunga efektif adalah suku bunga sebenarnya yang diterima dalam satu tahun, walaupun periode pembayarannya bukan tahunan. 


\section{Pengantar Matematika Aktuaria 2018}

Suku bunga ini akan sama nilai bunganya dengan suku bunga majemuk tahunan.

Jika periodenya sama-sama tahunan, maka suku bunga nominal dan efektif diasumsikan sebagai suku bunga tahunan saja.

Contoh:

1) Misalkan deposito 3 bulan dengan suku bunga nominal 12\% dengan pembayaran bunga tiap 3 bulan. Maka, dalam satu tahun ada empat kali penerimaan bunga.

Diketahui $\mathrm{j}_{4}=12 \%$. Maka, suku bunga 3 bulan adalah $\frac{12 \%}{4}=3 \%$.

Perhitungan bunga majemuk setelah 1 tahun ( 4 periode)

$S(4)=P(1+3 \%)^{4}=P(1,03)^{4}=1,1255$

Dengan demikian bunga yang diterima dalam satu tahun adalah

$$
\begin{aligned}
\text { Bunga }=\mathrm{S}(4) & -\mathrm{P} \\
& =1,1255 \mathrm{P}-\mathrm{P}=0,1255 \mathrm{P}
\end{aligned}
$$

Jadi, suku bunga efektif $=\frac{\text { bunga }}{\bmod a l}=\frac{0,1255 \mathrm{P}}{\mathrm{P}}=12,55 \%$

2) Misalkan deposito 1 bulan dengan suku bunga nominal 11,5\% dengan pembayaran bunga tiap 1 bulan. Maka, dalam 1 tahun ada 12 kali penerimaan bunga.

Diketahui $\mathrm{j}_{12}=12 \%$. Maka, suku bunga 1 bulan adalah $\frac{11,5 \%}{12}=0,96 \%$ 


\section{\begin{tabular}{l|l} 
Pengantar Matematika Aktuaria & 2018
\end{tabular}}

Dengan perhitungan bunga majemuk, setelah 1 tahun (12 periode) akan

terakumulasi dana sebesar

$S(12)=P(1+0,96 \%)^{12}=P(1,0096)^{12}=1,12 P$

Sehingga bunga yang diterima dalam satu tahun adalah

Bunga $=\mathrm{S}(12)-\mathrm{P}=1,12 \mathrm{P}-\mathrm{P}=0,12 \mathrm{P}$

Jadi, suku bunga efektif $=\frac{\text { bunga }}{\text { modal }}=\frac{0,12 \mathrm{P}}{\mathrm{P}}=12 \%$

3) Dua skenario investasi berbeda bisa memberikan hasil yang sama walaupun nominal suku bunga tahunan yang diberikan juga berbeda. Contoh berikut mengilustrasikan hal tersebut

Misalkan X punya kesempatan untuk menabung uang di Bank "A" sebesar 1 rupiah pada tabungan yang memberikan bunga tiap bulan dengan suku bunga nominal 5\%. Dengan suku bunga nominal berapa Bank "B" bisa memberikan hasil yang sama untuk dana tersebut jika di Bank B bunga diberikan harian?

Untuk t tahun yang diberikan, jumlah uang akumulatif yang diberikan masing-masing bank adalah:

$$
\begin{aligned}
& \text { Bank "A" }\left(1+\frac{0,05}{12}\right)^{12 t} \\
& \text { Bank “B” }\left(1+\frac{i}{360}\right)^{360 t}
\end{aligned}
$$

Selanjutnya, setelah menyamakan nilai akumulasi, dengan mudah dapat dihitung nominal suku bunga yang membuat pengembalian kedua investasi sama. 


\section{\begin{tabular}{l|l} 
Pengantar Matematika Aktuaria & 2018
\end{tabular}}

\section{Hubungan Suku bunga Efektif dengan Suku bunga Nominal}

Sebelum kita melihat hubungan antara kedua suku bunga, harus diingat bahwa dua suku bunga hanya dapat dibandingkan jika jangka waktu penilaian sama. Contohnya, suku bunga A yang pembayarannya tiap 6 bulan dan suku bunga B yang pembayarannya tiap 4 bulan dapat dibandingkan jika kita menggunakan patokan waktu yang sama, misalkan 1 tahun. Jadi, dalam jangka waktu tersebut suku bunga A sudah diterapkan 2 periode dan suku bunga B sudah diterapkan 3 periode.

Untuk membandingkan suku bunga efektif dan nominal, kita misalkan r : suku bunga nominal s : suku bunga efektif $\mathrm{t}$ : banyaknya pembayaran bunga dalam setahun

Pada modal sebesar $\mathrm{P}$, kita peroleh persamaan nilai akumulatif setelah setahun berikut.

- pembayaran bunga efektif sekali setahun $S(1)=P(1+s)$.

- pembayaran bunga t kali setahun

$$
S(1)=P\left(1+\frac{r}{t}\right)^{t}
$$

sehingga kita peroleh persamaan

$$
\begin{gathered}
P(1+s)=P\left(1+\frac{r}{t}\right)^{t} \\
1+s=\left(1+\frac{r}{t}\right)^{t}
\end{gathered}
$$

Dengan demikian kita peroleh hubungan antara suku bunga efektif dan suku bunga nominal sebagai berikut 


\section{Pengantar Matematika Aktuaria 2018}

$$
\begin{aligned}
& s=\left(1+\frac{r}{t}\right)^{t}-1 \\
& r=t(\sqrt[t]{1+s}-1)
\end{aligned}
$$

Contoh

Hitunglah suku bunga efektif yang setara dengan suku bunga nominal 10\% yang dibayarkan tiap hari (catatan: 1 tahun dihitung 360 hari)

Diketahui

$$
\begin{aligned}
& r=10 \%=0,01 \\
& t=360
\end{aligned}
$$

Ditanya

$$
\mathrm{s}=\ldots . . ?
$$

Jawab

$$
\begin{aligned}
S & =\left(1+\frac{\mathrm{r}}{\mathrm{t}}\right)^{\mathrm{t}-1}=\left(1+\frac{0,1}{360}\right)^{360-1} \\
& =(1+0,00027)^{360}-1 \\
& =1,106-1=0,106=10,6 \%
\end{aligned}
$$

\section{Suku bunga kontinu}

Secara umum, produk-produk keuangan memiliki frekuensi pembayaran berhingga dalam setahun. Disamping yang bersifat berhingga itu, juga tersedia produk investasi dengan periode pembayaran bunga takhingga. Yang menjadi pertanyaan kita adalah bagaimana memperkirakan 


\section{\begin{tabular}{l|l} 
Pengantar Matematika Aktuaria & 2018
\end{tabular}}

suku bunga efektif untuk produk tersebut? Dengan menghitung limit t (frekuensi pembayaran) menuju takhingga, kita peroleh persamaan berikut.

$$
\begin{aligned}
1+s & =\lim _{\mathrm{t} \rightarrow \infty}\left(1+\frac{\mathrm{r}}{\mathrm{t}}\right)^{\mathrm{t}} \\
& =\lim _{\mathrm{t} \rightarrow \infty} \mathrm{e}^{\ln \left(1+\frac{\mathrm{r}}{\mathrm{t}}\right)^{\mathrm{t}}} \\
& =\lim _{\mathrm{t} \rightarrow \infty} \mathrm{e}^{\mathrm{t} \ln \left(1+\frac{\mathrm{r}}{\mathrm{t}}\right)} \\
& =\mathrm{e}^{\lim _{\mathrm{t} \rightarrow \infty} \mathrm{t} \ln \left(1+\frac{\mathrm{r}}{\mathrm{t}}\right)} \\
& =\mathrm{e}^{\mathrm{r}}
\end{aligned}
$$

Jadi, setelah 1 tahun dengan suku bunga kontinu, kita peroleh nilai akumulasi:

$$
S(1)=P \lim _{t \rightarrow \infty}\left(1+\frac{r}{t}\right)^{t}=P e^{r}
$$

Dan setelah $\mathrm{n}$ tahun,

$$
\mathrm{S}(\mathrm{n})=\mathrm{P} \mathrm{e}^{\mathrm{nr}}
$$

Jadi, kalau kita misalkan suku bunga kontinu adalah $\delta$. Maka, kita peroleh hubungan

$$
\mathrm{s}=\mathrm{e}^{\delta}-1
$$

\section{E. Nilai Uang.}

Sebelum kita membahas lebih lanjut, perhatikan transaksi berikut:

- Hari ini A memberi B Rp.5.000.000,-

- 1 tahun lagi B memberi A Rp.2.200.000,-, lalu tahun depannya

Rp.3.300.000,- 


\section{\begin{tabular}{l|l} 
Pengantar Matematika Aktuaria & 2018
\end{tabular}}

Pertanyaan yang mungkin timbul ketika kita mengamati transaksi tersebut antara lain:

- Apakah transaksi tersebut sama-sama menguntungkan?

- Jika tidak, siapa yang lebih diuntungkan?

- Bagaimana menilainya atau membandingkannya?

Untuk menjawab pertanyaan-pertanyaan di atas, kita menggunakan sebuah konsep yang disebut Nilai Uang terhadap Waktu (Time Valuation of Money). Penilaian (terhadap waktu) uang berbasis kepada bunga majemuk. Pada suku bunga majemuk i, perhatikan tabel berikut.

Tabel 6. Perbandingan Nilai Uang pada Waktu Berbeda dalam i

\begin{tabular}{|l|l|l|l|}
\hline \multicolumn{1}{|c|}{$\begin{array}{c}\text { Nilai Uang } \\
\text { Sekarang }\end{array}$} & \multicolumn{3}{c|}{ Nilai Uang Mendatang } \\
\cline { 2 - 4 } & 1 tahun lagi & 2 tahun lagi & n tahun lagi \\
\hline $\mathrm{P}$ & $\mathrm{P}(1+\mathrm{i})$ & $\mathrm{P}(1+\mathrm{i})^{2}$ & $\mathrm{P}(1+\mathrm{i})^{\mathrm{n}}$ \\
$\mathrm{Q}(1+\mathrm{i})^{-1}$ & $\mathrm{Q}$ & $\mathrm{Q}(1+\mathrm{i})^{\mathrm{n}-1}$ & $\mathrm{Q}(1+\mathrm{i})^{\mathrm{n}-1}$ \\
$\mathrm{R}(1+\mathrm{i})^{-2}$ & $\mathrm{R}(1+\mathrm{i})^{-1}$ & $\mathrm{R}$ & $\mathrm{R}(1+\mathrm{i})^{\mathrm{n}-2}$ \\
$\mathrm{~S}(1+\mathrm{i})^{-\mathrm{n}}$ & $\mathrm{S}(1+\mathrm{i})^{-\mathrm{n}+1}$ & $\mathrm{~S}(1+\mathrm{i})^{-\mathrm{n}+2}$ & $\mathrm{~S}$ \\
\hline
\end{tabular}

Selanjutnya, kita definisikan

$$
v=(1+i)^{-1}=\frac{1}{1+i}
$$

sehingga nilai uang sekarang dan mendatang dapat kita tabelkan sebagai berikut 


\section{\begin{tabular}{l|l} 
Pengantar Matematika Aktuaria & 2018
\end{tabular}}

Tabel 7. Perbandingan Nilai Uang pada Waktu Berbeda

\begin{tabular}{|l|l|l|l|}
\hline \multicolumn{2}{|c|}{$\begin{array}{c}\text { Nilai Uang } \\
\text { Sekarang }\end{array}$} & \multicolumn{3}{c|}{ Nilai Uang Mendatang } \\
\cline { 2 - 4 } & 1 tahun lagi & 2 tahun lagi & n tahun lagi \\
\hline $\mathrm{P}$ & $\mathrm{P}(1+\mathrm{i})$ & $\mathrm{P}(1+\mathrm{i})^{2}$ & $\mathrm{P}(1+\mathrm{i})^{\mathrm{n}}$ \\
$\mathrm{Qv}^{1}$ & $\mathrm{Q}$ & $\mathrm{Q}(1+\mathrm{i})^{1}$ & $\mathrm{Q}(1+\mathrm{i})^{\mathrm{n}-1}$ \\
$\mathrm{Rv}^{2}$ & $\mathrm{Rv}^{1}$ & $\mathrm{R}$ & $\mathrm{R}(1+\mathrm{i})^{\mathrm{n}-2}$ \\
$\mathrm{~Sv}^{\mathrm{n}}$ & $\mathrm{Sv}^{\mathrm{n}-1}$ & $\mathrm{~Sv}^{\mathrm{n}-2}$ & $\mathrm{~S}$ \\
\hline
\end{tabular}

Dengan memperhatikan tabel-tabel di atas, kesimpulan yang kita dapatkan adalah:

- Jika waktunya maju, maka nilai uang bergerak eksponensial terhadap (1+i) sesuai kemajuan waktunya.

- Jika waktunya mundur, maka nilai uang bergerak eksponensial terhadap v sesuai kemunduran waktunya.

Kesimpulan:

Secara umum nilai uang terhadap waktu bisa digambarkan sebagai berikut

\begin{tabular}{|c|c|c|c|c|c|c|}
\hline$\ldots$ & 2 tahun & 1 tahun & Sekarang & 1 tahun & 2 tahun & $\ldots$ \\
& yang lalu & yang lalu & & lagi & lagi & \\
\hline$\ldots$ & $\mathrm{Xv}^{2}$ & $\mathrm{Xv}$ & $\mathrm{X}$ & $\mathrm{X}(1+\mathrm{i})^{1}$ & $\mathrm{X}(1+\mathrm{i})^{2}$ & $\ldots$ \\
\hline$\ldots$ & $\mathrm{X}(1+\mathrm{i})^{-2}$ & $\mathrm{X}(1+\mathrm{i})^{-1}$ & $\mathrm{X}(1+\mathrm{i})^{0}$ & $\mathrm{X}(1+\mathrm{i})^{1}$ & $\mathrm{X}(1+\mathrm{i})^{2}$ & $\ldots$ \\
\hline
\end{tabular}

Contoh.

Sebuah pinjaman sebesar Rp.2.000.000,- akan dibayar dua tahun lagi. Tentukan nilai sekarang pinjaman itu, jika suku bunga yang digunakan $10 \%$. Jawab: 


\section{Pengantar Matematika Aktuaria 2018}

Nilai uang sekarang $=2.000 .000(1+0,1)^{-2}$

$$
=2.000 .000\left(\frac{1}{1,1}\right)^{2} \approx 1.652 .900 \text { rupiah }
$$

\section{F. Persamaan Nilai}

Prinsip persamaan nilai adalah:

dua transaksi pada waktu berbeda dianggap ekivalen jika nilainya sama pada suatu waktu yang ditetapkan.

Contoh :

Lukman meminjam uang Rp.1.000.000,- yang diterima satu tahun lagi. Lima tahun lagi ia harus membayar sebesar M. Berapa M jika suku bunga yang disepakati adalah $10 \%$.

Jawab :

Kita bisa membuat diagram untuk masalah di atas

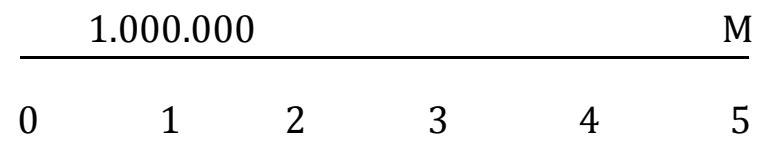

Dengan menggunakan waktu sekarang sebagai patokan, kita peroleh

Nilai pinjaman (sekarang) adalah:

$$
1.000 .000(1+0,1)^{-1}
$$

Nilai pembayaran (sekarang) adalah:

$$
M(1+0,1)^{-5}=M(1,1)^{-5}
$$




\section{\begin{tabular}{l|l} 
Pengantar Matematika Aktuaria & 2018
\end{tabular}}

Persamaan nilai yang kita dapatkan adalah:

$$
\begin{aligned}
1.000 .000(1+0,1)^{-1} & =M(1,1)^{-5} \\
909.091 & =M(1,1)^{-5} \\
M & =909.091(1,1)^{5} \\
& =1.464 .100,-
\end{aligned}
$$

Atau, kita juga bisa menggunakan waktu 5 tahun lagi sebagai patokan sehingga

Nilai pinjaman (5 tahun lagi) adalah:

$$
1.000 .000(1+0,1)^{4}
$$

Nilai pembayaran (5 tahun lagi) adalah:

M

Persamaan nilai yang kita dapatkan adalah:

$$
\begin{aligned}
1.000 .000(1+0,1)^{4} & =M \\
1.000 .000(1,1)^{4} & =M \\
M & =1.464 .100,-
\end{aligned}
$$

Jadi, waktu manapun yang kita gunakan sebagai acuan tidak menjadi masalah selama semua transaksi dinilai pada waktu yang menjadi acuan tersebut.

\section{G. Diskonto Tunggal}

Kadangkala dalam pemberian pinjaman, bunga dibayar di awal transaksi dan dipotong langsung dari pinjaman. Hal ini disebut 


\section{Pengantar Matematika Aktuaria 2018}

diskon/diskonto. Contohnya, pada peminjaman sebesar Rp.1.000.000,- di koperasi, jumlah yang diterima hanyalah Rp.950.000,- karena diterapkan diskonto/potongan Rp.50.000,-

Definisi :

Tingkat/suku diskon/diskonto yang dilambangkan d adalah perbandingan nilai pemotongan terhadap nilai pinjaman

$$
\mathrm{d}=\frac{\text { diskonto }}{\text { Pokok }}=\frac{\mathrm{dP}}{\mathrm{P}}
$$

Jadi, untuk pinjaman sebesar $\mathrm{P}$, diskonto yang dikenakan adalah sebesar $\mathrm{dP}$.

Hubungan antara suku diskonto (d) dengan suku bunga nominal (i)

Perhatikan ilustrasi berikut

\begin{tabular}{lr}
$\mathrm{P}-\mathrm{dP}$ & $\mathrm{P}$ \\
\hline 0 & 1
\end{tabular}

Hal ini berarti modal sebesar P (1 - d) akan menjadi sebesar P setelah satu tahun. Jadi, persamaan nilai yang kita peroleh untuk masalah ini adalah

$$
\begin{gathered}
P(1-d)(1+i)=P \\
1-d=\frac{1}{1+i} \\
d=1-\frac{1}{1+i}=\frac{1+i}{1+i}-\frac{1}{1+i}
\end{gathered}
$$




\section{Pengantar Matematika Aktuaria 2018}

$$
\mathrm{d}=\frac{\mathrm{i}}{1+\mathrm{i}}
$$

dan karena $\mathrm{v}=\frac{1}{1+\mathrm{i}}$, maka kita peroleh persamaan

$$
\mathrm{d}=\mathrm{iv}
$$

Contoh.

1. Misalkan pinjaman sebesar Rp.1.000.000,- hanya diterima Rp.950.000,- pada awal transaksi. Maka, tingkat diskonto yang diberikan untuk pinjaman tersebut adalah sebesar

$$
\begin{aligned}
\mathrm{d}=\frac{\text { pengurangan }}{\text { pinjaman }} & =\frac{50.000}{1.000 .000} \\
& =0,05 \\
\mathrm{i}=\frac{\mathrm{d}}{1-\mathrm{d}}=\frac{0,05}{0,95}=0,053=5,3 \% &
\end{aligned}
$$

2. Pada suku bunga $8 \%$, tentukan berapa diskonto yang diberikan dan uang yang diterima untuk pinjaman sebesar Rp.5.000.000,-?

Jawab:

$$
\begin{aligned}
& i=8 \%=0,08 \\
& d=\frac{1}{1+i} \\
& =\frac{0,08}{1+i}=0,074 \\
& d=\frac{\text { diskonto }}{P}
\end{aligned}
$$




\section{\begin{tabular}{l|l} 
Pengantar Matematika Aktuaria & 2018
\end{tabular}}

$$
\begin{aligned}
& 0,074=\frac{\text { diskonto }}{5.000 .000} \\
& \text { diskonto }=\text { Rp.370.370,- } \\
& \text { uang yang diterima : Rp.5.000.000 - Rp.370.370 = Rp.4.629.630,- }
\end{aligned}
$$

\section{H. Latihan}

1. Pak Roni meminjam uang sebesar Rp.80.000.000,- dari Bank Abadi. Bank tersebut mengenakan tingkat bunga tunggal sebesar 7\% per tahun atas pinjaman tersebut. Jika Pak Roni membayarnya 3 tahun kemudian, berapa besar bunga yang harus dibayarkan?

2. Setelah 120 hari, suatu investasi dengan suku bunga tunggal $11 \%$ per tahun berkembang menjadi Rp.7.000.000,- Hitunglah besar pokok pinjaman dan bunganya.

3. Sejumlah uang diinvestasikan dengan bunga tunggal $12 \%$ per tahun berkembang menjadi Rp.441.000.000,-. Jika diinvestasikan dengan tingkat bunga tunggal 7\% per tahun uang tersebut berkembang menjadi Rp.351.000.000,-
a. Berapa nilai uang yang diinvestasikan?
b. Berapa lama waktu investasi yang diperlukan?

4. Tentukan suku bunga nominal yang dibayar tiap 3 bulan yang setara suku bunga efektif $7 \%$.

5. Tentukan suku bunga efektif yang setara dengan suku bunga nominal 7 \% yang dibayar tiap 2 bulan. 


\section{\begin{tabular}{l|l} 
Pengantar Matematika Aktuaria & 2018
\end{tabular}}

6. Suatu pinjaman mengharuskan peminjam membayar 1 juta setelah 1 tahun, 2 juta setelah 2 tahun, 3 juta setelah 3 tahun dan 4 juta setelah 4 tahun. Pada saat kapankah semua bisa digantikan oleh 1 pembayaran sebesar 10 juta jika suku bunga $4 \%$ ?

7. Sebuah surat bernilai 100 juta 3 bulan dari sekarang dibeli seharga Rp.95.000.000,-. Berapakah suku bunga efektif yang diterima investor?

8. Seorang pedagang membeli barang seharga Rp.50.000.000,. Ia membayar uang muka Rp.10.000.000,-, Rp.10.000.000,- akhir bulan ketiga, dan sisanya dibayar pada akhir tahun. Jika suku bunga 12\% dan dikenakan tiap bulan, berapa yang mesti ia bayar? Jika dibayar akhir bulan keenam, berapa yang mesti ia bayar?

9. Aman meminjam uang sebesar Rp.200.000.000,- tiga tahun lalu. Setahun lalu ia membayar utangnya Rp.200.000.000,-. Akhir tahun ini, ia butuh tambahan modal dan meminjam lagi Rp.150.000.000,-. Berapa utang yang harus dibayarnya dua tahun lagi jka suku bunga yang disepakati $15 \%$ dan dikenakan tiap 4 bulan?

10.X membeli sebuah surat berharga setahun yang lalu dengan cara pembayaran Rp.5.000.000,- tunai dan 2.500.000 per tahun selama 4 tahun berikutnya. Pada suku bunga 8\% yang diberikan tiap 6 bulan, berapa nilai surat berharga tersebut saat ini?

11. X meminjam sejumlah uang dan akan dibayar sekalugus 10 bulan lagi. Ia menerima Rp.5.200.000,-. Jika suku bunga 11\%, tentukan suku diskonto yang dikenakan dan besarnya pinjaman X. 


\section{\begin{tabular}{l|l} 
Pengantar Matematika Aktuaria & 2018
\end{tabular}}

12. Sebuah perusahaan mebel menerima sebuah bon pembayaran sebesar Rp.1.143.253.000,- yang akan jatuh tempo 30 hari lagi. Jika dibayar dalam 10 hari, maka perusahaan dapat perusahaan akan menerima Rp.1.131.820.000,- Tentukan tingkat bunga sederhana dan tingkat diskon yang digunakan dalam transaksi tersebut.

13. Pada saat kelahiran anaknya, seorang ayah ingin menginvestasikan sejumlah uang agar pada saat anaknya berusia 18 tahun terkumpul uang sebesar Rp.90.000.000,-. Jika ia berinvestasi pada deposito 6 bulan dengan suku bunga 7\%, berapa banyak uang yang mesti ia investasikan?

14. Seorang peminjam ditawari pembayaran (a) Rp.80.000.000,- sekarang atau (b) Rp.143.000.000,- 5 tahun lagi. Jika suku bunga 12\% dibayarkan tiap 6 bulan, pilihan manakah yang lebih menguntungkannya?

15. Sebuah pinjaman sebesar Rp.5.000.000,- yang diberikan 2 tahun lagi dan Rp.7.500.000,- yang diberikan 6 tahun lagi akan dibayar sekaligus pada 4 tahun dari sekarang. Berapa nilai pembayaran tersebut jika suku bunga $12 \%$ dan bunga dibayarkan tiap 3 bulan?

16. Budi membeli surat berharga senilai Rp.150.000.000,- yang bunga majemuk terakumulasi 2 tahunnya akan dibayarkan hari ini. Ia membayar Rp.50.000.000,- tunai dan sisanya setahun lagi. Jika suku bunga $5 \%$ dan pembayaran bunga tiap 3 bulan, tentukan berapa banyak yang mesti ia bayar tahun depan?

17. Jika suku bunga yang digunakan $6 \%$ dan pembayaran tiap 3 bulan, tentukan 4 buah pembayaran tahunan yang sama yang senilai dengan 


\section{Pengantar Matematika Aktuaria 2018}

obligasi seharga Rp.200.000.000,- hari ini jika pembayaran pertama dilakukan
A. hari ini,
B. setahun lagi

18. A meminjamkan uang kepada B sebesar Rp.25.000.000,-. Pinjaman ini akan dibayar B dua tahun lagi sebesar Rp.30.000.000,--

a. Jika bunga dikenakan per 3 bulan, dan suku bunga yang berlaku 15\%, siapakah yang lebih beruntung dengan transaksi tersebut?

b. Dengan bunga dan suku bunga seperti tercantum pada a, kapan seharusnya pinjaman dibayar agar kedua pihak sama-sama diuntungkan?

c. Sama dengan pertanyaan a, jika suku bunga $10 \%$, siapa yang lebih diuntungkan? 


\section{Pengantar Matematika Aktuaria 2018}

BAB III

\section{ANUITAS PASTI}

Transaksi keuangan yang terjadi ada yang berupa transaksi tunggal dan berupa transaksi yang berulang-ulang. Salah satu transaksi berulang yang memiliki karakteristik tertentu adalah anuitas.

\section{Definisi}

Anuitas (Annuity) adalah deretan pembayaran (lebih dari satu kali) dengan periode/jangka waktu yang tetap

Jangka waktu tetap misalnya harian, mingguan, bulanan, kuartalan, semesteran, tahunan, atau lain-lain. Besarnya nilai pembayaran dalam anuitas tidak diharuskan bernilai tetap.

Contohnya adalah:

- pembayaran cicilan kredit

- pembayaran SPP

- pembayaran gaji/pensiun

- $\operatorname{arisan}$

Dalam hal banyaknya pembayaran adalah takhingga, maka hal ini disebut perpetuitas (perpetuity).

Anuitas dibedakan berdasarkan nilai nominal setiap pembayaran, waktu pembayaran, dan kepastian pembayaran. 


\section{Pengantar Matematika Aktuaria 2018}

Berdasarkan nilai nominal setiap pembayaran, anuitas dibedakan menjadi:

1. Anuitas tetap

Pada anuitas ini, nilai nominal setiap pembayaran tetap/konstan.

Misalnya, setiap bulan Rp.500.000,-.

2. Anuitas berubah

Nilai nominal setiap pembayaran pada anuitas ini dapat berubah-ubah

(monoton naik/turun, dll.) sesuai perjanjian. Misalnya, Rp.5.000.000,-

pada tahun I, Rp.10.000.000,- pada tahun II, Rp.15.000.000,- pada tahun III, dst.

Berdasarkan waktu pembayaran, anuitas dibedakan menjadi:

1. Anuitas awal (Annuity-Due):

Pada anuitas ini, waktu pembayaran adalah pada awal setiap periode, misalnya setiap tanggal 1 untuk periode bulanan, atau tanggal 1 Januari untuk periode tahunan.

2. Anuitas akhir (Annuity-Immediate)

Waktu pembayaran anuitas ini adalah pada akhir periode, misalnya tanggal 28/29/30/31 untuk periode bulanan, atau tanggal 31 Desember untuk periode tahunan.

3. Anuitas yang ditunda (Deferred Annuity)

Untuk anuitas ini, pembayaran pertama ditunda beberapa periode. Misalnya, ditunda m periode, tetapi jumlah pembayaran tetap $\mathrm{n}$ kali. 


\section{\begin{tabular}{l|l} 
Pengantar Matematika Aktuaria & 2018
\end{tabular}}

Contohnya pembayaran pada kredit perkebunan ditunda 4 tahun, lalu dibayar cicilannya setiap bulan selama 10 tahun.

Yang perlu menjadi perhatian kita pada waktu pembayaran anuitas ini adalah waktu pembayaran pada akhir suatu periode umumnya disamakan dengan waktu pembayaran pada awal periode berikutnya. Jadi, pembayaran pada tanggal 1 April bisa dikatakan pembayaran anuitas akhir untuk periode bulanan Maret, sama halnya dengan pembayaran pada tanggal 31 Maret.

Berdasarkan kepastian pembayaran, anuitas dibedakan menjadi:

1. Anuitas pasti (Certain Annuity):

Pada anuitas ini, seluruh pembayaran sifatnya adalah pasti (mesti dilakukan), meskipun pihak yang berkewajiban mengalami kendala (meninggal, bencana, atau lain-lain). Dalam konteks teori peluang, peluang terjadinya pembayaran adalah 1 . Contohnya adalah kredit tanpa asuransi (dimana jika yang bersangkutan meninggal, maka pembayaran yang tersisa akan dilakukan oleh ahli warisnya) atau pembayaran pensiun PNS (jika suami meninggal, maka istri masih bisa menerima).

2. Anuitas hidup (Life Annuity)

Pembayaran pada anuitas jenis ini akan berhenti jika yang bersangkutan meninggal. Ada ketidakpastian dalam setiap pembayaran atau, dalam konteks teori peluang, peluang terjadinya pembayaran dari 0 sampai dengan 1 . Contohnya adalah kredit yang 


\section{Pengantar Matematika Aktuaria 2018}

berasuransi, pembayaran premi asuransi, dan pembayaran pensiun non PNS.

Pada bab ini, anuitas yang akan dibahas adalah anuitas pasti dengan nilai pembayaran tetap.

\section{A. Anuitas Awal}

Sebelum menentukan formula untuk anuitas ini, akan diperkenalkan terlebih dahulu lambang-lambang standar yang digunakan, yaitu sebagai berikut:

\footnotetext{
$\mathrm{a}_{\mathrm{n}}$ : nilai sekarang dari anuitas awal sebesar 1 rupiah yang dibayar selama n periode.

$\mathrm{s}_{\mathrm{n}}$ : nilai mendatang (pada akhir perjanjian) dari anuitas awal sebesar 1 rupiah yang dibayar selama n periode.
}

Untuk membentuk persamaan atau formula anuitas ini, perhatikan kasus yang paling sederhana berikut. Misalkan setiap pembayaran adalah sebesar 1 rupiah dan dilakukan selama n kali di awal periode? Pada suku bunga i, berapa nilai sekarang dari semua pembayaran? Berapa pula nilai mendatang (pada akhir perjanjian) dari semua pembayaran?

Pada diagram garis waktu, anuitas awal tadi bisa kita gambarkan sebagai berikut:

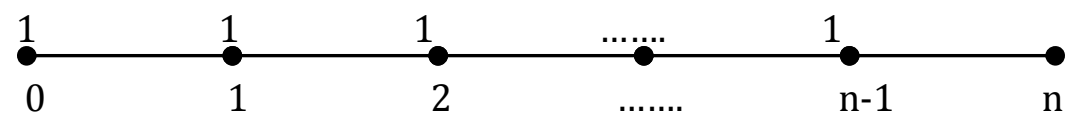




\section{\begin{tabular}{l|l} 
Pengantar Matematika Aktuaria & 2018
\end{tabular}}

Selanjutnya, nilai sekarang dari setiap pembayaran dapat ditabelkan seperti tabel berikut.

Tabel 8. Nilai Sekarang dari Anuitas Awal tiap Periode Pembayaran

\begin{tabular}{|c|c|c|}
\hline Pembayaran & Besar pembayaran & Nilai Sekarang \\
\hline I & 1 & 1 \\
\hline II & 1 & $\mathrm{v}$ \\
\hline III & 1 & $\mathrm{v}^{2}$ \\
\hline$\ldots$ & $\ldots$ & $\ldots$ \\
\hline ke-n & 1 & $\mathrm{v}^{\mathrm{n}}-1$ \\
\hline
\end{tabular}

Jadi, secara kumulatif, nilai sekarang dari semua pembayaran adalah:

$$
a_{n}=1+v+v^{2}+\ldots+v^{n-1}
$$

Perhatikan bahwa ruas kanan merupakan deret geometri yang terdiri dari $\mathrm{n}$ suku, dengan suku pertamanya adalah 1 , dan rasionya adalah v. Karena v $<1$, maka jumlah n suku deret tersebut adalah

$$
a_{n}=\frac{1-v^{n}}{1-v}
$$

Dengan cara sama, kita peroleh persamaan untuk perpetuitas awal

$$
a_{\infty}=\frac{1}{1-v}
$$

Untuk menentukan nilai mendatang dari semua anuitas, perhatikan tabel nilai mendatang dari semua pembayaran tersebut. 


\section{\begin{tabular}{l|l} 
Pengantar Matematika Aktuaria & 2018
\end{tabular}}

Tabel 9. Nilai Mendatang dari Anuitas Awal tiap Periode Pembayaran

\begin{tabular}{|c||c|c|}
\hline Pembayaran & $\begin{array}{c}\text { Besar } \\
\text { pembayaran }\end{array}$ & Nilai Mendatang (pada akhir periode) \\
\hline I & 1 & $(1+\mathrm{i})^{\mathrm{n}}$ \\
\hline II & 1 & $(1+\mathrm{i})^{\mathrm{n}-1}$ \\
\hline III & 1 & $(1+\mathrm{i})^{\mathrm{n}-2}$ \\
\hline$\ldots$ & $\ldots$ & $\ldots$ \\
\hline ke-n & 1 & $1+\mathrm{i}$ \\
\hline
\end{tabular}

Maka, secara kumulatif nilai mendatangnya adalah:

$$
\mathrm{s}_{\mathrm{n}}=(1+\mathrm{i})+(1+\mathrm{i})^{2}+\ldots+(1+\mathrm{i})^{\mathrm{n}}
$$

Perhatikan bahwa ruas kanan juga merupakan deret geometri yang terdiri dari n suku, dengan suku pertamanya adalah $1+\mathrm{i}$, dan rasionya adalah $1+\mathrm{i}$. Akibatnya, dengan menggunakan rumus jumlah berhingga deret dan fakta bahwa $1+\mathrm{i}>1$, kita peroleh formula untuk nilai mendatang adalah

$$
s_{n}=(1+i) \frac{(1+i)^{n}-1}{(1+i)-1}
$$

Contoh penerapan.

1. Seseorang dijanjikan akan menerima uang Rp.20.000.000,- setiap awal tahun selama 10 tahun. Jika semuanya diterima sekarang, berapa nilai yang ekivalen dengan itu pada suku bunga $10 \%$ ?

Jawab.

Diketahui. $\quad \mathrm{i}=0,1$ 


\section{\begin{tabular}{l|l} 
Pengantar Matematika Aktuaria & 2018
\end{tabular}}

$$
\mathrm{n}=10
$$

Persamaan nilai:

Nilai sekarang dari penerimaan $=$ Nilai sekarang dari anuitas

$$
\begin{aligned}
& =R p \cdot 20.000 .000,-a_{10} \\
& =R p \cdot 20.000 .000 \frac{1-v^{10}}{1-v} \\
& =R p \cdot 135.180 .480,-
\end{aligned}
$$

2. Sewaktu kelahiran anaknya, seorang ayah mulai menyimpan tiap 6 bulan sejumlah uang yang sama agar ketika si anak berumur 18 tahun, ia punya uang Rp.250.000.000,- untuk biaya kuliah anak tersebut. Jika simpanan itu memiliki suku bunga $8 \%$ dan bunga diberikan tiap 6 bulan, berapa yang mesti ia simpan tiap awal semester?

Jawab.

Misalkan K adalah besar simpanan tiap 6 bulan

Diketahui. $\quad \mathrm{i}=0,08 / 2=0,04$

$$
\mathrm{n}=36 \text { semester }
$$

Persamaan nilai:

Nilai mendatang dari simpanan $=$ Nilai mendatang dari anuitas

$$
\begin{aligned}
\text { Rp.250.000.000,- } & =K s_{36} \\
& =K(1+0,04) \frac{(1+0,04)^{36}-1}{(1+0,04)-1} \\
K & =\text { Rp.3.097.808,- }
\end{aligned}
$$




\section{Pengantar Matematika Aktuaria 2018}

3. Sebuah sumber mata air alam setiap bulan bisa melayani kebutuhan 1000 tangki air senilai Rp.50.000.000,-- Seorang investor berminat untuk membeli sumber mata air tersebut dari masyarakat setempat. Pada suku bunga $6 \%$ dan asumsi bunga dikenakan tiap bulan, berapakah harga yang harus ditawarkan masyarakat kepada investor tersebut?

Jawab.

Diketahui. $\quad \mathrm{i}=0,06 / 12=0,005$

n takhingga

Persamaan nilai:

Nilai sekarang dari penjualan air = Nilai sekarang dari perpetuitas

$$
\begin{aligned}
& =50.000 .000 \mathrm{a}_{\infty} \\
& =50.000 .000 \frac{1}{1-\mathrm{v}} \\
& =\text { Rp.10.050.000.000,- }
\end{aligned}
$$

\section{B. Anuitas Akhir}

Pada anuitas akhir, notasi yang digunakan adalah:

$a_{n}$ : nilai sekarang dari anuitas akhir sebesar 1 rupiah yang dibayar selama n periode.

$\mathrm{s}_{\bar{n}}$ : nilai mendatang (pada akhir perjanjian) dari anuitas akhir sebesar 1 rupiah yang dibayar selama n periode. 


\section{\begin{tabular}{l|l} 
Pengantar Matematika Aktuaria & 2018
\end{tabular}}

Untuk membentuk persamaan atau formula anuitas ini, pembayaran anuitas sebesar 1 rupiah dan dilakukan selama n tahun di akhir tahun akan meenuhi skema berikut.

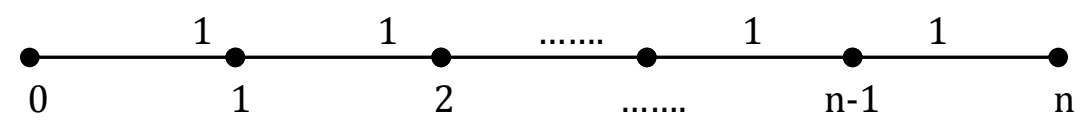

Selanjutnya, nilai sekarang dari setiap pembayaran dapat ditabelkan seperti tabel berikut.

Tabel 10. Nilai Sekarang dari Anuitas Akhir tiap Periode Pembayaran

\begin{tabular}{|c|c|c|}
\hline Pembayaran & Besar pembayaran & Nilai Sekarang \\
\hline I & 1 & $\mathrm{v}$ \\
\hline II & 1 & $\mathrm{v}^{2}$ \\
\hline III & 1 & $\ldots$ \\
\hline$\ldots$ & $\ldots$ & $\mathrm{v}^{\mathrm{n}}-1$ \\
\hline ke-n & 1 & $\mathrm{v}^{\mathrm{n}}$ \\
\hline
\end{tabular}

Jadi, secara kumulatif, nilai sekarang dari semua pembayaran adalah:

$$
\mathrm{a}_{\mathrm{n}}=\mathrm{v}+\mathrm{v}^{2}+\ldots+\mathrm{v}^{\mathrm{n}-1}+\mathrm{v}^{\mathrm{n}}
$$

yang merupakan deret geometri yang terdiri dari n suku, dengan suku pertamanya adalah $\mathrm{v}$, dan rasionya adalah v. Akibatnya, karena $\mathrm{v}<1$, diperoleh

$$
a_{n}=v \frac{1-v^{n}}{1-v}
$$




\section{\begin{tabular}{l|l} 
Pengantar Matematika Aktuaria & 2018
\end{tabular}}

Sementara, dengan cara sama, diperoleh persamaan untuk perpetuitas akhir

$$
\mathrm{a}_{\infty \mathrm{l}}=\frac{\mathrm{v}}{1-\mathrm{v}}=\frac{1}{\mathrm{i}}
$$

Untuk menentukan nilai mendatang dari semua anuitas, perhatikan tabel nilai mendatang dari semua pembayaran tersebut.

Tabel 11. Nilai mendatang dari Anuitas Akhir tiap Periode Pembayaran

\begin{tabular}{|c|c|c|}
\hline Pembayaran & $\begin{array}{c}\text { Besar } \\
\text { pembayaran }\end{array}$ & $\begin{array}{c}\text { Nilai Mendatang } \\
\text { (pada akhir periode) }\end{array}$ \\
\hline I & 1 & $(1+\mathrm{i})^{\mathrm{n}-1}$ \\
\hline II & 1 & $(1+\mathrm{i})^{\mathrm{n}-2}$ \\
\hline III & 1 & $(1+\mathrm{i})^{\mathrm{n}-3}$ \\
\hline$\ldots$ & $\ldots$ & $\ldots$ \\
\hline ke-n & 1 & 1 \\
\hline
\end{tabular}

Maka, secara kumulatif nilai mendatangnya adalah:

$$
\mathrm{s}_{\mathrm{n}}=1+(1+\mathrm{i})+(1+\mathrm{i})^{2}+\ldots+(1+\mathrm{i})^{\mathrm{n}-1}
$$

yang merupakan deret geometri yang terdiri dari $\mathrm{n}$ suku, dengan suku pertamanya adalah 1, dan rasionya adalah 1+i. Akibatnya, dengan menggunakan rumus jumlah berhingga deret dan fakta bahwa $1+i>1$, kita peroleh formula untuk nilai mendatang adalah

$$
\mathrm{s}_{\mathrm{n}}=\frac{(1+\mathrm{i})^{\mathrm{n}}-1}{(1+\mathrm{i})-1}
$$




\section{Pengantar Matematika Aktuaria 2018}

\section{Contoh.}

1. Sebuah rumah dibeli dengan membayar uang muka Rp.50.000.000,- dan cicilan tiap akhir tahun sebesar Rp.20.000.000,- selama 15 tahun. Jika $\mathrm{i}=12 \%$, tentukan nilai tunai rumah sekarang.

Diketahui:

$$
\begin{aligned}
& \mathrm{i}=0,12 \quad \mathrm{v}=0,892857 \\
& \mathrm{n}=15
\end{aligned}
$$

Ditanya

Nilai tunai sekarang

Jawab.

Nilai tunai sekarang = Nilai sekarang uang muka + Nilai sekarang anuitas

$$
\begin{aligned}
& =50.000 .000+20.000 .000 \mathrm{a} \frac{-}{15} \\
& =50.000 .000+20.000 .000 \mathrm{v} \frac{1-v^{15}}{1-\mathrm{v}} \\
& =50.000 .000+20.000 .000(6,810864) \\
& =186.217 .290 .
\end{aligned}
$$

2. Uang sebesar Rp.100.000.000,- diperlukan pada akhir tahun ke-10. Jika uang disediakan dengan secara berangsur pada setiap akhir tahun dan untuk angsuran tersebut diperoleh bunga 5\% per tahun, tentukan besar angsuran yang harus dilakukan.

Diketahui:

$$
\begin{aligned}
& \mathrm{i}=0,05 \\
& \mathrm{n}=10
\end{aligned}
$$




\section{\begin{tabular}{l|l} 
Pengantar Matematika Aktuaria & 2018
\end{tabular}}

Ditanya

Besar angsuran, misalkan A

Jawab.

Nilai tunai mendatang = Nilai mendatang anuitas

$$
\begin{aligned}
& 100.000 .000=\mathrm{As}_{10} \\
& \qquad \begin{aligned}
\mathrm{A} & =100.000 .000: \frac{(1+0,05)^{10}-1}{(1+0,05)-1} \\
& =100.000 .000: 12,57789 \\
& \cong 7.950 .500
\end{aligned}
\end{aligned}
$$

\section{Hubungan anuitas awal dan akhir}

Dengan menggunakan formula yang telah diperoleh untuk nilai sekarang dan nilai mendatang, maka diperoleh hubungan

$$
a_{n}=v \frac{1-v^{n}}{1-v}=v a_{n}
$$

dan

$$
s_{n}=(1+i) \frac{(1+i)^{n}-1}{(1+i)-1}=(1+i) s_{n}
$$

\section{Anuitas yang ditunda.}

Anuitas yang ditunda bisa merupakan anuitas awal atau anuitas akhir. Untuk itu, akan digunakan notasi berikut. 


\section{Pengantar Matematika Aktuaria 2018}

$\left.\mathrm{m}\right|_{\mathrm{n}}$ : nilai sekarang dari anuitas awal sebesar 1 rupiah selama $\mathrm{n}$ periode yang pembayaran pertamanya ditunda m periode.

$\mathrm{m} \mid \mathrm{a}_{\mathrm{n}}$ : nilai sekarang dari anuitas akhir sebesar 1 rupiah selama $\mathrm{n}$ periode yang pembayaran pertamanya ditunda m periode.

Untuk menentukan formula dari anuitas yang ditunda ini, perhatikan ilustrasi untuk anuitas awal yang ditunda berikut.

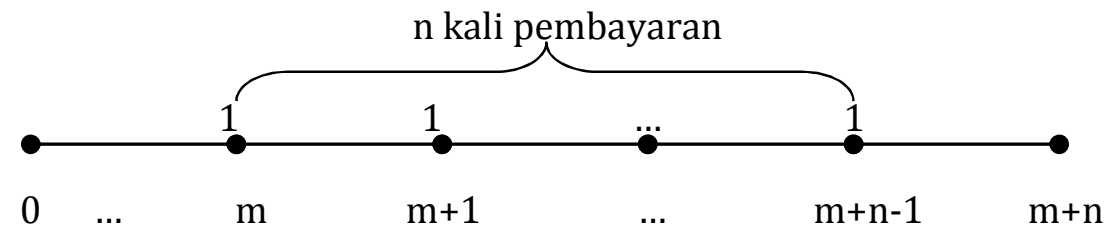

Nilai sekarang dari semua pembayaran dapat kita tabelkan seperti berikut.

Tabel 12. Nilai Sekarang dari Anuitas yang Ditunda tiap Periode Pembayaran

\begin{tabular}{|c|c|c|}
\hline Pembayaran & Besar pembayaran & Nilai Sekarang \\
\hline I & 1 & ${ }^{\mathrm{m}}$ \\
\hline II & 1 & $\mathrm{v}^{\mathrm{m}+1}$ \\
\hline III & 1 & $\mathrm{v}^{\mathrm{m}+2}$ \\
\hline$\ldots$ & $\ldots$ & $\ldots$ \\
\hline ke-n & 1 & $\mathrm{v}^{\mathrm{m}+\mathrm{n}-1}$ \\
\hline
\end{tabular}

Maka, kita peroleh formulasi berikut

$$
\mathrm{m} \mid \mathrm{a}_{\mathrm{n}}=\mathrm{v}^{\mathrm{m}}+\mathrm{v}^{\mathrm{m}+1}+\ldots+\mathrm{v}^{\mathrm{m}+\mathrm{n}-1}
$$

yang bisa disederhanakan menjadi

$$
\mathrm{m} \mid \mathrm{a}_{\mathrm{n} \mid}=\mathrm{v}^{\mathrm{m}} \frac{1-\mathrm{v}^{\mathrm{n}}}{1-\mathrm{v}} \quad \text { atau } \mathrm{a}_{\mathrm{n}}=\mathrm{v}^{\mathrm{m}} \mathrm{a}_{\mathrm{n}}
$$




\section{\begin{tabular}{l|l} 
Pengantar Matematika Aktuaria & 2018
\end{tabular}}

Dengan cara yang sama, nilai anuitas akhir yang ditunda akan memenuhi formulasi

$$
\mathrm{m} \mid \mathrm{a}_{\mathrm{n} \mid}=\mathrm{v}^{\mathrm{m}} \mathrm{a}_{\mathrm{n}}=\mathrm{v}^{\mathrm{m}}\left(\mathrm{v} \frac{1-\mathrm{v}^{\mathrm{n}}}{1-\mathrm{v}}\right)
$$

\section{Contoh.}

Perusahaan real-estate menawarkan kepada anda beberapa pilihan untuk pembayaran sebuah rumah berikut:

a. Uang muka Rp.104.000.000,- dan cicilan Rp.52.000.000,- per tahun selama 8 tahun.

b. Tunai Rp.130.000.000,- dan Rp.260.000.000,- tahun berikutnya.

c. Cicilan Rp.53.250.000,- per tahun selama 15 tahun mulai saat ini.

Jika suku bunga diperkirakan selama beberapa tahun tersebut stabil sekitar $12 \%$, pilihan mana yang akan anda pilih?

Jawab.

Diketahui:

$$
\mathrm{i}=12 \%=0,12 \quad \mathrm{v}=0,892857143
$$

a. Nilai sekarang dari rumah $=104.000 .000+52.000 .000 \mathrm{a}_{8}$

$$
=\text { Rp.362.317.268,- }
$$

b. Nilai sekarang dari rumah $=130.000 .000+260.000 .000 \mathrm{v}$

$$
=\text { Rp. 362.142.857,- }
$$

c. Nilai sekarang dari rumah $=47.500 .000 \mathrm{a}_{15}=\mathrm{Rp} .362 .337 .991,-$ Jadi, pilihan terbaik adalah pilihan $b$. 


\section{\begin{tabular}{l|l} 
Pengantar Matematika Aktuaria & 2018
\end{tabular}}

\section{Anuitas dengan Pembayaran m Kali Ssetahun.}

\section{Anuitas awal}

Misalkan pembayaran di awal tahun sebesar 1 rupiah bisa dilakukan m kali setahun. Maka nilai pembayaran itu akan sama dengan $1 /$ m setiap pembayaran. Ingat, bunga yang dibayar mesti sama. Akibatnya, suku bunga i menjadi suku bunga efektif. Dengan persamaan nilai kita peroleh

$$
\begin{aligned}
& P(1+i)=P\left(1+\frac{i^{(m)}}{m}\right)^{m} \\
& i^{(m)}=m\left[(1+i)^{\frac{1}{m}}-1\right]
\end{aligned}
$$

Pandang gambar garis waktu untuk 1 tahun

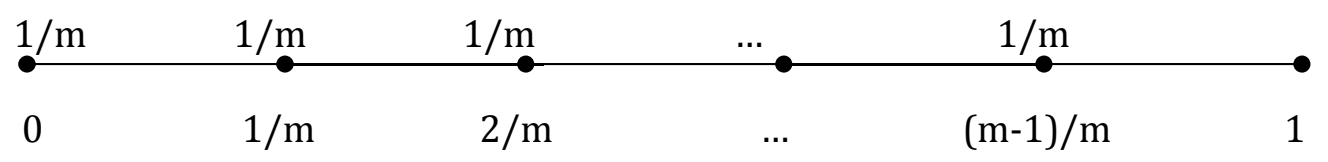

Selanjutnya, perhatikan tabel berikut:

Tabel 13. Nilai sekarang dari Anuitas Awal dengan m pembayaran per tahun

\begin{tabular}{|c|c|c|}
\hline Pembayaran & Besar pembayaran & Nilai Sekarang \\
\hline I & $1 / \mathrm{m}$ & $1 / \mathrm{m}$ \\
\hline II & $1 / \mathrm{m}$ & $\mathrm{v}^{1 / \mathrm{m}}$ \\
\hline III & $1 / \mathrm{m}$ & $\mathrm{v}^{2 / \mathrm{m}}$ \\
\hline$\ldots$ & $\ldots$ & $\cdots$ \\
\hline $\mathrm{ke}-\mathrm{m}$ & $1 / \mathrm{m}$ & $\mathrm{v}^{\mathrm{m}-1 / \mathrm{m}}$ \\
\hline
\end{tabular}




\section{\begin{tabular}{l|l} 
Pengantar Matematika Aktuaria & 2018
\end{tabular}}

Misalkan nilai sekarang dari semua anuitas tsb, dilambangkan dengan $\mathrm{a}_{\overline{\mathrm{n}} \mid}^{(\mathrm{m})}$ maka diperoleh

$$
a_{\bar{n} \mid}^{(m)}=\frac{1}{m}+\frac{1}{m} v^{1 / m}+\frac{1}{m} v^{2 / m}+\ldots+\frac{1}{m} v^{(n m-1) / m}
$$

Yang merupakan deret geometri dengan $\mathrm{nm}$ suku, suku pertama 1/m, dan $\operatorname{rasio} \mathrm{v}^{1 / \mathrm{m}}$.

Akibatnya, karena $\mathrm{v}^{1 / \mathrm{m}}<1$, diperoleh

$$
a_{\bar{n}}^{(m)}=\frac{1}{m} \frac{1-v^{n}}{1-v^{1 / m}}
$$

Selanjutnya, karena

$$
\mathrm{m}\left(1-\mathrm{v}^{1 / \mathrm{m}}\right)=\mathrm{m}\left(1-\frac{1}{(1+\mathrm{i})^{1 / \mathrm{m}}}\right)=\frac{\mathrm{m}\left[(1+\mathrm{i})^{1 / \mathrm{m}}-1\right]}{(1+\mathrm{i})^{1 / \mathrm{m}}}=\frac{\mathrm{i}^{(\mathrm{m})}}{\mathrm{v}^{1 / \mathrm{m}}}
$$

maka diperoleh

$$
\mathrm{a}_{\overline{\mathrm{n}} \mid}^{(\mathrm{m})}=\frac{\mathrm{i}^{(\mathrm{m})}}{m v^{1 / \mathrm{m}}}
$$

\section{Anuitas akhir}

Dengan cara yang sama, kita peroleh nilai sekarang dari anuitas akhir yang dilakukan m kali setahun adalah

$$
\mathrm{a}_{\overline{\mathrm{n}} \mid}^{(\mathrm{m})}=\frac{1-\mathrm{v}^{\mathrm{n}}}{\mathrm{i}^{(\mathrm{m})}}
$$




\section{\begin{tabular}{l|l} 
Pengantar Matematika Aktuaria & 2018
\end{tabular}}

\section{E. Aplikasi dari Anuitas}

\section{Amortisasi}

Amortisasi adalah jenis pinjaman yang dibayar melalui suatu deretan pembayaran dengan nilai dan jangka waktu tetap dimana setiap pembayaran memuat bagian pembayaran pokok pinjaman dan bagian bunga. Misalkan: kredit rumah, kendaraan, dll.

Untuk kepentingan akuntansi dibuatkan Tabel Amortisasi yang menampilkan porsi pokok dan bunga dari setiap pembayaran (biasanya dimulai dari pembayaran pertama). Tabel ini menampilkan periode pembayaran, sisa pinjaman saat itu, bunga yang dibayarkan, nilai setiap pembayaran, dan akumulasi pembayaran pinjaman sampai dengan saat itu.

Untuk itu, dalam mengisi tabel akan diperlukan notasi dan perhitungan berikut.

Misalkan

$$
\begin{aligned}
& \mathrm{b}_{0} \text { : nilai pinjaman } \\
& \mathrm{b}_{\mathrm{k}} \text { : nilai pinjaman setelah pembayaran ke-k } \\
& \mathrm{i} \text { : suku bunga pinjaman } \\
& \mathrm{P} \text { : nilai pembayaran setiap periode }
\end{aligned}
$$

Maka bagian bunga pada pembayaran ke-k adalah:

$\mathrm{ib}-1$

Dan bagian pokok pada pembayaran ke-k adalah

$$
\mathrm{P}-\mathrm{i} b_{\mathrm{k}-1}
$$




\section{Pengantar Matematika Aktuaria 2018}

Perhatikan juga bahwa

$b_{k+1}=(1+i) b_{k}-P$

\section{Menentukan Outstanding Loan (Sisa Pinjaman ) dengan Metode Prospektif dan Retrospektif}

Ada dua metode yang digunakan untuk menghitung sisa pinjaman pada setiap periode, yaitu metode prospektif dan retrospektif. Penjelasannya adalah sebagai berikut.

1. Pada metode prospektif, sisa pinjaman pada setiap periode dipandang sebagai nilai sekarang dari sisa pembayaran

$$
\mathrm{b}_{\mathrm{k}}=\mathrm{Pa} \frac{\mathrm{n}-\mathrm{k}}{\mathrm{n}}
$$

Persamaan ini diperoleh dengan cara sebagai berikut:

Pandang persamaan nilai pinjaman pada tahun pertama

$$
\mathrm{b}_{0}=\mathrm{Pa}
$$

dan pada akhir tahun I

$$
\begin{aligned}
b_{1} & =b_{0}(1+i)-P \\
& =P a_{n}(1+i)-P \\
& =P\left(v \frac{1-v^{n}}{1-v}\right)(1 / v)-P \\
& =P\left(\frac{1-v^{n}}{1-v}\right)-P
\end{aligned}
$$




\section{\begin{tabular}{l|l} 
Pengantar Matematika Aktuaria & 2018
\end{tabular}}

$$
\begin{aligned}
& =P\left(\frac{1-v^{n}}{1-v}-1\right) \\
& =P\left(\frac{1-v^{n}}{1-v}-\frac{1-v}{1-v}\right) \\
& =P \frac{v-v^{n}}{1-v} \\
& =P v \frac{1-v^{n-1}}{1-v} \\
& =P a \frac{1}{n-1}
\end{aligned}
$$

sehingga pada periode ke-k sisa pinjaman adalah sebesar

$$
\mathrm{b}_{\mathrm{k}}=\mathrm{P} \mathrm{a}_{\mathrm{n}-\mathrm{k}}
$$

2. Sementara pada metode retrospektif, sisa pinjaman pada setiap periode dipandang sebagai nilai akumulasi pinjaman dikurangi nilai akumulasi pembayaran yang telah dilakukan

$$
\mathrm{b}_{\mathrm{k}}=\mathrm{b}_{0}(1+\mathrm{i})^{\mathrm{k}}-\mathrm{Ps}_{\mathrm{k}}
$$

Persamaan ini diperoleh dengan cara sebagai berikut:

Pandang persamaan nilai pinjaman pada akhir tahun I

$$
b_{1}=b_{0}(1+i)-P
$$

dan pada akhir tahun II

$$
\begin{aligned}
b_{2} & =b_{1}(1+i)-P \\
b_{2} & =b_{0}(1+i)^{2}-P(1+i)-P \\
& =b_{0}(1+i)^{2}-P[(1+i)+1]
\end{aligned}
$$




\section{\begin{tabular}{l|l} 
Pengantar Matematika Aktuaria & 2018
\end{tabular}}

$$
\begin{aligned}
& =b_{0}(1+i)^{2}-P\left(\frac{(1+i)^{2}-1}{i}\right) \\
& =b_{0}(1+i)^{2}-P s_{\overline{2}}
\end{aligned}
$$

sehingga pada akhir tahun ke-k, sisa pinjaman adalah sebesar

$$
b_{k}=b_{0}(1+i)^{k}-P s_{k}
$$

Besarnya pembayaran bunga pada periode ke-k adalah $P\left(1-\mathrm{v}^{\mathrm{n}-\mathrm{k}+1}\right)$ sehingga pinjaman terbayar pada periode ke-k adalah $\mathrm{P}-\mathrm{P}\left(1-\mathrm{v}^{\mathrm{n}-\mathrm{k}+1}\right)=\mathrm{Pv}^{\mathrm{n}-\mathrm{k}+1}$.

\section{Contoh}

Seseorang membeli satu blok apartemen "Semangi" seharga Rp.700.000.000,- dengan amortisasi pada suku bunga 20\% selama 10 tahun. Buatkanlah tabel amortisasinya.

Jawab.

Pertama, tentukan besarnya setiap pembayaran tahunan. Misalkan pembayaran tahunan adalah sebesar P.

Selanjutnya, gunakan persamaan nilai

$$
\begin{aligned}
& \text { Nilai Sekarang Apartemen (Pinjaman) = Nilai sekarang anuitas } \\
& \text { 700.000.000,- }=\mathrm{P} \mathrm{a}_{10} \\
& \text {... } \\
& P=166.965 .930,-
\end{aligned}
$$




\section{\begin{tabular}{l|l} 
Pengantar Matematika Aktuaria & 2018
\end{tabular}}

Tabel 14. Tabel Amortisasi

\begin{tabular}{|c|r|r|r|r|}
\hline Periode & Sisa Pinjaman & Bunga & Pembayaran & $\begin{array}{l}\text { Pinjaman } \\
\text { Terbayar }\end{array}$ \\
\hline 1 & $700,000,000$ & $140,000,000$ & $166,965,930$ & $26,965,930$ \\
\hline 2 & $673,034,070$ & $134,606,814$ & $166,965,930$ & $32,359,116$ \\
\hline 3 & $640,674,954$ & $128,134,991$ & $166,965,930$ & $38,830,939$ \\
\hline 4 & $601,844,015$ & $120,368,803$ & $166,965,930$ & $46,597,127$ \\
\hline 5 & $555,246,888$ & $111,049,378$ & $166,965,930$ & $55,916,552$ \\
\hline 6 & $499,330,335$ & $99,866,067$ & $166,965,930$ & $67,099,863$ \\
\hline 7 & $432,230,472$ & $86,446,094$ & $166,965,930$ & $80,519,836$ \\
\hline 8 & $351,710,637$ & $70,342,127$ & $166,965,930$ & $96,623,803$ \\
\hline 9 & $255,086,834$ & $51,017,367$ & $166,965,930$ & $115,948,563$ \\
\hline 10 & $139,138,271$ & $27,827,654$ & $166,965,930$ & $139,138,276$ \\
\hline & & $\mathbf{9 6 9 , 6 5 9 , 2 9 5}$ & $\mathbf{1 , 6 6 9 , 6 5 9 , 3 0 0}$ & $\mathbf{7 0 0 , 0 0 0 , 0 0 5}$ \\
\hline
\end{tabular}

\section{Sinking Fund (Dana Pelunasan/Dana Endapan)}

Sinking Fund adalah cara melunasi pinjaman dimana deretan pembayaran hanya dilakukan untuk membayar bunga, sementara pokok dibayar sekaligus pada akhir perjanjian/transaksi. Dalam hal ini, peminjam mengumpulkan dana sendiri untuk membayar pokok tsb. yang disebut sinking fund (biasanya difasilitasi pemberi pinjaman/bank).

\section{Contoh}

Misalkan pembeli apartemen seharga Rp.700.000.000,- tadi membeli dengan cara meminjam pada BNI pada suku bunga $15 \%$ selama 10 tahun dimana cicilan hanya dilakukan untuk membayar bunga, sementara pokok dibayar pada akhir tahun ke-10. Untuk itu, BNI menyediakan dana endapan dengan suku bunga 10\%. Tentukan 


\section{\begin{tabular}{l|l} 
Pengantar Matematika Aktuaria & 2018
\end{tabular}}

besarnya nilai setiap simpanan yang mesti dilakukan orang tersebut

pada dana endapan dan buatkan tabel sinking fund-nya

\section{Jawab.}

Diketahui:

$$
\begin{aligned}
& \mathrm{i}=0,1 \\
& \mathrm{n}=10
\end{aligned}
$$

Misalkan nilai setiap pembayaran P.

Nilai mendatang sinking fund $=$ Nilai pinjaman

$$
\mathrm{Ps}_{10}=700.000 .000,-
$$

$$
P=39.928 .900,-
$$

Tabel 15. Tabel Sinking Fund

\begin{tabular}{|c|c|c|c|c|}
\hline Periode & Simpanan & $\begin{array}{c}\text { Nilai } \\
\text { Akumulasi }\end{array}$ & \multicolumn{1}{c|}{ Bunga } & Dana Endapan \\
\hline 1 & $39,928,900$ & $39,928,900$ & $3,992,890$ & $43,921,790$ \\
\hline 2 & $39,928,900$ & $83,850,690$ & $8,385,069$ & $92,235,759$ \\
\hline 3 & $39,928,900$ & $132,164,659$ & $13,216,466$ & $145,381,125$ \\
\hline 4 & $39,928,900$ & $185,310,025$ & $18,531,002$ & $203,841,027$ \\
\hline 5 & $39,928,900$ & $243,769,927$ & $24,376,993$ & $268,146,920$ \\
\hline 6 & $39,928,900$ & $308,075,820$ & $30,807,582$ & $338,883,402$ \\
\hline 7 & $39,928,900$ & $378,812,302$ & $37,881,230$ & $416,693,532$ \\
\hline 8 & $39,928,900$ & $456,622,432$ & $45,662,243$ & $502,284,676$ \\
\hline 9 & $39,928,900$ & $542,213,576$ & $54,221,358$ & $596,434,933$ \\
\hline 10 & $39,928,900$ & $636,363,833$ & $63,636,383$ & $700,000,216$ \\
\hline
\end{tabular}




\section{Pengantar Matematika Aktuaria 2018}

\section{F. Latihan}

1. Buktikan
a. $\mathrm{a}_{\mathrm{n}}=\frac{1-\mathrm{v}^{\mathrm{n}}}{\mathrm{d}}$
b. $a_{n}=v a_{n-1}+v^{n}$
c. $\quad \mathrm{ia}_{\mathrm{n}}=1+\mathrm{i}-\mathrm{v}^{\mathrm{n}-1}$
d. $\quad a_{3 n}=a \frac{1 n}{2 n}+v^{2 n} a_{n}$
e. $\frac{1}{\mathrm{~s}_{\mathrm{n}}}=\frac{1}{\mathrm{a}_{\mathrm{n}}}-\mathrm{d}$
f. $\quad a_{m+n}=a_{m}+\frac{a_{n}}{(1+i)^{m}}$
g. $\quad \mathrm{s}_{\overline{\mathrm{n}+1}}=\mathrm{s}_{\mathrm{n}}+\mathrm{d}+\mathrm{v}$

2. Ahmad menyimpan uang Rp.600.000,- setiap tiga bulan pada sebuah investasi bersuku bunga nominal 12\% yang diberikan tiap 3 bulan. Berapa uangnya setelah 10 tahun?

3. Diperkirakan sebuah perkebunan dapat menghasilkan Rp.150.000.000,tiap tahun selama 10 tahun ke depan dan kemudian tanahnya dapat dijual seharga Rp.100.000.000,- pada waktu itu. Jika suku bunga diperkirakan 8\%, tentukan nilai perkebunan tersebut sekarang.

4. $\mathrm{Bu}$ Siti membeli mesin cuci secara kredit selama tiga tahun. Ia ditawarkan dua jenis pembayaran:

a. Uang muka Rp.500.000,- dan cicilan Rp.1.000.000,- per tahun yang bisa dibayar tiap tiga bulan. 


\section{\begin{tabular}{l|l} 
Pengantar Matematika Aktuaria & 2018
\end{tabular}}

b. Cicilan bulanan sebesar Rp.100.000,- tanpa uang muka.

Pada suku bunga 15\%, manakah pilihan yang lebih ekonomis?

5. Yono menyimpan uang Rp.500.000,- setiap 6 bulan mulai tanggal 1 Februari 2010 sampai tanggal 1 Februari 2017 pada sebuah tabungan bunga harian bersuku bunga nominal 8\%. Cukupkah uangnya Rp.10.000.000,- pada tanggal 1 Agustus 2017? Berapa kelebihan/kekurangannya?

6. Seseorang membeli sebuah peternakan dengan membayar tunai Rp.100.000.000,- dan Rp.20.000.000,- tiap akhir 6 bulan selama 10 tahun. Jika suku bunga $10 \%$ dan dikenakan tiap 3 bulan, berapa nilai tunai peternakan itu?

7. Mahfud membeli sebuah anuitas yang akan memberikan Rp.3.000.000,tiap akhir tiga bulan seharga Rp.90.000.000,-. Pada suku bunga 6\%, berapa kali penerimaan penuh yang ia terima dan berapa nilai pembayaran takpenuh terakhir yang ia terima untuk mengakhiri anuitas tersebut?

8. Sebuah iklan perusahaan sebesar Rp.175.620.000,- harus dibayar dalam 36 bulan sebesar Rp.7.000.000,-perbulan. Tentukan suku bunga nominal dan efektif yang dikenakan.

9. Berapa uang yang mesti disimpan pada tanggal 1 Februari 1995 pada sebuah tabungan bersuku bunga 8\% (majemuk tiap 6 bulan) supaya setiap 6 bulan dapat menarik uang Rp.5.000.000,- mulai tanggal 1 Februari 2005 sampai 1 Agustus 2015? 


\section{\begin{tabular}{l|l} 
Pengantar Matematika Aktuaria & 2018
\end{tabular}}

10. Ani ingin mempunyai uang Rp.75.000.000,- dari sebuah simpanan bersuku bunga $8 \%$ yang diberikan tiap 3 bulan dengan melakukan setoran dengan jumlah Rp.2.000.000,- setiap 3 bulan.

a. Berapa kali ia melakukan setoran penuh?

b. Berapa nilai setoran tambahan yang ia lakukan untuk melengkapi nilai uangnya menjadi Rp.75.000.000,- jika setoran tambahan itu dilakukan pada penyetoran terakhir?

c. Berapa nilai setoran tambahan jika dilakukan 3 bulan setelah setoran terakhir?

11. Seorang pencipta lagu hits ditawari tiga pilihan pembayaran royalti sebuah lagu, yaitu:

a. Dibeli secara tunai Rp.200.000.000,-

b. Dibayar Rp.50.000.000,- setiap tahun selama 5 kali mulai tahun depan.

c. Dibayar Rp.47.500.000,- setiap tahun selama 8 kali dimulai 5 tahun lagi.

d. Dibayar Rp.27.500.000,- setiap tahun selama 10 kali mulai hari ini. Pada suku bunga $8 \%$ p.a., pilihan mana yang anda sarankan?

12. Untuk novelnya yang terbaru, seorang penulis terkenal ditawari beberapa alternatif pembayaran royalti sebagai berikut:

a. Dibayar Rp.150.000.000,- hari ini dan Rp.350.000.000,- lima tahun lagi. 


\section{Pengantar Matematika Aktuaria 2018}

b. Dibayar Rp.110.000.000,- setiap tahun selama 5 kali dimulai 3 tahun lagi.

c. Dibayar Rp.57.000.000,- setiap tahun selama 10 kali mulai tahun depan.

Pada suku bunga 7\% p.a., pilihan mana yang anda sarankan?

13. Buatkanlah tabel amortisasi untuk pembelian sebuah mobil seharga Rp.260.000.000,- dengan uang muka Rp.100.000.000,- dan jangka waktu amortisasi 3 tahun pada suku bunga 18\%. Selanjutnya, tunjukkan kebenaran tabel yang dibuat dengan menghitung secara prospektif dan retrospektif, sisa pinjaman pada periode ke-13 $\left(\mathrm{b}_{13}\right)$. 


\section{Pengantar Matematika Aktuaria 2018}

\section{BAB IV}

\section{TABEL MORTALITAS}

\section{A. Dasar-dasar Teori Peluang}

Salah satu topik dalam aktuaria adalah asuransi dimana salah satu aspeknya adalah uang pertanggungan (benefit) hanya akan dibayarkan jika sesuatu terjadi pada jangka waktu tertentu. Misalnya, sebuah klaim asuransi mobil akan dibayarkan jika terjadi kecelakaan yang melibatkan mobil yang diasuransikan. Kejadian itu dapat dianggap acak. Pada bagian ini, akan diberikan tinjauan singkat mengenai materi-materi pokok teori peluang yang akan digunakan dalam materi aktuaria selanjutnya. Hampir semua materi seharusnya sudah cukup dikenal karena sudah didapatkan dalam matakuliah-matakuliah awal statistika.

Objek utama dalam teori peluang adalah ruang sampel $S$ yang pada hakekatnya sebuah himpunan. Himpunan ini dipandang sebagai koleksi dari semua titik sampel yang mungkin terjadi dari suatu percobaan/pengamatan acak. Subhimpunan dari S, disebut kejadian, diberikan ukuran peluang yang biasanya dilambangkan dengan P. Secara teoritis sederhana, peluang suatu kejadian $\mathrm{K}$ dalam ruang sampel $\mathrm{S}$ dihitung dengan membandingkan jumlah anggota, yang berarti banyaknya kemungkinan $\mathrm{K}$ terjadi, dengan anggota $\mathrm{S}$, yaitu $P(K)=n(K) / n(S)$. 


\section{\begin{tabular}{l|l} 
Pengantar Matematika Aktuaria & 2018
\end{tabular}}

\section{Contoh :}

1. Pada percobaan sebuah koin yang ditos, maka titik sampel yang mungkin didapat adalah munculnya muka atau belakang koin sehingga ruang sampel untuk percobaan tersebut adalah

$$
\mathrm{S}=\{\text { muka, belakang }\}
$$

a. Jika K1 adalah kejadian munculnya muka, maka

$$
P(K 1)=n(K 1) / n(S)=1 / 2 .
$$

b. Jika K2 adalah kejadian munculnya muka dan belakang koin sekaligus, maka $P(K 2)=n(K 2) / n(S)=0 / 2=0$

2. Peluang terambilnya kelereng berwarna hijau pada pengambilan tunggal dari sebuah kotak berisi 2 kelereng hijau dan 9 kelereng kuning adalah 2/11. Hal ini diperoleh dari banyaknya anggota kejadian hijau adalah 2, sementara ruang sampelnya adalah 11 kelereng.

Fungsi peluang memenuhi sifat-sifat berikut:

Misalkan S ruang sampel; A dan B adalah kejadian dalam suatu percobaan. Maka, hal-hal berikut ini berlaku.

1. $0 \leq \mathrm{P}(\mathrm{A}) \leq 1$.

2. $\mathrm{P}(\varnothing)=0$ dan $\mathrm{P}(\mathrm{S})=1$.

3. $\mathrm{P}\left(\mathrm{A}^{\mathrm{C}}\right)=1-\mathrm{P}(\mathrm{A})$

Dalam hal ini, $\mathrm{A}^{\mathrm{C}}$ melambangkan tidak terjadinya kejadian A.

4. $P(A \cup B)=P(A)+P(B)-P(A \cap B)$ 


\section{\begin{tabular}{l|l} 
Pengantar Matematika Aktuaria & 2018
\end{tabular}}

$A \cup B$ melambangkan terjadinya $A$ atau $B$, sedangkan $A \cap B$ melambangkan terjadinya A dan B sekaligus.

5. Jika $A \subseteq B$, maka $P(A) \leq P(B)$

6. $\mathrm{P}(\mathrm{A} \mid \mathrm{B})=\mathrm{P}(\mathrm{A} \cap \mathrm{B}) / \mathrm{P}(\mathrm{B})$

A|B melambangkan terjadinya A jika B telah terjadi.

\section{Kejadian yang saling lepas (mutually exclusive) dan saling bebas (independent).}

Dua kejadian dikatakan saling lepas (mutually exclusive) jika tidak lebih dari satu kejadian dapat terjadi dalam satu kali percobaan. Dengan kata lain, kedua kejadian tidak bisa terjadi sekaligus atau bersamaan. Misalnya, dalam pengambilan satu kartu dari satu pak (52 buah) kartu, kejadian terambilnya kartu as dan terambilnya kartu raja adalah saling lepas. Dalam asuransi jiwa, kematian seorang individu juga dasumsikan saling lepas dengan kejadian meninggalnya individu lain.

Jika A dan $B$ adalah kejadian saling lepas, maka $P(A \cap B)=0$. Akibatnya, sesuai sifat peluang gabungan sebelumnya, akan diperoleh

$$
P(A \cup B)=P(A)+P(B)
$$

Keadaan dimana satu kejadian tidak mempengaruhi/mengubah peluang kejadian lainnya ini dalam statistika disebut kejadian yang saling bebas (independent). Dalam asuransi, pada umumnya kematian seseorang tidak akan mempengaruhi peluang kematian orang lain. 


\section{\begin{tabular}{l|l} 
Pengantar Matematika Aktuaria & 2018
\end{tabular}}

Konsekuensi dari kejadian saling bebas adalah $\mathrm{P}(\mathrm{A} \mid \mathrm{B})=\mathrm{P}(\mathrm{A})$. Selanjutnya, sesuai sifat peluang bersyarat sebelumnya, menimbulkan teorema berikut.

\section{Teorema}

Jika A dan B kejadian yang saling bebas, maka berlaku:

$$
\mathrm{P}(\mathrm{A} \cap \mathrm{B})=\mathrm{P}(\mathrm{A}) \cdot \mathrm{P}(\mathrm{B})
$$

\section{Contoh}

Peluang Adi meninggal dalam tahun ini adalah 0,02, sementara peluang Budi meninggal 0,05. Misalkan A kejadian Adi meninggal dan B kejadian Budi meninggal tahun ini. Jika kita ingin menghitung peluang Adi masih hidup jika Budi meninggal, maka kita peroleh melalui

$$
\mathrm{P}\left(\mathrm{A}^{\mathrm{C}} \mid \mathrm{B}\right)=\mathrm{P}\left(\mathrm{A}^{\mathrm{C}}\right)=1-0,02=0,98 \text {. }
$$

Jika kita ingin menghitung peluang tepat satu yang masih hidup, maka kita peroleh melalui

$$
\begin{aligned}
\mathrm{P}\left[\left(\mathrm{A}^{\mathrm{C}} \cap \mathrm{B}\right) \cup\left(\mathrm{A} \cap \mathrm{B}^{\mathrm{C}}\right)\right] & =\mathrm{P}\left(\mathrm{A}^{\mathrm{C}} \cap \mathrm{B}\right)+\mathrm{P}\left(\mathrm{A} \cap \mathrm{B}^{\mathrm{C}}\right) \\
= & \mathrm{P}\left(\mathrm{A}^{\mathrm{C}}\right) \times \mathrm{P}(\mathrm{B})+\mathrm{P}(\mathrm{A}) \times \mathrm{P}\left(\mathrm{B}^{\mathrm{C}}\right) \\
= & 0,98(0,05)+0,02(0,95) \\
= & 0,068 .
\end{aligned}
$$




\section{\begin{tabular}{l|l} 
Pengantar Matematika Aktuaria & 2018
\end{tabular}}

\section{Peubah Acak}

Konsep dasar yang lain adalah peubah acak. Suatu peubah acak adalah fungsi yang domainnya adalah ruang sampel dari percobaan acak dan rangenya adalah bilangan real. Dalam prakteknya, ruang sampel terabaikan dan orang dengan mudah mengenali peubah acak yang diamatinya. Ketika peubah acak sudah dikenali, orang mungkin bertanya tentang nilai dan peluang yang berkaitan dengan peubah acak tersebut. Semua informasi tentang peluang tersebut ditemukan dalam fungsi distribusi dari peubah acak.

Fungsi distribusi dari peubah acak $\mathrm{X}$, dinyatakan sebagai $\mathrm{F}_{\mathrm{X}}(\mathrm{t})$ didefinisikan sebagai $\mathrm{F}_{\mathrm{X}}(\mathrm{t})=\mathrm{P}(\mathrm{X} \leq \mathrm{t})$. Dua jenis peubah acak adalah diskrit dan kontinu. Suatu peubah acak X dengan fungsi distribusi $F_{X}$ dikatakan diskrit jika $F_{X}$ konstan kecuali pada sejumlah terhitung titik. X dikatakan kontinu jika

$$
F_{X}(t)=\int_{-\infty}^{t} \frac{d}{d s} F_{X}(s) d s
$$

untuk semua bilangan real $\mathrm{t}$.

Fungsi distribusi ini memiliki sifat:

1. $0 \leq \mathrm{FX}_{\mathrm{X}}(\mathrm{t}) \leq 1$.

2. Monoton takturun, artinya jika $s \leq t$, maka $F_{X}(s) \leq F_{X}(t)$.

3. $\lim _{t \rightarrow-\infty} F_{X}(t)=0 \quad \lim _{\text {dan }} F_{X}(t)=1$ 


\section{Pengantar Matematika Aktuaria 2018}

Jika X peubah acak diskrit, kepadatan atau fungsi padat peluang dari X yang

dinyatakan sebagai $f_{X}(t)$ didefinisikan sebagai $f_{X}(t):=P(X=t)$. Sementara jika $\mathrm{X}$ peubah acak kontinu, maka

$$
f_{X}(t)=\frac{d}{d t} F_{X}(t)
$$

Contoh

1. Peubah acak Bernoulli adalah peubah acak yang hanya mempunyai nilai 0 atau 1 . Peubah acak ini biasanya muncul dalam masalah berhasil atau gagalnya sesuatu. Peubah acak ini diskrit.

2. Peubah acak eksponensial $\mathrm{Y}$ dengan parameter $\lambda>0$ adalah peubah acak taknegatif dimana $\mathrm{P}(\mathrm{Y} \geq \mathrm{t})=\mathrm{e}^{-\lambda \mathrm{t}}$ untuk $\mathrm{t}>0$. Peubah acak ini biasanya digunakan untuk memodelkan waktu tunggu sampai suatu kejadian tertentu terjadi. Peubah acak ini kontinu.

\section{Ekspektasi}

Misalkan peluang suatu kejadian terjadi adalah P. sementara nilai yang diperoleh di kejadian tersebut $\mathrm{M}$, maka ekspektasi nilai kejadian itu adalah PM.

Contoh.

Seseorang akan menerima 500 rupiah, jika muncul muka dalam pelemparan koin, maka ekspetasi uang yang diperoleh dari pelemparan koin tersebut adalah $1 / 2 \times 500=250$. 


\section{\begin{tabular}{l|l} 
Pengantar Matematika Aktuaria & 2018
\end{tabular}}

Pada peubah acak, ekspektasi untuk peubah acak diskrit didefinisikan sebagai

$$
E(X)=\sum_{t} t f_{X}(t)
$$

sementara untuk peubah acak kontinu,

$$
E(X)=\int_{-\infty}^{\infty} t f_{X}(t) d t
$$

\section{Contoh}

1) Misalkan peluang Amir meninggal dalam tahun ini adalah 0,7 dan peluang Bakri meninggal dalam tahun ini adalah 0,9. Berapakah peluang:

a) Keduanya masih hidup tahun depan?

b) Tepat satu dari mereka sudah meninggal tahun ini?

Jawab :

Misalkan A : Kejadian Amir meninggal tahun ini

B : Kejadian Bakri meninggal tahun ini

Maka, diketahui $\mathrm{P}(\mathrm{A})=0,7$ dan $\mathrm{P}(\mathrm{B})=0,9$

a) Peluang Keduanya masih hidup $=\mathrm{P}\left(\mathrm{A}^{\mathrm{C}} \cap \mathrm{B}^{\mathrm{C}}\right)$

$$
\begin{aligned}
& =P\left(A^{C}\right) \times P\left(B^{C}\right) \\
& =[1-P(A)][1-P(B)]=0,3 \times 0,1 \\
& =0,003
\end{aligned}
$$

b) Peluang tepat satu sudah meninggal $=\mathrm{P}\left(\left(\mathrm{A} \cap \mathrm{B}^{\mathrm{C}}\right) \cup\left(\mathrm{A}^{\mathrm{C}} \cap \mathrm{B}\right)\right)$

$$
\begin{aligned}
& =\mathrm{P}\left(\mathrm{A} \cap \mathrm{B}^{\mathrm{C}}\right)+\mathrm{P}\left(\mathrm{A}^{\mathrm{C}} \cap \mathrm{B}\right) \\
& =\mathrm{P}(\mathrm{A}) \mathrm{P}\left(\mathrm{B}^{\mathrm{C}}\right)+\mathrm{P}\left(\mathrm{A}^{\mathrm{C}}\right) \mathrm{P}(\mathrm{B})
\end{aligned}
$$




\section{\begin{tabular}{l|l} 
Pengantar Matematika Aktuaria & 2018
\end{tabular}}

$$
\begin{aligned}
& =0,7(0,1)+0,9(0,03) \\
& =0,07+0,27=0,34
\end{aligned}
$$

2) Peluang seorang pria berusia 20 dan berusia 40 masih hidup dua-duanya 20 tahun lagi adalah 0,6. Dari 50.000 pria yang hidup pada usia 20, 3000 akan meninggal sebelum mencapai usia 25. Tentukan peluang seorang pria berusia 25 tahun untuk hidup 35 tahun lagi.

Jawab :

Misalkan

$A=$ kejadian seorang berusia 20 hidup 20 tahun lagi (s/d usia 40)

$B=$ kejadian seorang berusia 40 hidup 20 tahun lagi (s/d usia 60)

$C=$ kejadian seorang berusia 20 hidup s/d usia 60

D = kejadian seorang berusia 20 hidup s/d usia 25

$\mathrm{E}=$ kejadian seorang berusia 25 hidup s/d usia 60

Maka, diketahui

$$
\begin{aligned}
& \mathrm{P}(\mathrm{A} \cap \mathrm{B})=0,6 \\
& \begin{aligned}
\mathrm{P}(\mathrm{C}) & =0,6 \\
\mathrm{P}(\mathrm{D}) & =\frac{47.000}{50.000} \\
& =0,94
\end{aligned} \\
& C=\mathrm{D} \cap \mathrm{E}
\end{aligned}
$$

karena saling bebas,

$P(C)=P(D) . P(E)$ 


\section{\begin{tabular}{l|l} 
Pengantar Matematika Aktuaria & 2018
\end{tabular}}

$$
P(E)=\frac{P(C)}{P(D)}=\frac{0,6}{0,94}=\frac{30}{47}
$$

3) Peluang seseorang berusia 20 tahun hidup 20 tahun lagi adalah 0,9. sementara peluang seseorang berusia 40 tahun hidup 10 tahun lagi adalah 0,8 , berapa peluang seseorang berusia 20
a) Hidup 30 tahun lagi?
b) Meninggal sebelum usia 50?
c) Meninggal antara usia 40 dan 50 ?

Jawab :

Misalkan

$$
\begin{aligned}
& A=\text { kejadian seseorang berusia } 20 \text { tahun hidup sampai usia } 40 \\
& B=\text { kejadian seseorang berusia } 40 \text { tahun hidup sampai usia } 50
\end{aligned}
$$

Diketahui:

$$
\begin{aligned}
& P(A)=0,9 \\
& P(B)=0,8
\end{aligned}
$$

Ditanya:

$$
\mathrm{P}(\mathrm{A} \cap \mathrm{B}), \mathrm{P}\left((\mathrm{A} \cap \mathrm{B})^{\mathrm{C}}\right), \mathrm{P}\left(\mathrm{A} \cap \mathrm{B}^{\mathrm{C}}\right)
$$

Jawab:

a) $\mathrm{P}(\mathrm{A} \cap \mathrm{B})=\mathrm{P}(\mathrm{A}) \times \mathrm{P}(\mathrm{B})$

$$
\begin{aligned}
& =0,9 \times 0,8 \\
& =0,72
\end{aligned}
$$

b) $\mathrm{P}\left((\mathrm{A} \cap \mathrm{B})^{\mathrm{C}}\right)=1-\mathrm{P}(\mathrm{A} \cap \mathrm{B})$

$$
=1-0,72
$$




\section{\begin{tabular}{l|l} 
Pengantar Matematika Aktuaria & 2018
\end{tabular}}

$$
\begin{aligned}
& =0,28 \\
\text { c) } \mathrm{P}\left(\mathrm{A} \cap \mathrm{B}^{\mathrm{C}}\right) & =\mathrm{P}(\mathrm{C}) \times \mathrm{P}\left(\mathrm{B}^{\mathrm{C}}\right) \\
& =0,9(1-0,8) \\
& =0,18
\end{aligned}
$$

4) Peluang seseorang berusia $x$ akan meninggal dalam 1 tahun adalah 1/10. A, B, C, D berusia $\mathrm{x}$. Tentukan peluang bahwa dari empat orang tersebut $\mathrm{A}$ meninggal pertama dalam 1 tahun tersebut.

Jawab :

$\mathrm{P}($ A meninggal pertama dalam 1 tahun $)$

$$
\begin{aligned}
& =\mathrm{P}(\text { A meninggal dalam } 1 \text { tahun }) \cdot \mathrm{P}(\text { A yang pertama meninggal }) \\
& =0,1 \cdot \frac{6}{24} \\
& =0,025
\end{aligned}
$$

\section{B. Tabel Mortalitas}

Tabel mortalitas (mortality table/life table) pada umumnya adalah daftar kehidupan dan kematian dari sekelompok orang. Kadang-kadang, life table juga dibuat untuk produk seperti barang elektronik, mesin, dll.

Manfaatnya

1. Terutama untuk melihat kemungkinan kematian seseorang dalam jangka waktu tertentu.

2. Menaksir distribusi survival untuk data yang kontinu 


\section{\begin{tabular}{l|l} 
Pengantar Matematika Aktuaria & 2018
\end{tabular}}

Tabel mortalitas ada bermacam-macam karena disesuaikan dengan kebutuhan-kebutuhan dan dipengaruhi oleh faktor geografis, jenis kelamin dan lain-lain. Walaupun demikian, setiap tabel mortalitas mestilah memuat:

1. Usia (dilambangkan dengan $\mathrm{x}$ ) yang dimulai dari usia 0 sampai usia tertinggi dimana diperkirakan masih ada orang yang hidup (dilambangkan dengan $\omega$ ).

2. Jumlah orang yang masih hidup pada usia $\mathrm{x}$ (dilambangkan dengan $\mathrm{l}_{\mathrm{x}}$ ). Jika dikaitkan dengan $\omega$, maka $l_{\omega}>0$ dan $l_{\omega+1}=l_{\omega+2}=. .=0$.

3. Jumlah orang yang meninggal dalam setahun setelah usia $\mathrm{x}$ (dilambangkan dengan $d_{x}$ ).

4. Peluang seseorang berusia $\mathrm{x}$ untuk hidup 1 tahun lagi (dilambangkan dengan $1 \mathrm{p}_{\mathrm{x}}$ atau $\mathrm{p}_{\mathrm{x}}$ saja).

5. Peluang seseorang berusia $\mathrm{x}$ meninggal dalam 1 tahun (dilambangkan dengan ${ }_{1} \mathrm{q}_{\mathrm{x}}$ atau $\mathrm{q}_{\mathrm{x}}$ saja).

6. Harapan hidup seseorang berusia $\mathrm{x}$ (dilambangkan dengan $\mathrm{e}_{\mathrm{x}}$ )

Pembentukan tabel bisa dilakukan dengan berbagai cara, diantaranya:

1. Cara konvensional, dimana pengamatan dilakukan melalu suatu jangka waktu yang panjang terhadap sekelompok sampel orang yang kemudian didata umur kematiannya.

2. Metode fraksi umur terakhir 


\section{Pengantar Matematika Aktuaria 2018}

Pada buku ini akan diberikan gambaran tentang pembentukan secara konvensional.

1. Dari sensus/survei/pengamatan diperoleh $l_{\mathrm{x}}$ dan $\mathrm{d}_{\mathrm{x}}$.

Semua bayi yang lahir pada tahun awal pengamatan didata dan jumlahnya ditulis sebagi $l_{0}$. Dalam satu tahun, bayi yang meninggal didata dan ditulis sebagai $\mathrm{d}_{0}$. Sisanya $\left(\mathrm{l}_{0}-\mathrm{d}_{0}\right)$ adalah bayi yang masih hidup pada usia 1 atau ditulis $l_{1}$. dst.

Jadi, $\mathrm{l}_{\mathrm{i}+1}=\mathrm{l}_{\mathrm{i}}-\mathrm{d}_{\mathrm{i}}$

2. $\mathrm{p}_{\mathrm{x}}, \mathrm{q}_{\mathrm{x}}$, dan $\mathrm{e}_{\mathrm{x}}$ diperoleh dengan perhitungan:

$$
\begin{aligned}
& \mathrm{p}_{\mathrm{x}}=\frac{1_{\mathrm{x}+1}}{\mathrm{l}_{\mathrm{x}}} \\
& \mathrm{p}_{\mathrm{x}}=1-\frac{\mathrm{d}_{\mathrm{x}}}{\mathrm{l}_{\mathrm{x}}} \\
& \mathrm{q}_{\mathrm{x}}=1-\mathrm{p}_{\mathrm{x}}=\frac{\mathrm{d}_{\mathrm{x}}}{1_{\mathrm{x}}}
\end{aligned}
$$

Harapan hidup seseorang berusia $\mathbf{x}\left(e_{\mathrm{x}}\right)$ didefinisikan sebagai rata-rata tahun yang bisa dilewati dalam keadaan hidup oleh seseorang berusia $\mathrm{x}$.

Oleh karena itu, formulanya

$$
\begin{aligned}
\mathrm{e}_{\mathrm{x}}= & \frac{\text { jumlah tahun yang masih bisa dilewati orang-orang berusia } \mathrm{x}}{\text { jumlah orang yang berusia } \mathrm{x}} \\
& =\frac{\mathrm{l}_{\mathrm{x}+1}+\mathrm{l}_{\mathrm{x}+2}+\ldots+\mathrm{l}_{\omega}}{\mathrm{l}_{\mathrm{x}}}
\end{aligned}
$$




\section{\begin{tabular}{l|l} 
Pengantar Matematika Aktuaria & 2018
\end{tabular}}

Dalam penggunaan tabel mortalitas selanjutnya, juga kita kenal tiga buah notasi lain. Berikut adalah definisi dan formulasinya.

a) ${ }_{n} \mathbf{p}_{\mathbf{x}}$ didefinisikan sebagai peluang seseorang berusia $\mathrm{x}$ hidup $\mathrm{n}$ tahun lagi dan diformulasikan

$$
\begin{aligned}
& { }_{n} p_{x}=\frac{\text { jumlah orang yang masih hidup pada usia } \mathrm{x}+\mathrm{n}}{\text { jumlah orang yang masih hidup pada usia } \mathrm{x}} \\
& { }_{\mathrm{n}} \mathrm{p}_{\mathrm{x}}=\frac{\mathrm{l}_{\mathrm{x}+\mathrm{n}}}{\mathrm{l}_{\mathrm{x}}}
\end{aligned}
$$

b) $\mathbf{n q}_{\mathbf{x}}$ didefinisikan sebagai peluang seseorang berusia $\mathrm{x}$ akan meninggal dalam $\mathrm{n}$ tahun dan diformulasikan

$$
\begin{aligned}
& n q_{x}=1-{ }_{n} p_{x}=1-\frac{l_{x+n}}{l_{x}} \\
& n q_{x}=\frac{l_{x}-l_{x+n}}{l_{x}}
\end{aligned}
$$

c) $\mathbf{m} \mid \mathbf{n} \mathbf{q}_{\mathbf{x}}$ didefinisikan sebagai peluang seseorang berusia $\mathrm{x}$ hidup $\mathrm{m}$ tahun lagi, tapi meninggal pada $\mathrm{n}$ tahun berikutnya dan diformulasikan

$$
\begin{aligned}
m \mid n q_{x} & ={ }_{m} p_{x} \cdot{ }_{n} q_{x+m}=\frac{l_{x+m}}{l_{x}} \cdot \frac{l_{x+m}-l_{x+m+n}}{l_{x+m}} \\
m \mid n & q_{x}=\frac{l_{x+m}-l_{x+m+n}}{l_{x}}
\end{aligned}
$$




\section{\begin{tabular}{l|l} 
Pengantar Matematika Aktuaria & 2018
\end{tabular}}

\section{Contoh}

1. Dengan menggunakan tabel mortalitas, hitunglah peluang seorang perempuan berusia 21 untuk:
a. Hidup sampai usia 65
b. Hidup antara usia 40-50

Jawab :

a. $\mathrm{x}=21$

$\mathrm{n}=44$

${ }_{n} p_{x}=\frac{1_{x+n}}{1_{x}}$

$=\frac{1_{65}}{1_{21}}=\frac{861.494}{990.468}=0,869785$

b. $\mathrm{n}|\mathrm{m}=19| 10$

$x=21$

$\mathrm{n} \mid \mathrm{m} \mathrm{q}_{\mathrm{x}}=\frac{1_{40}-1_{50}}{1_{21}}$

$=\frac{979.747-961.030}{990.468}$

$=0,018897$

Peluang hidup antara usia 40-50 adalah $1-0,018897=0,981103$.

2) Buktikan :

a. $\quad n \mid m q_{x}={ }_{m} p_{x} \cdot{ }_{n} q_{x+n}$

b. $3 p_{x}=p_{x} \cdot p_{x+1} \cdot p_{x+2}$

c. jika $l_{x}=k(185-2 x)$, tentukan $P_{85}$ 


\section{Pengantar Matematika Aktuaria 2018}

Jawab

a. ${ }_{m} p_{x} \cdot{ }_{n} q_{x+n}=\frac{1_{x+m}}{1_{x}} \cdot \frac{1_{x+m+n}-1_{x+m+n}}{1_{x+m}}$

$$
\begin{aligned}
& =\frac{1_{x+m}-1_{x+m+n}}{1_{x}} \\
& =n / m q_{x}
\end{aligned}
$$

b. $\quad p_{x} \cdot p_{x+1} \cdot p_{x+2}=\frac{1_{x+1}}{1_{x}} \cdot \frac{1_{x+2}}{1_{x+1}} \cdot \frac{1_{x+3}}{1_{x+2}}$

$$
\begin{aligned}
& =\frac{1_{x+3}}{1_{x}} \\
& =3 p_{x}
\end{aligned}
$$

c. $\mathrm{p}_{\mathrm{x}}=\frac{1_{\mathrm{x}+1}}{1_{\mathrm{x}}}$

$$
\mathrm{p}_{85}=\frac{\mathrm{l}_{86}}{1_{85}}=\frac{\mathrm{k}(185-2 \times 86)}{\mathrm{k}(185-2 \times 85)}=\frac{13}{15}
$$

3) Buktikan $e_{x}=p_{x}\left(1+e_{x+1}\right)$

Jawab :

$$
\begin{aligned}
e_{x}\left(1+e_{x+1}\right) & =\frac{l_{x+1}}{l_{x}}\left[1+\left(\frac{l_{x+2}+l_{x+3}+\ldots+l_{\omega}}{l_{x+1}}\right)\right] \\
& =\frac{l_{x+1}}{l_{x}}+\frac{l_{x+2}}{l_{x}}+\frac{l_{x+3}}{l_{x}}+. .+\frac{l_{\omega}}{l_{x}}=e_{x} .
\end{aligned}
$$

4) Lelaki A dan wanita B menikah ketika masing-masing berusia 25 dan 21 tahun. Ketika perayaan "Kawin Perak" mereka punya anak laki-laki berusia 24 dan 21 tahun. Berapa peluang semua anggota keluarga masih hidup pada perayaan "Kawin Emas" A dan B? (Keterangan: Perayaan 


\section{Pengantar Matematika Aktuaria 2018}

"Kawin Perak" dilakukan ketika perkawinan tepat 25 tahun, sementara

"Kawin Emas" dirayakan ketika perkawinan tepat 50 tahun)

Jawab :

$$
\begin{aligned}
\mathrm{P} & ={ }_{25} \mathrm{p}_{46 \cdot 25} \mathrm{p}_{50 \cdot 25} \mathrm{p}_{24 \cdot 25} \mathrm{p}_{21} \\
& =\frac{1_{50+25}}{1_{50}} \cdot \frac{1_{46+25}}{1_{46}} \cdot \frac{1_{24+25}}{1_{24}} \cdot \frac{1_{21+25}}{1_{21}} \\
& =0.45314986
\end{aligned}
$$

\section{Latihan}

1. Buktikan
a. $\mathrm{q}_{\mathrm{x}}+\mathrm{p}_{\mathrm{x}} \mathrm{q}_{\mathrm{x}+1}+{ }_{2} \mathrm{p}_{\mathrm{x}} \mathrm{q}_{\mathrm{x}+2}+. .=1$
b. ${ }_{n} p_{x}=\frac{{ }_{n} p_{x}-{ }_{n+1} p_{x}}{q_{x+n}}$

2. Suatu survei menunjukkan bahwa dari 100 orang pria yang dilahirkan pada waktu yang sama, satu orang akan meninggal setiap tahun sampai tidak ada lagi yang tersisa. Jika diketahui lima tahun yang lalu hidup tiga orang berusia 20,30 , dan 60 , tentukan peluang bahwa ketiganya masih hidup saat ini.

3. Peluang seorang berusia 18 akan hidup 10 tahun lagi adalah 0,95 , dan akan hidup 30 tahun lagi adalah 0,75. Tentukan peluang seorang berusia 28 meninggal sebelum mencapai usia 48.

4. Peluang bahwa tepat satu dari tiga orang berusia 20,35 , dan 50 akan hidup 15 tahun berikutnya adalah 0,092. Peluang bahwa ketiganya akan 


\section{\begin{tabular}{l|l} 
Pengantar Matematika Aktuaria & 2018
\end{tabular}}

meninggal dalam 15 tahun berikutnya adalah 0,006. Peluang orang berusia 20 akan meninggal sebelum usia 35 adalah 0,1. Tentukan peluang orang berusia 20 akan hidup sampai usia 65.

5. Sebuah keluarga mempunyai anak laki-laki berusia 1 dan 11 tahun. Dengan tabel mortalitas, tentukan peluang tepat satu diantaranya meninggal sebelum usia 50.

6. Dengan data $l_{70}=801, l_{71}=486, l_{72}=260$, dan $l_{73}=39$, sementara $\omega=73$, buatlah tabel mortalitas untuk data tersebut.

7. Dengan menggunakan tabel mortalitas, tentukan peluang seorang wanita berusia 65 akan hidup setidaknya 15 tahun lagi.

8. Seorang pria berusia 35 tahun menikah dengan seorang wanita berusia 22 tahun. Tiga tahun kemudian mereka memperoleh anak perempuan kembar. Dengan menggunakan tabel mortalitas, tentukanlah peluang salah satu anak sudah meninggal ketika mereka merayakan kawin peraknya (25 tahun perkawinan).

9. Jika $\mathrm{l}_{\mathrm{x}}=200(100-\mathrm{x})$, tentukanlah ${ }_{2} \mid \mathrm{q}_{\mathrm{x}}$.

10. Lengkapi tabel berikut

\begin{tabular}{|c|c|c|c|}
\hline $\mathrm{x}$ & $\begin{array}{c}\text { Peluang } \\
\text { meninggal }\end{array}$ & $\mathrm{l}_{\mathrm{x}}$ & $\mathrm{d}_{\mathrm{x}}$ \\
\hline 95 & $1 / 3$ & 1500 & \\
\hline 96 & $2 / 5$ & & \\
\hline 97 & $1 / 2$ & & \\
\hline 98 & $2 / 3$ & & \\
\hline 99 & 1 & & \\
\hline 100 & & & \\
\hline
\end{tabular}




\section{\begin{tabular}{l|l} 
Pengantar Matematika Aktuaria & 2018
\end{tabular}}

11. Lengkapi tabel berikut (hitung sampai 4 desimal)

\begin{tabular}{|c|c|c|c|c|c|}
\hline $\mathrm{x}$ & $\mathrm{l}_{\mathrm{x}}$ & $\mathrm{d}_{\mathrm{x}}$ & $\mathrm{p}_{\mathrm{x}}$ & $\mathrm{q}_{\mathrm{x}}$ & $\mathrm{e}_{\mathrm{x}}$ \\
\hline 95 & 1000 & & & & \\
\hline 96 & 700 & & & & \\
\hline 97 & 400 & & & & \\
\hline 98 & 100 & & & & \\
\hline 99 & 10 & & & & \\
\hline 100 & & & & & \\
\hline
\end{tabular}




\section{Pengantar Matematika Aktuaria 2018}

\section{BAB V}

\section{ANUITAS HIDUP}

Anuitas hidup adalah anuitas dengan syarat yang bersangkutan (pembayar/penerima) masih hidup. Contohnya antara lain:

1. premi asuransi atau kredit berasuransi dimana kewajiban (berupa cicilan) hanya dibayar kalau klien/pengutang masih hidup

2. pembayaran gaji atau pensiun.

Menurut periode waktunya, anuitas hidup dapat dikelompokkan menjadi tiga kelompok utama, yaitu:

1. Anuitas hidup berjangka $n$ tahun

Pada anuitas jenis ini, kewajiban pembayaran dilakukan dalam jangka waktu $\mathrm{n}$ tahun selama yang bersangkutan masih hidup.

2. Anuitas seumur hidup

Kewajiban pembayaran akan dilakukan seumur hidup (sampai yang bersangkutan meninggal).

3. Anuitas hidup yang ditunda $m$ tahun

Kewajiban pembayaran pertama anuitas ini dimulai $m$ tahun dari sekarang. Jenisnya bisa anuitas berjangka $\mathrm{n}$ tahun atau seumur hidup. 


\section{\begin{tabular}{l|l} 
Pengantar Matematika Aktuaria & 2018
\end{tabular}}

Kita tahu bahwa perbedaan antara anuitas hidup dengan anuitas pasti adalah tidak pastinya semua pembayaran terjadi karena dipengaruhi hidup/tidaknya si penerima/pembayar. Dengan demikian, dalam perhitungannya, formula anuitas pasti dengan anuitas hidup hanya berbeda dalam hal peluang anuitas tersebut dilakukan, yaitu 1 untuk anuitas pasti dan $\mathrm{p}_{\mathrm{x}}$ untuk anuitas hidup. Berikut akan kita turunkan formulanya.

\section{A. Anuitas hidup berjangka $n$ tahun.}

1. Anuitas awal

Misalkan nilai sekarang dari semua anuitas sebesar 1 rupiah sebanyak $\mathrm{n}$ kali, yang dilakukan seseorang berusia $\mathrm{x}$ di awal periode (tahun) selama ia masih hidup dilambangkan dengan $\mathrm{a}_{\mathrm{x}: \mathrm{n}}$. . Perhatikan tabel nilai sekarang dari anuitas yang sudah dilengkapi dengan peluang terjadinya anuitas.

Tabel 16. Tabel Nilai Sekarang dari Anuitas Hidup Berjangka Awal

\begin{tabular}{|c|c|c||c|}
\hline $\begin{array}{c}\text { Periode } \\
\text { Pembayaran }\end{array}$ & $\begin{array}{c}\text { Besar } \\
\text { pembayaran }\end{array}$ & Nilai Sekarang & $\begin{array}{c}\text { Peluang terjadinya } \\
\text { pembayaran }\end{array}$ \\
\hline I & 1 & $1=\mathrm{v}^{0}$ & $1={ }_{0} \mathrm{p}_{\mathrm{x}}$ \\
\hline II & 1 & $\mathrm{v}^{1}$ & $1 \mathrm{p}_{\mathrm{x}}$ \\
\hline III & 1 & $\mathrm{v}^{2}$ & $2 \mathrm{p}_{\mathrm{x}}$ \\
\hline$\ldots$ & $\ldots$ & $\ldots$ & $\ldots$ \\
\hline $\mathrm{ke}-\mathrm{n}$ & 1 & $\mathrm{v}^{\mathrm{n}-1}$ & $\mathrm{n}-1 \mathrm{p}_{\mathrm{x}}$ \\
\hline
\end{tabular}




\section{\begin{tabular}{l|l} 
Pengantar Matematika Aktuaria & 2018
\end{tabular}}

Jadi, nilai sekarang dari semua pembayaran berikut peluangnya, adalah

$$
\begin{aligned}
\mathrm{a}_{\mathrm{x}: \mathrm{n}} & =\mathrm{v}^{0}{ }_{0} \mathrm{p}_{\mathrm{x}}+\mathrm{v}^{1}{ }_{1} \mathrm{p}_{\mathrm{x}}+\mathrm{v}^{2}{ }_{2} \mathrm{p}_{\mathrm{x}}+\ldots+\mathrm{v}^{\mathrm{n}-1}{ }_{\mathrm{n}-1} \mathrm{p}_{\mathrm{x}} \\
& =\sum_{\mathrm{k}=0}^{\mathrm{n}-1} \mathrm{v}^{\mathrm{k}}{ }_{\mathrm{k}} \mathrm{p}_{\mathrm{x}} \\
& =\sum_{\mathrm{k}=0}^{\mathrm{n}-1} \mathrm{v}^{\mathrm{k}} \frac{1_{\mathrm{x}+\mathrm{k}}}{1_{\mathrm{x}}} \\
& =\sum_{\mathrm{k}=0}^{\mathrm{n}-1} \frac{\mathrm{v}^{\mathrm{x}+\mathrm{k}} 1_{\mathrm{x}+\mathrm{k}}}{\mathrm{v}^{\mathrm{x}} 1_{\mathrm{x}}}
\end{aligned}
$$

Untuk kemudahan perhitungan, maka pada bagian ini akan diperkenalkan enam notasi komutasi yang akan berguna untuk seterusnya.

$$
\begin{aligned}
& D_{x}=v^{x} 1_{x} \\
& N_{x}=D_{x}+D_{x+1}+D_{x+2}+. .+D_{\omega} \\
& S_{x}=N_{x}+N_{x+1}+N_{x+2}+. .+N_{\omega} \\
& C_{x}=v^{x+1} d_{x} \\
& M_{x}=C_{x}+C_{x+1}+C_{x+2}+. .+C_{\omega} \\
& R_{x}=M_{x}+M_{x+1}+M_{x+2}+. .+M_{\omega}
\end{aligned}
$$

Maka, dengan bantuan notasi komutasi di atas, formula untuk anuitas hidup berjangka n di awal periode tersebut bisa kita tulis sebagai

$$
\begin{aligned}
a_{x: n}= & \sum_{k=0}^{n-1} \frac{v^{x+k} 1_{x+k}}{v^{x} 1_{x}} \\
& =\sum_{k=0}^{n-1} \frac{D_{x+k}}{D_{x}} \\
& =\frac{1}{D_{x}}\left(D_{x}+D_{x+1}+D_{x+2}+. .+D_{x+n-1}\right)
\end{aligned}
$$




\section{\begin{tabular}{l|l} 
Pengantar Matematika Aktuaria & 2018
\end{tabular}}

Formula di atas masih belum cukup praktis. Selanjutnya, perhatikan bahwa

$$
\mathrm{D}_{\mathrm{x}}=\mathrm{N}_{\mathrm{x}}-\mathrm{N}_{\mathrm{x}+1}
$$

Maka, kita bisa sederhanakan lagi formula sebelumnya menjadi

$$
\begin{aligned}
a_{x: n} & =\frac{1}{D_{x}}\left(D_{x}+D_{x+1}+D_{x+2}+. .+D_{x+n-1}\right) \\
& =\frac{1}{D_{x}}\left[\left(N_{x}-N_{x+1}\right)+\left(N_{x+1}-N_{x+2}\right)+. .+\left(N_{x-n+1}-N_{x+n}\right)\right] \\
& =\frac{N_{x}-N_{x+n}}{D_{x}}
\end{aligned}
$$

Jadi, formula untuk nilai sekarang anuitas hidup berjangka $\mathrm{n}$ tahun dengan pembayaran anuitas 1 rupiah di awal adalah

$$
a_{x: n}=\frac{N_{x}-N_{x+n}}{D_{x}}
$$

\section{Contoh}

1. Seorang pria berusia 40 tahun ingin membuat pembayaran setiap awal tahun selama 25 tahun untuk pembayaran pinjaman sebesar 80 juta rupiah. Pada $\mathrm{i}=5 \%$, tentukan:

a. Nilai pembayaran tahunan yang ia lakukan

b. Nilai pembayaran tahunan juga, tetapi jika pinjaman dianggap lunas kalau ia meninggal.

Jawab :

a. Misalkan pembayaran tahunan $=\mathrm{P}$

Dkt: $\mathrm{n}=25$ 


\section{\begin{tabular}{l|l} 
Pengantar Matematika Aktuaria & 2018
\end{tabular}}

Nilai sekarang pinjaman = Nilai sekarang anuitas pembayaran

$$
\begin{aligned}
& 80.000 .000=\mathrm{P} \mathrm{a}_{25} \\
& 80.000 .000=\mathrm{P} \frac{1-\mathrm{v}^{25}}{1-\mathrm{v}}=\mathrm{P} \frac{1-\left(\frac{1}{1+0,05}\right)^{25}}{1-\frac{1}{1,05}} \\
& \mathrm{P}=\frac{80.000 .000}{14,1} \\
& \approx \mathrm{Rp} .5 .405 .592,-
\end{aligned}
$$

b. Nilai sekarang pinjaman = Nilai sekarang anuitas

$$
\begin{aligned}
80.000 .000 & =\mathrm{Pa}_{40: \overline{25}} \\
& =\mathrm{P} \frac{\mathrm{N}_{40}-\mathrm{N}_{65}}{\mathrm{D}_{40}} \\
\mathrm{P} & \approx \text { Rp.5.632.403,- }
\end{aligned}
$$

2. Anuitas akhir.

Misalkan nilai sekarang dari semua anuitas sebesar 1 rupiah sebanyak n kali, yang dilakukan seseorang berusia x di akhir periode selama ia masih hidup dilambangkan dengan $a_{x: n}$, maka dengan cara yang sama (buktikan!), kita peroleh

$$
a_{x: n}=\sum_{i=1}^{n}{ }_{i} p_{x} v^{i} \text { atau } a_{x: n \mid}=\frac{N_{x+1}-N_{x+n+1}}{D_{x}}
$$




\section{Pengantar Matematika Aktuaria 2018}

\section{B. Anuitas seumur hidup}

1. Anuitas awal

$$
\mathrm{a}_{\mathrm{x}}=\sum_{\mathrm{i}=0}^{\omega-\mathrm{x}}{ }_{\mathrm{i}} \mathrm{p}_{\mathrm{x}} \mathrm{v}^{\mathrm{i}} \quad \text { atau } \quad \mathrm{a}_{\mathrm{x}}=\frac{\mathrm{N}_{\mathrm{x}}}{\mathrm{D}_{\mathrm{x}}}
$$

2. Anuitas akhir

$$
\mathrm{a}_{\mathrm{x}}=\sum_{\mathrm{i}=1}^{\omega-\mathrm{x}}{ }_{\mathrm{i}} \mathrm{p}_{\mathrm{x}} \mathrm{v}^{\mathrm{i}} \quad \text { atau } \quad \mathrm{a}_{\mathrm{x}}=\frac{\mathrm{N}_{\mathrm{x}+1}}{\mathrm{D}_{\mathrm{x}}}
$$

Contoh

1. Seorang wanita berusia 20 tahun mesti membayar tiap awal tahun cicilan hutang sebesar Rp.5.000.000,- selama ia masih hidup. Berapa besar utangnya pada suku bunga $6 \%$ ?

Jawab.

Dkt: $\quad \mathrm{x}=20$

$$
\mathrm{i}=0,06
$$

Persamaan Nilai :

Nilai sekarang utang = Nilai sekarang anuitas

$$
\begin{aligned}
& =5.000 .000 \mathrm{a}_{20} \\
& =5.000 .000 \frac{\mathrm{N}_{20}}{\mathrm{D}_{20}} \\
& \approx \operatorname{Rp} .84 .468 .709,-
\end{aligned}
$$




\section{\begin{tabular}{l|l} 
Pengantar Matematika Aktuaria & 2018
\end{tabular}}

2. Seorang pria berusia 30 tahun berutang 50 juta rupiah. Jika pembayarannya dilakukan tiap akhir tahun selama ia masih hidup, tentukan berapa nilai tiap pembayaran tersebut pada suku bunga $5 \%$.

Jawab.

Dkt: $\quad x=30$

Misalkan A = Besar pembayaran tiap tahun

Persamaan Nilai:

Nilai utang sekarang = Nilai anuitas sekarang

$$
\begin{gathered}
50.000 .000=A \frac{N_{30+1}}{D_{30}} \\
50.000 .000=A \frac{N_{31}}{D_{30}} \\
A \approx \text { Rp.2.897.226,- }
\end{gathered}
$$

\section{Anuitas hidup yang ditunda}

Pelaksanaan anuitas ditunda $\mathrm{m}$ tahun. Akibatnya, kita peroleh formulaformula berikut.

Anuitas hidup yang ditunda m tahun

1. awal

$$
{ }_{\mathrm{m}} \mid \mathrm{a}_{\mathrm{x}}=\sum_{\mathrm{i}=\mathrm{m}}^{\omega}{ }_{\mathrm{i}} \mathrm{p}_{\mathrm{x}} \mathrm{v}^{\mathrm{i}} \text { atau } \mathrm{m}_{\mathrm{x}} \mid \mathrm{a}_{\mathrm{x}}=\frac{\mathrm{N}_{\mathrm{x}+\mathrm{m}}}{\mathrm{D}_{\mathrm{x}}}
$$




\section{\begin{tabular}{l|l} 
Pengantar Matematika Aktuaria & 2018
\end{tabular}}

2. akhir

$$
{ }_{\mathrm{m}} \mid \mathrm{a}_{\mathrm{x}}=\sum_{\mathrm{i}=\mathrm{m}+1}^{\omega}{ }_{\mathrm{i}} \mathrm{p}_{\mathrm{x}} \mathrm{v}^{\mathrm{i}} \text { atau } \mid \mathrm{a}_{\mathrm{x}}=\frac{\mathrm{N}_{\mathrm{x}+\mathrm{m}+1}}{\mathrm{D}_{\mathrm{x}}}
$$

Anuitas hidup berjangka $\mathrm{n}$ tahun yang ditunda $\mathrm{m}$ tahun

1. awal

$$
m \mid a_{x: n}=\sum_{i=m}^{m+n}{ }_{i} p_{x} v^{i} \quad \text { atau } \mid a_{x: n}=\frac{N_{x+m}-N_{x+m+n}}{D_{x}}
$$

2. akhir

$$
\mathrm{m} \mid \mathrm{a}_{\mathrm{x}: \mathrm{n}}=\sum_{\mathrm{i}=\mathrm{m}+1}^{\mathrm{m}+\mathrm{n}+1} \mathrm{i}_{\mathrm{x}} \mathrm{v}^{\mathrm{i}} \text { atau } \mathrm{a}_{\mathrm{x}: \mathrm{n}}=\frac{\mathrm{N}_{\mathrm{x}+\mathrm{m}+1}-\mathrm{N}_{\mathrm{x}+\mathrm{m}+\mathrm{n}+1}}{\mathrm{D}_{\mathrm{x}}}
$$

Contoh soal berkaitan anuitas hidup

1. Tunjukkan: $\mathrm{D}_{\mathrm{x}+1}=\mathrm{vp}_{\mathrm{x}} \mathrm{D}_{\mathrm{x}}$

Jawab :

$$
\mathrm{vp}_{\mathrm{x}} \mathrm{D}_{\mathrm{x}}=\mathrm{v} \frac{1_{\mathrm{x}+1}}{1_{\mathrm{x}}} \cdot 1_{\mathrm{x}} \mathrm{v}^{\mathrm{x}}=1_{\mathrm{x}+1} \mathrm{v}^{\mathrm{x}+1}=\mathrm{D}_{\mathrm{x}+1}
$$

2. Tunjukkan secara matematis bahwa $\mathrm{a}_{\mathrm{x}: \mathrm{n}}+_{\mathrm{n}} \mid \mathrm{a}_{\mathrm{x}}=\mathrm{a}_{\mathrm{x}}$. Selanjutnya, jelaskan dengan kata-kata!

Jawab :

$$
a_{x: n}+{ }_{n} \mid a_{x}=\frac{N_{x}-N_{x+n}}{D_{x}}+\frac{N_{x+n}}{D_{x}}=\frac{N_{x}-N_{x+n}+N_{x+n}}{D_{x}}=\frac{N_{x}}{D_{x}}=a_{x}
$$




\section{\begin{tabular}{l|l} 
Pengantar Matematika Aktuaria & 2018
\end{tabular}}

Nilai sekarang dari anuitas (awal) hidup berjangka $n$ tahun dengan anuitas

(awal) seumur hidup yang ditunda $n$ tahun sama dengan nilai sekarang anuitas (awal) seumur hidup.

\section{Endowmen}

Endowmen adalah pembayaran yang dilakukan kepada seseorang jika masih hidup pada akhir waktu tertentu. Misalkan: Seseorang berusia 25 tahun akan menerima Rp.100.000.000,- jika masih hidup pada usia 65 tahun.

Nilai sekarang dari Endowmen sebesar 1 rupiah untuk seseorang berusia $\mathrm{x}$ jika masih hidup $\mathrm{k}$ tahun lagi adalah ${ }_{\mathrm{k}} \mathrm{E}_{\mathrm{x}}$. Dengan demikian, akan memenuhi

$$
{ }_{k} E_{x}=v^{k}{ }_{k} p_{x}=v^{k} \frac{1_{x+k}}{1_{x}}=\frac{v^{x+k} 1_{x+k}}{v^{x} 1_{x}}=\frac{D_{x+k}}{D_{x}}
$$

Contoh

1. Seorang wanita berusia 20 tahun dijanjikan akan menerima 1 milyar rupiah, jika masih hidup 50 tahun lagi. Berapa nilai sekarang dari janji tersebut pada suku bunga $5 \%$ ?

Jawab :

Dkt: $\quad x=20$

$$
n=50
$$

Persamaan Nilai:

Nilai sekarang $=1.000 .000 .000 \times{ }_{50} \mathrm{E}_{20}$ 


\section{Pengantar Matematika Aktuaria 2018}

$$
\begin{aligned}
& =1.000 .000 .000 \times \frac{D_{70}}{D_{20}} \\
& \approx \text { Rp.69.860.270,- }
\end{aligned}
$$

\section{E. Latihan}

1. Buktikan
a) $\quad D_{x}+2 D_{x+1}+3 D_{x+2}=S_{x}-S_{x+3}-3 N_{x+3}$
b) $a_{x+1}=\frac{(1+i) a_{x}}{p_{x}}$
c) $\quad a_{x}=v p_{x}+v^{2}{ }_{2} p_{x} a_{x+2}$
d) $\quad a_{x}=1+v p_{x} a_{x+1}$
e) $\quad a_{x}=v_{x}\left(1+a_{x+1}\right)$
f) $\quad(1+\mathrm{i}) \mathrm{a}_{\mathrm{x}}<\mathrm{e}_{\mathrm{x}}$
g) $\quad a_{x}<1 / i$
h) $\quad a_{x: n}<a_{n}$
i) $\quad{ }_{n} \mid a_{x: t}<v^{n} a_{t}$
j) $\quad 1+a_{x: n}=a_{x: n}+{ }_{n} E_{x}$
k) $\quad D_{x+1}=v_{x} D_{x}$
l) $\quad a_{x: m+n \mid}=a_{x: m \mid}+{ }_{m} E_{x} a_{x+m: n}$
m) $\quad a_{x}=a_{x: n}+{ }_{n} E_{x} a_{x+n}$
n) ${ }_{m} E_{x \quad t} E_{x+m}={ }_{m+t} E_{x}$ 


\section{\begin{tabular}{l|l} 
Pengantar Matematika Aktuaria & 2018
\end{tabular}}

o) $\quad a_{x: n}={ }_{1} E_{x} a_{x+1: n}$

p) $\quad{ }_{m} \mid a_{x: n}={ }_{m} E_{x} a_{x+m}-{ }_{m+n} E_{x} a_{x+m+n}$

q) $\quad a_{x: n}=a_{x}-v^{n}{ }_{n} p_{x} a_{x+n}$

2. Jika $\mathrm{a}_{20}=20,144, \mathrm{a}_{21}=20,013, \mathrm{a}_{22}=19,878, \mathrm{l}_{22}=91.192$, dan $\mathrm{i}=3,5 \%$, tentukanlah $\mathrm{d}_{20}$. Petunjuk: Gunakan identitas pada 1.e)

3. Seseorang pria berusia 27 ingin membuat pembayaran yang sama pada akhir setiap tahun selama 20 tahun untuk membayar utang sebesar Rp.90.000.000,- pada suku bunga 5\%. Jika sisa utang dianggap lunas pada waktu kematiannya, berapa cicilan tahunan yang mesti ia bayar?

4. B, seorang wanita yang sekarang berumur 10 tahun, akan menerima Rp.200.000.000,- untuk biaya kuliah S1 pada usia 18 dan Rp.200.000.000,- untuk biaya kuliah S2 pada usia 22. Tentukan nilai sekarangnya, pada suku bunga 6\%, jika uang itu

a. Pasti diterima.

b. Hanya diterima jika ia masih hidup.

5. Dengan asumsi i=7\%, lengkapi tabel berikut

\begin{tabular}{|c|c|c|c|c|c|c|}
\hline $\mathbf{x}$ & $\mathbf{l}_{\mathbf{x}}$ & $\mathbf{d}_{\mathbf{x}}$ & $\mathbf{q}_{\mathbf{x}}$ & $\mathbf{p}_{\mathbf{x}}$ & $\mathbf{a}_{\mathbf{x}}$ & $\mathbf{e}_{\mathbf{x}}$ \\
\hline 95 & 900 & 200 & & & & \\
\hline 96 & & & & & & \\
\hline 97 & 450 & & & 0,600 & & \\
\hline 98 & & & & & & \\
\hline 99 & 90 & & & & & \\
\hline 100 & 0 & & & & & \\
\hline
\end{tabular}




\section{\begin{tabular}{l|l} 
Pengantar Matematika Aktuaria & 2018
\end{tabular}}

6. Seorang pria berusia 30 tahun bersedia membayar ke suatu perusahaan sebesar X setiap tahun jika masih hidup selama 20 tahun mulai usia 35. Untuk pengembaliannya, perusahaan akan membayar Rp.50.000.000,- tiap tahun selama ia masih hidup mulai usia 60. Jika suku bunga yang digunakan adalah 5\%, tentukan X.

7. Tentukan nilai sekarang dari sebuah janji untuk membayar seseorang wanita berusia 25 tahun sebesar Rp.30.000.000,- selama 15 tahun yang diikuti dengan pembayaran sebesar Rp.25.000.000,- untuk seterusnya, jika pembayaran dilakukan selama wanita itu masih hidup dan dilakukan mulai usia 26 dan suku bunga yang ditetapkan adalah $6 \%$.

8. Tentukan nilai sekarang dari sebuah janji untuk membayar, jika masih hidup, seseorang pria berusia 23 tahun sebesar Rp.2.500.000,- tiap tahun selama 12 tahun yang ditutup dengan pembayaran sebesar Rp.25.000.000,- jika pembayaran pertama dilakukan akhir tahun ini dan suku bunga yang ditetapkan adalah 5\%. 


\section{\begin{tabular}{l|l} 
Pengantar Matematika Aktuaria & 2018
\end{tabular}}

\section{BAB VI}

\section{ASURANSI JIWA DISKRIT}

Asuransi berasal dari kata insurance yang merupakan jaminan (kepastian) menerima sesuatu (uang) atas suatu kejadian yang merugikan secara keuangan. Misalnya, meninggalnya seseorang yang merupakan sumber penghasilan keluarga, kehilangan mobil, kehilangan toko karena terbakar, cacat yang menghalangi bekerja, dll. Beban kerugian yang diderita seseorang (satu individu) itu ditanggung secara kolektif oleh peserta asuransi lain. Oleh karena itu, pengelolaan asuransi dilakukan melalui suatu lembaga keuangan (perusahaan asuransi). Berbeda dengan assurance yang bermakna menjamin sesuatu yang telah terjadi, insurance menjamin sesuatu yang belum atau akan terjadi.

Skema hubungan antara perusahaan dan individu-individu ini bisa dilihat pada gambar berikut

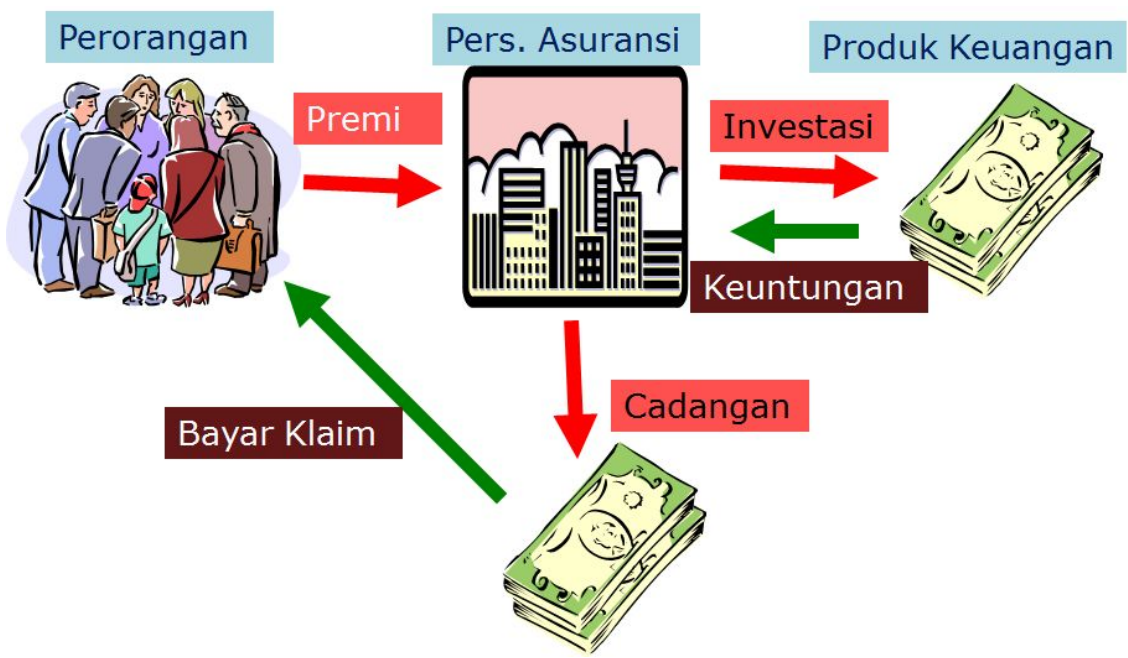

Gambar 2. Skema Pengelolaan Asuransi 


\section{\begin{tabular}{l|l} 
Pengantar Matematika Aktuaria & 2018
\end{tabular}}

Dalam pengelolaan ini, agar memperoleh keuntungan, suatu perusahaan asuransi harus memiliki kemampuan:

1) Membagi beban kerugian secara merata kepada setiap individu yang ikut asuransi, dalam hal ini menentukan premi yang tepat

2) Melakukan kegiatan operasional perusahaan secara optimum dan aman. Kegiatan operasional ini meliputi pembuatan produk asuransi beserta preminya, memilih investasi, mengatur cadangan, biaya operasional dan non-operasional.

Selain asuransi jiwa, dimana objek asuransinya adalah kehidupan, dikenal juga dua jenis asuransi lain, yaitu:

a. Asuransi non jiwa (non-life insurance)

Objek dalam asuransi ini dapat berupa

1. properti seperti rumah, toko, pabrik, dll.

2. kesehatan

3. kendaraan

4. liabilitas seperti tabungan, deposito, atau produk keuangan lain.

b. Reasuransi (reinsurance)

Objek dalam asuransi ini adalah perusahaan asuransi untuk menjamin kemampuan perusahaan tersebut dalam melayani nasabah atau kliennya. 


\section{\begin{tabular}{l|l} 
Pengantar Matematika Aktuaria & 2018
\end{tabular}}

Dengan menjadikan kehidupan sebagai objek, ada beberapa karakteristik asuransi jiwa yang tidak dimiliki oleh asuransi jenis lain, yaitu:

1. Kejadian yang diansuransikan adalah sesuatu yang pasti dan peluang terjadinya meningkat dari tahun ke tahun.

2. Bukan peluang kematian yang diasuransikan, tetapi kematian sebelum waktunya.

3. Tidak ada kemungkinan terjadi sebagian. Karena itu, semua polis adalah polis dibayar tunai.

Sebelum kita mengenal lebih jauh tentang asuransi jiwa, ada baiknya kita mengenal beberapa istilah dalam asuransi jiwa.

a. Polis (Policy)

Polis adalah perjanjian/kontrak antara peserta asuransi dengan perusahaan asuransi. Dalam polis ini dicantumkan nama peserta dan perusahaan, jenis asuransi, besarnya benefit, jangka waktu, dan syarat/ketentuan asuransi lainnya.

b. Premi (Premium)

Premi adalah nilai pembayaran yang dilakukan peserta asuransi untuk setiap periode yang disepakati. Berdasarkan cara pembayaran, jenisnya ada dua yaitu premi tunggal (dibayar satu kali saja) dan premi berkala (dibayar secara periodik: tahunan, semesteran, tiga bulanan, bulanan, dll.).

Kemudian, karena penentuan premi seharusnya dilakukan/ditentukan dari hasil investasi dikurang biaya operasional, maka berdasarkan 92 


\section{\begin{tabular}{l|l} 
Pengantar Matematika Aktuaria & 2018
\end{tabular}}

perhitungannya, premi dibedakan menjadi premi kotor (gross premium) dan premi bersih (net premium).

i. Premi bersih

Premi bersih adalah premi yang ditentukan tanpa mengikutsertakan hasil investasi dan biaya operasional, tetapi hanya mempertimbangkan empat faktor, yaitu:

- usia dan jenis kelamin

- nilai benefit

- peluang kematian.

- tingkat bunga

ii. Premi kotor

Premi kotor adalah premi bersih ditambah suatu jumlah tertentu yang ditentukan berdasarkan biaya operasional, laju pengunduran diri, hasil investasi, dll. Pada kenyataannya, premi inilah yang ditanggung oleh peserta asuransi. Tentu saja setiap perusahaan punya prinsip pengelolaan sendiri sehingga antar perusahaan dimungkinkan perbedaan premi kotor untuk asuransi yang sama.

Premi yang akan dibicarakan selanjutnya adalah premi bersih karena bersifat lebih umum tanpa kita perlu tahu bagaimana operasional suatu atau semua perusahaan asuransi. 


\section{\begin{tabular}{l|l} 
Pengantar Matematika Aktuaria & 2018
\end{tabular}}

c. Manfaat (Benefit)

Benefit adalah nilai jaminan/pertanggungan yang akan diterima peserta

jika peristiwa yang tercantum pada polis terjadi. Dalam hal asuransi

jiwa adalah kematian peserta.

PT. Asuransi Allianz Life Indonesia

Allianz (III)

Asuransi Syariah : AlliSya Protection Plus

Dipersiapkan untuk : Peserta

$\begin{array}{lll}\text { Nama Tertanggung } & : \text { Peserta } \\ \text { Tanggal Lahir } & : \text { 03-03-1982 (30 thn) } \\ \text { Jenis Kelamin } & : \text { Pria } \\ \text { Tanggal ilustrasi } & : \text { 06-07-2012 } \\ \text { Asumsi cuti premi } & : \text { Bulanan } \\ \text { Cara Bayar } & : \text { Rupiah } \\ \text { Mata Uang } & : \text {. } & \\ \text { Kelas pekerjaan } & : & 350,000 \\ \text { Premi Berkala } & : & \\ \text { Top Up Berkala } & : & 9,000 \\ \text { Bea Materai } & : & \end{array}$

\begin{tabular}{|c|c|c|c|c|}
\hline Alokasi Dana Investasi (\%) & & & & \\
\hline AlliSya Rupiah Equity Fund & 100 & & & \\
\hline & & & Uang Pertanggungan & $\begin{array}{c}\text { Tabarru } \\
\text { Per Bulan *) }\end{array}$ \\
\hline Asuransi Dasar & & & $\underline{333,333,334}$ & 48,333 \\
\hline Asuransi Tambahan & Premi & Jangka Waktu & & \\
\hline TERM LIFE & 0 & 40 & $\underline{666,666,666}$ & 96,667 \\
\hline Ringkasan Manfaat & & & & \\
\hline $\begin{array}{l}\text { AlliSya Protection Plus } \\
\text { ASP0AIDR }\end{array}$ & $\begin{array}{l}\text { Bila Tertangg } \\
\text { Investasi. } \\
\text { Bila Tertang } \\
\text { bayarkan ac }\end{array}$ & $\begin{array}{l}\text { up sampai usia } 100 \\
\text { eninggal dunia se } \\
\text { lai Investasi }+10\end{array}$ & $\begin{array}{l}\text { tahun, Manfaat yang dibayar } \\
\text { selum mencapai usia } 100 \\
\% \text { UP. }\end{array}$ & $\begin{array}{l}\text { adalah sebesar Nilai } \\
\text { n, Manfaat yang di }\end{array}$ \\
\hline TERM LIFE & $\begin{array}{l}\text { Manfaat aka } \\
\text { sebelum me }\end{array}$ & $\begin{array}{l}\text { rkan bila Tertangs } \\
\text { sia } 70 \text { tahun. }\end{array}$ & Ing meninggal dunia kare & kit atau kecelakaan \\
\hline
\end{tabular}

Gambar 3. Contoh Polis Asuransi Jiwa 


\section{\begin{tabular}{l|l} 
Pengantar Matematika Aktuaria & 2018
\end{tabular}}

\section{A. Jenis-jenis Asuransi Jiwa}

1. Berdasarkan jangka waktu

a. Asuransi jiwa berjangka $\mathrm{n}$ tahun

Pada asuransi ini, benefit akan dibayarkan jika peserta asuransi meninggal dalam waktu $\mathrm{n}$ tahun semenjak polis diterbitkan. Jika peserta asuransi masih hidup setelah $\mathrm{n}$ tahun, maka ia tidak akan memperoleh apa-apa.

Asuransi berjangka ini memiliki tiga variasi berkaitan dengan benefit, yaitu:

1) Nilai benefit tetap selama jangka waktu tersebut.

2) Nilai benefit meningkat.

Misalnya Rp.50.000.000,- pada tahun I dan bertambah setiap tahun sampai Rp.250.000.000,- pada akhir tahun ke-n (akhir jangka waktu polis).

3) Nilai benefit menurun.

Misalnya Rp.250.000.000,- pada tahun I dan menurun setiap tahun sampai Rp.50.000.000,- pada akhir tahun ke-n (akhir jangka waktu polis).

b. Asuransi dwiguna $\mathrm{n}$ tahun

Asuransi ini hampir sama dengan asuransi berjangka. Selain benefit akan dibayarkan jika peserta meninggal dalam $\mathrm{n}$ tahun, peserta juga akan menerima endowmen jika masih hidup setelah $\mathrm{n}$ tahun tersebut. 


\section{Pengantar Matematika Aktuaria 2018}

c. Asuransi jiwa seumur hidup

Pada asuransi ini, pembayaran benefit bersifat pasti karena masa pertanggungan tidak terbatas. Artinya, peserta akan memperoleh benefit kapan pun yang bersangkutan meninggal.

2. Berdasarkan persepsi waktu (pembayaran benefit dan premi)

a. Asuransi jiwa diskrit

Pada asuransi ini, waktu dianggap diskrit sehingga benefit hanya bisa dibayarkan pada akhir tahun kematian. Misalnya, jika meninggal pada tanggal 2 Juli 2012, maka benefit akan dibayarkan pada tanggal 31 Desember 2012 atau tanggal akhir tahun yang disepakati.

b. Asuransi jiwa kontinu

Pada asuransi ini, waktu dianggap kontinu sehingga benefit bisa dibayarkan dalam jangka waktu yang tidak lama setelah kematian. Misalnya, jika meninggal pada tanggal 2 Juli 2012, maka benefit akan dibayarkan segera dalam waktu yang tidak lama setelah tanggal tersebut.

\section{B. Asuransi jiwa diskrit.}

Berikut akan kita turunkan formula penghitungan benefit pada asuransi jiwa dengan persepsi waktu adalah diskrit. 


\section{\begin{tabular}{l|l} 
Pengantar Matematika Aktuaria & 2018
\end{tabular}}

1) Asuransi berjangka $n$ tahun.

Misalkan nilai sekarang dari benefit sebesar 1 rupiah untuk seseorang berusia $\mathrm{x}$ untuk jangka waktu pertanggungan $\mathrm{n}$ tahun dilambangkan dengan $\mathrm{A}_{\mathrm{x}: \mathrm{n}]}^{1}$ dimana x menunjukkan usia peserta saat mulai ikut asuransi dan n menunjukkan jangka waktu pertanggungan.

Perhatikan bahwa peluang terjadinya pembayaran benefit tergantung pada terjadinya kematian dari orang tersebut (ada peluang terjadi/tidak terjadinya pembayaran) sehingga perhitungan nilai sekarang dan peluang pembayaran premi dapat ditabelkan sebagai berikut:

Tabel 17. Nilai Sekarang dari Asuransi

\begin{tabular}{|c||c|c|c|}
\hline $\begin{array}{c}\text { Meninggal } \\
\text { pada tahun }\end{array}$ & $\begin{array}{c}\text { Besar } \\
\text { pembayaran }\end{array}$ & Nilai Sekarang & $\begin{array}{c}\text { Peluang terjadinya } \\
\text { pembayaran }\end{array}$ \\
\hline I & 1 & $\mathrm{v}^{1}$ & ${ }_{1} \mathrm{q}_{\mathrm{x}}$ \\
\hline II & 1 & $\mathrm{v}^{2}$ & ${ }_{1} \mathrm{p}_{\mathrm{x} 1} \mathrm{q}_{\mathrm{x}+1}$ \\
\hline III & 1 & $\mathrm{v}^{3}$ & ${ }_{2} \mathrm{p}_{\mathrm{x} 1} \mathrm{q}_{\mathrm{x}+2}$ \\
\hline$\ldots$ & $\ldots$ & $\ldots$ & ${ }_{\ldots}$ \\
\hline ke-n & 1 & $\mathrm{v}^{\mathrm{n}}$ & ${ }_{\mathrm{n}-1} \mathrm{p}_{\mathrm{x} 1} \mathrm{q}_{\mathrm{x}+\mathrm{n}-1}$ \\
\hline
\end{tabular}

Selanjutnya, nilai sekarang dari semua pembayaran premi tersebut adalah

$$
\begin{aligned}
\mathrm{A}_{\mathrm{x}: \mathrm{n}}^{1} & =\mathrm{v}^{1}{ }_{0} \mathrm{p}_{\mathrm{x} 1} \mathrm{q}_{\mathrm{x}}+\mathrm{v}^{2}{ }_{1} \mathrm{p}_{\mathrm{x} 1} \mathrm{q}_{\mathrm{x}+1}+\ldots+\mathrm{v}^{\mathrm{n}}{ }_{\mathrm{n}-1} \mathrm{p}_{\mathrm{x} 1} \mathrm{q}_{\mathrm{x}+\mathrm{n}-1} \\
& =\sum_{\mathrm{k}=0}^{\mathrm{n}-1} \mathrm{v}^{\mathrm{k}+1}{ }_{\mathrm{k}} \mathrm{p}_{\mathrm{x} 1} \mathrm{q}_{\mathrm{x}+\mathrm{k}}=\sum_{\mathrm{k}=0}^{\mathrm{n}-1} \mathrm{v}^{\mathrm{k}+1} \frac{1_{\mathrm{x}+\mathrm{k}}}{1_{\mathrm{x}}} \frac{\mathrm{d}_{\mathrm{x}+\mathrm{k}}}{1_{\mathrm{x}+\mathrm{k}}} \\
& =\sum_{\mathrm{k}=0}^{\mathrm{n}-1} \frac{\mathrm{v}^{\mathrm{x}+\mathrm{k}+1} \mathrm{~d}_{\mathrm{x}+\mathrm{k}}}{\mathrm{v}^{\mathrm{x}} 1_{\mathrm{x}}} \\
& =\sum_{\mathrm{k}=0}^{\mathrm{n}-1} \frac{\mathrm{C}_{\mathrm{x}+\mathrm{k}}}{\mathrm{D}_{\mathrm{x}}}=\frac{M_{\mathrm{x}}-\mathrm{M}_{\mathrm{x}+\mathrm{n}}}{\mathrm{D}_{\mathrm{x}}}
\end{aligned}
$$




\section{\begin{tabular}{l|l} 
Pengantar Matematika Aktuaria & 2018
\end{tabular}}

Jadi, secara komutasi, kita peroleh persamaan

$$
A_{x: n}^{1}=\frac{M_{x}-M_{x+n}}{D_{x}}
$$

2) Asuransi dwiguna $n$ tahun

Merupakan gabungan dari asuransi berjangka $\mathrm{n}$ tahun dengan endowmen pada akhir jangka waktu.

Misalkan nilai sekarang dari benefit atau endowmen sebesar 1 rupiah untuk seseorang berusia $\mathrm{x}$ untuk jangka waktu $\mathrm{n}$ tahun dilambangkan dengan $A_{x: \bar{n} \mid}$, maka kita peroleh persamaan

$$
A_{x: n]}=\frac{M_{x}-M_{x+n}+D_{x+n}}{D_{x}}
$$

3) Asuransi seumur hidup

Misalkan nilai sekarang dari benefit sebesar 1 rupiah untuk seseorang berusia $x$ untuk jangka waktu seumur hidup dilambangkan dengan $A_{x}$, maka kita peroleh persamaan

$$
A_{x}=\frac{M_{x}}{D_{x}}
$$

Selain itu juga dikenal asuransi jiwa yang ditunda m tahun dengan formulasi berikut: 


\section{\begin{tabular}{l|l} 
Pengantar Matematika Aktuaria & 2018
\end{tabular}}

$$
\begin{aligned}
& { }_{m} \mid A_{x}=\frac{M_{x+m}}{D_{x}} \\
& { }_{m} \mid A_{x: n}^{1}=\frac{M_{x+m}-M_{x+m+n}}{D_{x}} \\
& { }_{m} \mid A_{x: n}=\frac{M_{x+m}-M_{x+m+n}+D_{x+m+n}}{D_{x}}
\end{aligned}
$$

Pengertian ditunda ini tidak berarti penangguhan atas pertanggungan, tapi lebih banyak digunakan untuk asuransi dengan benefit berbeda yang diikuti oelh seseorang. Misalnya, asuransi dengan benfit Rp.500.000.000,untuk 10 tahun pertama dan Rp.1.000.000.000,- untuk 10 tahun berikutnya. Dalam perhitungan nantinya benefit kedua tadi diasumsikan sebagai asuransi yang ditunda 10 tahun.

\section{Kaitan Asuransi Jiwa dengan Anuitas}

1. Asuransi Seumur Hidup

Kita tahu bahwa

$$
\begin{aligned}
C_{x} & =v^{x+1} d_{x}=v^{x+1}\left(1_{x}-1_{x+1}\right) \\
& =v\left(v^{x} 1_{x}\right)-v^{x+1} 1_{x+1} \\
& =v D_{x}-D_{x+1}
\end{aligned}
$$

sehingga

$$
\begin{aligned}
& C_{x+1}=v^{x+1}-D_{x+2} \\
& \cdots \\
& C_{x+k}=v D_{x+k}-D_{x+k+1} \\
& C_{\omega}=v_{\omega}-0
\end{aligned}
$$

karena $\mathrm{D}_{\omega+1}=0$ 


\section{\begin{tabular}{l|l} 
Pengantar Matematika Aktuaria & 2018
\end{tabular}}

Selanjutnya, kita peroleh

$$
\begin{aligned}
\mathrm{C}_{\mathrm{x}}+\mathrm{C}_{\mathrm{x}+1}+. .+\mathrm{C}_{\omega} & =\left(\mathrm{vD}_{\mathrm{x}}-\mathrm{D}_{\mathrm{x}+1}\right)+\left(\mathrm{vD}_{\mathrm{x}+1}-\mathrm{D}_{\mathrm{x}+2}\right)+. .+\left(\mathrm{vD}_{\omega}-0\right) \\
\mathrm{M}_{\mathrm{x}} & =\mathrm{v}\left(\mathrm{D}_{\mathrm{x}}+\mathrm{D}_{\mathrm{x}+1}+. .+\mathrm{D}_{\omega}\right)-\left(\mathrm{D}_{\mathrm{x}+1}+\mathrm{D}_{\mathrm{x}+2}+. .+\mathrm{D}_{\omega}\right)
\end{aligned}
$$

yang akan memberikan

$$
\mathrm{M}_{\mathrm{x}}=\mathrm{vN}_{\mathrm{x}}-\mathrm{N}_{\mathrm{x}+1}
$$

Akibatnya, jika persamaan di atas dimasukkan ke rumus nilai sekarang benefit asuransi seumur hidup, maka kita peroleh

$$
A_{x}=\frac{M_{x}}{D_{x}}=\frac{v_{x}-N_{x+1}}{D_{x}}=v \frac{N_{x}}{D_{x}}-\frac{N_{x+1}}{D_{x}}
$$

sehingga

$$
A_{x}=v a_{x}-a_{x}
$$

Selanjutnya, kita bisa mengganti salah satu anuitas sehingga diperoleh

$$
\begin{aligned}
& \mathrm{A}_{\mathrm{x}}=\mathrm{va}_{\mathrm{x}}-\mathrm{a}_{\mathrm{x}} \\
& \mathrm{A}_{\mathrm{x}}=\mathrm{va}_{\mathrm{x}}-\left(\mathrm{a}_{\mathrm{x}}-1\right) \\
& \mathrm{A}_{\mathrm{x}}=(\mathrm{v}-1) \mathrm{a}_{\mathrm{x}}+1 \\
& \mathrm{~A}_{\mathrm{x}}=-\mathrm{da}_{\mathrm{x}}+1 \\
& \mathrm{~A}_{\mathrm{x}}+\mathrm{da}_{\mathrm{x}}=1
\end{aligned}
$$

2. Asuransi Berjangka $\mathrm{n}$ tahun

Dengan cara yang sama, akan diperoleh

$$
\mathrm{A}_{\mathrm{x}: \mathrm{n}]}^{1}=\mathrm{va}_{\mathrm{x}: \mathrm{n}}-\mathrm{a}_{\mathrm{x}: \mathrm{n}}
$$




\section{\begin{tabular}{l|l} 
Pengantar Matematika Aktuaria & 2018
\end{tabular}}

\section{Premi Tunggal dan Tahunan}

Premi tunggal biasanya hanya dilambangkan dengan $\mathrm{P}$, sementara premi tahunan diberi lambang khusus untuk membedakan jenis asuransinya.

Contoh:

\begin{tabular}{|c|l|}
\hline Lambang & \multicolumn{1}{|c|}{ Definisi } \\
\hline $\mathrm{P}_{\mathrm{x}}$ & $\begin{array}{l}\text { Premi tahunan untuk asuransi seumur hidup oleh seseorang } \\
\text { berusia x dengan benefit 1 rupiah }\end{array}$ \\
\hline${ }_{\mathrm{m}} \mathrm{P}_{\mathrm{x}}$ & $\begin{array}{l}\text { Premi tahunan yang dibayar m kali untuk asuransi seumur } \\
\text { hidup oleh seseorang berusia x dengan benefit 1 rupiah }\end{array}$ \\
\hline $\mathrm{P}_{\mathrm{x}: \mathrm{n}}^{1}$ & $\begin{array}{l}\text { Premi tahunan untuk asuransi berjangka } \mathrm{n} \text { tahun oleh } \\
\text { seseorang berusia } \mathrm{x} \text { dengan benefit 1 rupiah }\end{array}$ \\
\hline${ }_{\mathrm{m}} \mathrm{P}_{\mathrm{x}: \mathrm{n}}$ & $\begin{array}{l}\text { Premi tahunan yang dibayar m kali untuk asuransi dwiguna } \mathrm{n} \\
\text { tahun oleh seseorang berusia x dengan benefit 1 rupiah }\end{array}$ \\
\hline
\end{tabular}

Dengan membentuk persamaan nilai, kita bisa menghitung premi tahunan tersebut dalam notasi komutasi berikut:

$$
\begin{aligned}
& P_{x}=\frac{M_{x}}{N_{x}} \\
& { }_{m} P_{x}=\frac{M_{x}}{N_{x}-N_{x+m}} \\
& P_{x: n}^{1}=\frac{M_{x}-M_{x+n}}{N_{x}-N_{x+n}} \\
& { }_{m} P_{x: n}=\frac{M_{x}-M_{x+n}+D_{x+n}}{N_{x}-N_{x+m}}
\end{aligned}
$$

\section{Contoh soal}

1. Hitunglah premi tahunan untuk asuransi dengan benefit Rp.500.000.000,pada suku bunga 5\% untuk seorang laki-laki berusia 25 tahun untuk:

a. asuransi seumur hidup 


\section{\begin{tabular}{l|l} 
Pengantar Matematika Aktuaria & 2018
\end{tabular}}

b. asuransi seumur hidup, 15 kali pembayaran

c. asuransi berjangka sampai usia 30

d. asuransi dwiguna sampai usia 65, 20 kali pembayaran.

Jawab.

a. Asuransi seumur hidup

$x=25$

Nilai sekarang premi $=$ Nilai sekarang asuransi

$\mathrm{P}_{25} \mathrm{a}_{25}=500.000 .000 \mathrm{~A}_{25}$

$\mathrm{P}_{25}=500.000 .000 \frac{\mathrm{A}_{25}}{\mathrm{a}_{25}}$

$$
=500.000 .000 \frac{\mathrm{M}_{25}}{\mathrm{~N}_{25}}
$$

$\approx$ Rp.2.803.480,-

b. Asuransi seumur hidup, 15 kali pembayaran

Nilai sekarang premi $=$ Nilai sekarang asuransi

$$
\begin{aligned}
{ }_{15} \mathrm{P}_{25} \quad \mathrm{a}_{25: 15} & =500.000 .000 \mathrm{~A}_{25} \\
{ }_{15} \mathrm{P}_{25} \quad & 500.000 .000 \frac{\mathrm{A}_{25}}{\mathrm{a}_{25: 15}} \\
& =500.000 .000 \frac{\mathrm{M}_{25}}{\mathrm{~N}_{25}-\mathrm{N}_{40}} \\
& \approx \text { Rp.4.856.969,- }
\end{aligned}
$$

c. Berjangka sampai usia 30

Nilai sekarang premi $=$ Nilai sekarang asuransi 


\section{Pengantar Matematika Aktuaria 2018}

$$
\begin{aligned}
\mathrm{P}_{25: 5 \mid}^{1} \mathrm{a}_{25: 5} & =500.000 .000 \mathrm{~A}_{25: 5}^{1} \\
\mathrm{P}_{25: 5}^{1} & =500.000 .000 \frac{\mathrm{A}_{25: 5}^{1}}{\mathrm{a}_{25: 5}} \\
& =500.000 .000 \frac{\mathrm{M}_{25}-\mathrm{M}_{30}}{\mathrm{~N}_{25}-\mathrm{N}_{30}} \\
& \approx \text { Rp.378.597,- }
\end{aligned}
$$

d. Dwiguna sampai usia 65, 20 kali pembayaran

Nilai sekarang premi $=$ Nilai sekarang asuransi

$$
\begin{aligned}
{ }_{20} \mathrm{P}_{25: \overline{40}} \mathrm{a}_{25: \overline{20}} & =500.000 .000 \mathrm{~A}_{25: \overline{40}} \\
{ }_{20} \mathrm{P}_{25: \overline{40}} & =500.000 .000 \frac{\mathrm{A}_{25: \overline{40}}}{\mathrm{a}_{25: \overline{20}}} \\
& =500.000 .000 \frac{\mathrm{M}_{25}-\mathrm{M}_{65}+\mathrm{D}_{65}}{\mathrm{~N}_{25}-\mathrm{N}_{45}} \\
& \approx \text { Rp.6.258.417,- }
\end{aligned}
$$

2. Seorang perempuan berusia 37 mengikuti asuransi jiwa berjangka 20 tahun semenjak 7 tahun yang lalu. Jika premi tahunannya adalah Rp.4.142.753,-, berapa nilai benefitnya pada suku bunga 6\%? Jawab.

Diketahui $\quad \mathrm{x}=30, \mathrm{n}=20,{ }_{20} \mathrm{P}_{30: 20}^{1}=4.142 .753$

Persamaan nilai:

Nilai sekarang benefit $=$ Nilai sekarang anuitas premi

$$
\mathrm{X} \quad \mathrm{A}_{30: \overline{20}}^{1}={ }_{20} \mathrm{P}_{30: \overline{20}}^{1} \mathrm{a}_{30: \overline{20}}
$$




\section{Pengantar Matematika Aktuaria 2018}

$$
\begin{aligned}
X & =4.142 .753 \frac{\mathrm{N}_{30}-\mathrm{N}_{50}}{\mathrm{M}_{30}-\mathrm{M}_{50}} \\
& \approx \text { Rp.4.000.000.000,- }
\end{aligned}
$$

3. Sebuah polis diterbitkan untuk seorang laki-laki berusia 32 tahun untuk 18 kali pembayaran premi. Didalam polis itu dicantumkan bahwa :

a. Jika ia meninggal sebelum usia 65 , maka benefit adalah Rp.250.000.000,-

b. Jika ia meninggal setelah usia 65, maka benefit adalah Rp.150.000.000,-

Berapa nilai premi yang ia bayar pada suku bunga $5 \%$ ?

Jawab.

Misalkan premi tahunan yang dibayar adalah $\mathrm{P}_{0}$.

a. Nilai sekarang anuitas premi $=$ Nilai sekarang benefit

$$
\begin{aligned}
& \mathrm{P}_{0} \mathrm{a}_{32: \overline{18}}=250.000 .000 \mathrm{~A}_{32: \overline{33}}^{1}+150.000 .000 \quad{ }_{33} \mid \mathrm{A}_{32} \\
& \mathrm{P}_{0} \frac{\mathrm{N}_{32}-\mathrm{N}_{50}}{\mathrm{D}_{32}}=250.000 .000 \frac{\mathrm{M}_{32}-\mathrm{M}_{65}}{\mathrm{D}_{32}}+150.000 .000 \frac{\mathrm{M}_{65}}{\mathrm{D}_{32}} \\
& \mathrm{P}_{0}=\frac{250.000 .000\left(\mathrm{M}_{32}-\mathrm{M}_{65}\right)+150.000 .000 \mathrm{M}_{65}}{\mathrm{~N}_{32}-\mathrm{N}_{50}} \\
& \quad \approx \text { Rp.2.268.862,- }
\end{aligned}
$$

4. Sebuah polis diterbitkan untuk seorang wanita berusia 40 tahun dengan benefit Rp.500.000.000,- untuk 10 tahun dan Rp.300.000.000,- untuk 15 tahun berikutnya. Jika suku bunga $6 \%$, tentukan premi tunggalnya! Jawab.

Diketahui $\quad \mathrm{x}=40$ 


\section{\begin{tabular}{l|l} 
Pengantar Matematika Aktuaria & 2018
\end{tabular}}

$$
\begin{aligned}
& \mathrm{n}_{1}=10 \\
& \mathrm{~B}_{1}=500.000 .000 \\
& \mathrm{n}_{2}=15 \\
& \mathrm{~B}_{2}=300.000 .000
\end{aligned}
$$

Nilai sekarang premi $=$ Nilai sekarang benefit

$$
\begin{aligned}
P & =500.000 .000 A_{40: 10}^{1}+300.000 .000{ }_{10} \mid A_{40: 15}^{1} \\
= & 500.000 .000 \frac{M_{40}-M_{50}}{D_{40}}+300.000 .000 \frac{M_{50}-M_{65}}{D_{40}} \\
& \approx \text { Rp.16.806.367,- }
\end{aligned}
$$

5. Buktikan :

a. $\quad \mathrm{A}_{\mathrm{x}}-\mathrm{A}_{\mathrm{x}: \overline{10}}^{1}=\mathrm{A}_{\mathrm{x}+10}{ }_{10} \mathrm{E}_{\mathrm{x}}$

b. $\mathrm{A}_{\mathrm{x}}+\mathrm{a}_{\mathrm{x}}<\mathrm{a}_{\mathrm{x}}$

Jawab.

a. Perhatikan bahwa

$$
\begin{aligned}
A_{x}-A_{x: 10}^{1}= & \frac{M_{x}}{D_{x}}-\frac{M_{x}-M_{x+10}}{D_{x}} \\
& =\frac{M_{x+10}}{D_{x}} \\
& =\frac{M_{x+10}}{D_{x}} \frac{D_{x+10}}{D_{x+10}} \\
& =\frac{M_{x+10}}{D_{x+10}} \frac{D_{x+10}}{D_{x}} \\
& =A_{x+10} \quad 10 E_{x}
\end{aligned}
$$

b. Dengan menggunakan hubungan asuransi dengan anuitas, kita peroleh 


\section{Pengantar Matematika Aktuaria 2018}

$$
\begin{aligned}
A_{x}+a_{x} & =\left(v a_{x}-a_{x}\right)+a_{x} \\
& =v a_{x} \\
& <a_{x}
\end{aligned}
$$

6. Suatu produk asuransi diluncurkan dengan karakteristik premi tahunan untuk lima tahun pertama adalah setengah dari premi setelahnya. Jika seorang pria berusia 34 tahun mengikuti asuransi seumur hidup dengan benefit Rp.200.000.000 dan suku bunga 5\%, berapa premi yang harus ia bayar mulai tahun ke-6?

Jawab.

Misalkan premi tahun ke-6 dst. besarnya adalah $\mathrm{P}_{\mathrm{a}}$. Maka, kita peroleh persamaan nilai berikut,

$$
\begin{aligned}
& \frac{1}{2} \mathrm{P}_{\mathrm{a}_{34: 5}}+\mathrm{P}_{\mathrm{a} 5} \mid \mathrm{a}_{34}=200.000 .000 \mathrm{~A}_{34} \\
& \frac{1}{2} \mathrm{P}_{\mathrm{a}} \frac{\mathrm{N}_{34}-\mathrm{N}_{39}}{\mathrm{D}_{34}}+\mathrm{P}_{\mathrm{a}} \frac{\mathrm{N}_{39}}{\mathrm{D}_{34}}=200.000 .000 \frac{\mathrm{M}_{34}}{\mathrm{D}_{34}} \\
& \mathrm{P}_{\mathrm{a}}=\frac{200.000 .000 \mathrm{M}_{34}}{0.5\left(\mathrm{~N}_{34}-\mathrm{N}_{39}\right)+\mathrm{N}_{39}} \\
& \approx \text { Rp.2.014.854,- }
\end{aligned}
$$

\section{E. Latihan.}

1. Tunjukkan
a) $\mathrm{A}_{\mathrm{x}}=\mathrm{v}-\mathrm{d} \mathrm{\textrm {a } _ { \mathrm { x } }}$
b) $A_{x}=v\left(q_{x}+p_{x} A_{x+1}\right)$
c) $\mathrm{vq}_{\mathrm{x}}=\frac{\mathrm{A}_{\mathrm{x}}-\mathrm{vA}_{\mathrm{x}+1}}{1-\mathrm{A}_{\mathrm{x}+1}}$ 


\section{\begin{tabular}{l|l} 
Pengantar Matematika Aktuaria & 2018
\end{tabular}}

d) $P_{x}=\frac{v q_{x}+P_{x+1} a_{x}}{a_{x}}$

e) $P_{x: \bar{n} \mid}^{1}=v-\frac{a_{x: \bar{n} \mid}}{a_{x: \bar{n} \mid}}$

f) $R_{x}=v S_{x}-S_{x+1}$

g) $\mathrm{M}_{\mathrm{x}}=\mathrm{D}_{\mathrm{x}}-\mathrm{dN}_{\mathrm{x}}$

h) $\frac{A_{x}-A_{y}}{1-A_{y}}+\frac{a_{x}}{a_{y}}=\frac{P_{r} a_{r}}{A_{r}}$

i) ${ }_{r} \mid A_{x}=A_{x}-A_{x: r}^{1}$

2. Tentukan $\mathrm{A}_{55}$, jika ${ }_{35} \mathrm{P}_{20}=0,019, \mathrm{P}_{20: \overline{35} \mid}=0,028, \mathrm{P}_{20: \overline{35} \mid}^{1}=0,004$.

3. Tentukan $\mathrm{P}_{45: \overline{15}}^{1}$ jika diketahui bahwa ${ }_{15} \mathrm{P}_{45}=0,038, \mathrm{P}_{45: \overline{15}}=0,056$, dan $\mathrm{A}_{60}=0,625$.

4. Jika $A_{x}=0,013 x$ dan $\mathrm{i}=0,04$, tentukanlah $a_{x}$ dan $P_{x}$.

5. Tentukan premi tunggal pada suku bunga 5\% untuk asuransi berjangka 20 tahun dengan benefit Rp.100.000.000,-, jika pemegang polis adalah:
a. Pria berusia 29 tahun.
b. Wanita berusia 52 tahun.

6. Gambarkan dalam bentuk notasi komutasi
a. ${ }_{20} \mathrm{P}_{15}$
b. ${ }_{10} \mathrm{P}_{20: \overline{35}}$ 


\section{\begin{tabular}{l|l} 
Pengantar Matematika Aktuaria & 2018
\end{tabular}}

c. Premi tahunan untuk asuransi seumur hidup yang memberikan benefit

Rp.90.000.000,- pada akhir tahun kematian dan Rp.20.000.000,- tiap tahun selama sembilan tahun berikutnya.

7. Seorang pria A yang berusia 24 tahun membayar premi tunggal Rp.13.000.000,- untuk asuransi dengan benefit Rp.250.000.000,- jika meninggal sebelum usia 50 dan B rupiah jika meninggal setelah usia 50. Tentukan B dengan menggunakan Tabel Komutasi 6\%.

8. Buyung, yang sekarang berusia 65 tahun, telah membayar premi tahunan sebesar Rp.5.000.000,- untuk asuransi dwiguna 30 tahun dengan benefit Rp.500.000.000,- dan suatu endowmen yang jatuh tempo pada saat ini. Jika setengah dari endowmen itu ia bayarkan sebagai premi tunggal asuransi seumur hidup, berapa benefit asuransi yang akan ia ikuti? (Gunakan suku bunga 6\%).

9. Dengan Tabel Komutasi 5\%, tentukan premi tahunan yang harus dibayar seorang wanita berusia 26 tahun untuk

a. Polis asuransi seumur hidup dengan benefit 100 juta, 10 pembayaran tiap akhir tahun.

b. Polis asuransi dwiguna 20 tahun benefit 200 juta,

c. Polis asuransi berjangka 30 tahun benefit 100 juta, 5 pembayaran tiap awal tahun mulai usia 27.

10. Suatu polis diterbitkan untuk seorang pria berusia 25 tahun dengan rincian: 


\section{\begin{tabular}{l|l} 
Pengantar Matematika Aktuaria & 2018
\end{tabular}}

a. Premi dibayar tiap tahun dan premi pertama besarnya dua kali premipremi selanjutnya.

b. Masa pertanggungan 10 tahun dengan benefit Rp.100.000.000,-

c. Endowmen sebesar 5 kali premi pertama diberikan pada akhir tahun ke-10.

d. Klaim dibayar pada akhir tahun kematian

Dengan Tabel Komutasi 5\%, tentukan besarnya premi yang dibayar pada tahun kedua.

11. Misalkan $A_{x}=0,25, A_{x+20}=0,40$, dan $A_{x: 20}=0,55$.

Tentukan ${ }_{20} \mathrm{E}_{\mathrm{x}}$ dan $\mathrm{A}_{\mathrm{x}: 20}^{1} \overline{\text {. }}$

12. Misalkan $l_{x}=100-x$ untuk $x$ antara 0 sampai 100 . Jika $i=0,05$, tentukanlah $\mathrm{A}_{40}$.

13. Seorang wanita berusia 39 memiliki polis asuransi dwiguna 30 th yang diterbitkan 9 tahun lalu. Besarnya premi tahunan yang ia bayar setiap akhir tahun adalah Rp.5.000.000,-. Jika ia meninggal dalam masa pertanggungan, maka ia akan menerima benefit Rp.250.000.000,-. Berapa benefit yang akan diterima jika ia masih hidup pada akhir masa pertanggungan? (Gunakan suku bunga 6\%).

14. Suatu polis asuransi diterbitkan untuk seseorang pria berusia 40 tahun dengan benefit Rp.100.000.000,- untuk 7 tahun pertama dan Rp.50.000.000,- untuk 13 tahun berikutnya. Tentukan premi tunggal yang 


\section{Pengantar Matematika Aktuaria 2018}

mesti dibayar, jika premi itu dibayar pada usia 50 tahun. (Gunakan suku bunga $5 \%)$. 


\section{Pengantar Matematika Aktuaria 2018}

\section{BAB VII}

\section{CADANGAN PREMI BERSIH}

Kita mulai bab ini dengan mengingat tiga kategori item pada akuntansi, yaitu asset, liabilitas, dan ekuitas. Asset meliputi apa-apa yang sudah dimiliki oleh sebuah bisnis. Liabilitas meliputi apa-apa yang menjadi kewajiban bisnis tersebut. Ekuitas adalah selisih antara asset dan liabilitas. Ekuitas bisa saja negatif. Pada suatu polis asuransi, perusahaan asuransi menerima asset berupa premi dengan kewajiban (liabilitas) menyediakan dana untuk membayar benefit. Kewajiban ini diwujudkan dalam bentuk cadangan premi (premium reserve). Cadangan premi memungkinkan seorang peserta asuransi membayar premi dalam jumlah tetap, meskipun peluang kematiannya meningkat dari tahun ke tahun sementara benefit yang mesti dibayar tetap sama.

Pada bab ini cadangan premi yang dibicarakan adalah cadangan premi bersih (net premium reserve). Artinya, perhitungan hanya berdasar pada besaran premi, benefit, usia, dan suku bunga tanpa mengikutsertakan biayabiaya operasional dan non-operasional. Perhitungan juga akan bersifat individual tanpa mengikutsertakan perserta asuransi lainnya.

Ada dua cara mendasar dalam perhitungan cadangan premi bersih ini, yaitu: retrospektif dan prospektif. Meskipun secara prinsip berbeda, namun secara keuangan kedua metode ini bernilai sama. Untuk menunjukkannya perhatikan ilustrasi berikut: 


\section{Pengantar Matematika Aktuaria 2018}

Misalkan

A: Nilai akumulasi premi bersih yang telah diterima sampai sekarang.

B: Nilai sekarang dari premi bersih yang masih akan dibayar.

C: Nilai akumulasi dari benefit yang sudah disediakan sampai sekarang.

D: Nilai sekarang dari benefit yang masih akan disediakan.

Persamaan nilai untuk saat sekarang adalah:

$$
A+B=C+D
$$

Dengan menggunakan operasi aljabar sederhana, persamaan di atas bisa ditulis menjadi:

$$
A-C=D-B
$$

Ruas kiri pada persamaan di atas mewakili metode retrospektif, sementara ruas kanan mewakili metode prospektif.

\section{A. Cadangan Retrospektif.}

Metode retrospektif (retrospective method), sesuai ilustrasi sebelumnya, merujuk kepada apa yang telah dilaksanakan. Pada metode ini, cadangan premi adalah selisih dari nilai akumulasi premi sampai saat ini dikurangi nilai akumulasi benefit yang disediakan sampai saat ini. Akibatnya, cadangan yang dibentuk untuk tiga tipe dasar asuransi hanya dibedakan oleh premi bersih saja.

Misalkan kita ingin menghitung cadangan premi bersih untuk asuransi atas seseorang berusia x pada waktu t. Misalkan asuransi yang ia ikuti adalah 


\section{Pengantar Matematika Aktuaria 2018}

asuransi berjangka $\mathrm{n}$ tahun. Besar premi tahunan yang ia bayar adalah sebesar $\mathrm{P}_{\mathrm{x}: \mathrm{n}}^{1}$. Posisi transaksi dapat kita gambarkan sebagai berikut:

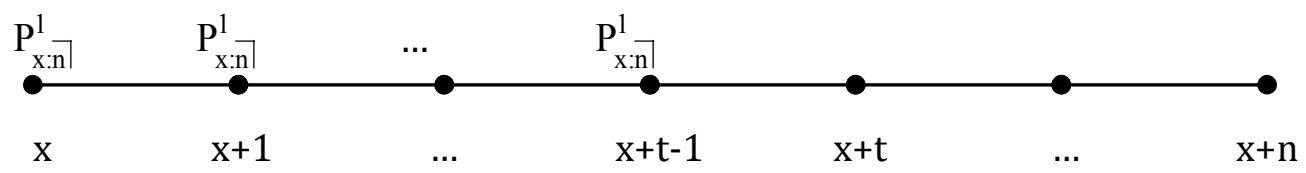

Nilai sekarang dari premi yang sudah dibayar sampai saat t adalah

$$
\mathrm{P}_{\mathrm{x}: \mathrm{n}\rceil}^{1} \mathrm{a}_{\mathrm{x}: \mathrm{t}\rceil}=\mathrm{P}_{\mathrm{x}: \mathrm{n}\rceil}^{1} \frac{\mathrm{N}_{\mathrm{x}}-\mathrm{N}_{\mathrm{x}+\mathrm{t}}}{\mathrm{D}_{\mathrm{x}}}
$$

Ingat lagi prinsip endowmen berikut.

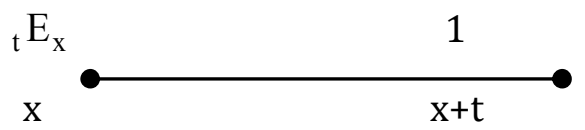

yang ekivalen dengan

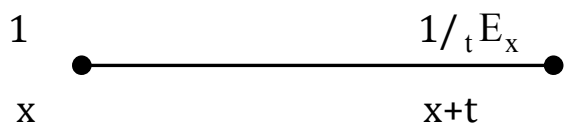

Akibatnya, nilai akumulasi dari premi yang sudah dibayar sampai saat t sama dengan nilai sekarang dibagi dengan endowmen

$$
\frac{P_{x: n}^{1} \frac{N_{x}-N_{x+t}}{D_{x}}}{{ }_{t} E_{x}}=P_{x: n}^{1} \frac{N_{x}-N_{x+t}}{D_{x}} \frac{D_{x}}{D_{x+t}}
$$

Jadi, nilai akumulasi dari premi yang sudah dibayar sampai saat $t$ adalah

$$
P_{x: n}^{1} \frac{N_{x}-N_{x+t}}{D_{x+t}}
$$




\section{\begin{tabular}{l|l} 
Pengantar Matematika Aktuaria & 2018
\end{tabular}}

Sementara nilai sekarang dari benefit sebesar 1 rupiah yang telah disediakan sampai saat $\mathrm{t}$ adalah sebesar $\mathrm{A}_{\mathrm{x}: \mathrm{t}}^{1}$

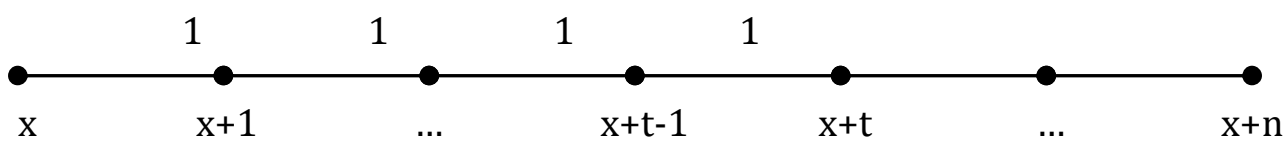

Dengan menggunakan prinsip endowmen, kita peroleh nilai akumulasi dari benefit yang sudah disediakan sampai saat $t$ adalah

$$
\frac{A_{x: t}^{1}}{{ }_{t} E_{x}}=\frac{M_{x}-M_{x+t}}{D_{x+t}}
$$

Akibatnya, kita peroleh cadangan retrospektif premi bersihnya adalah

$$
\begin{aligned}
\mathrm{t}_{\mathrm{x}: \mathrm{n}}^{1} & =\mathrm{P}_{\mathrm{x}: \mathrm{n}}^{1} \frac{\mathrm{N}_{\mathrm{x}}-\mathrm{N}_{\mathrm{x}+\mathrm{t}}}{\mathrm{D}_{\mathrm{x}+\mathrm{t}}}-\frac{M_{\mathrm{x}}-\mathrm{M}_{\mathrm{x}+\mathrm{t}}}{\mathrm{D}_{\mathrm{x}+\mathrm{t}}} \\
& =\frac{\mathrm{P}_{\mathrm{x}: \mathrm{n}}^{1}\left(\mathrm{~N}_{\mathrm{x}}-\mathrm{N}_{\mathrm{x}+\mathrm{t}}\right)-\left(\mathrm{M}_{\mathrm{x}}-\mathrm{M}_{\mathrm{x}+\mathrm{t}}\right)}{\mathrm{D}_{\mathrm{x}+\mathrm{t}}}
\end{aligned}
$$

Dengan cara yang sama, jika jenis asuransi yang diikuti adalah asuransi seumur hidup, maka cadangan premi retrospektif menjadi

$$
\begin{aligned}
\mathrm{t}_{\mathrm{x}} & =\mathrm{P}_{\mathrm{x}} \frac{\mathrm{N}_{\mathrm{x}}-\mathrm{N}_{\mathrm{x}+\mathrm{t}}}{\mathrm{D}_{\mathrm{x}+\mathrm{t}}}-\frac{\mathrm{M}_{\mathrm{x}}-\mathrm{M}_{\mathrm{x}+\mathrm{t}}}{\mathrm{D}_{\mathrm{x}+\mathrm{t}}} \\
& =\frac{P_{x}\left(N_{x}-N_{x+t}\right)-\left(M_{x}-M_{x+t}\right)}{D_{x+t}}
\end{aligned}
$$

Dan jika asuransi yang diikuti adalah asuransi dwiguna $\mathrm{n}$ tahun, maka cadangan premi retrospektif adalah

$$
\begin{aligned}
{ }_{t} V_{x: n]} & =P_{x: n} \frac{N_{x}-N_{x+t}}{D_{x+t}}-\frac{M_{x}-M_{x+t}}{D_{x+t}} \\
= & \frac{P_{x: n}\left(N_{x}-N_{x+t}\right)-\left(M_{x}-M_{x+t}\right)}{D_{x+t}}
\end{aligned}
$$




\section{Pengantar Matematika Aktuaria 2018}

Contoh

Dengan menggunakan tabel komutasi 5\%, tentukan besarnya cadangan dengan metode retrospektif pada tahun ke-15 atas polis asuransi yang diterbitkan bagi seorang pria berusia 20 tahun dengan benefit Rp.500.000.000,- untuk asuransi

a) Seumur hidup

b) Dwiguna 40 tahun dengan 20 kali pembayaran premi.

c) Berjangka 30 tahun dengan 10 kali pembayaran premi.

Jawab.

a) $P_{20}=500.000 .000 \frac{M_{20}}{N_{20}}=R p \cdot 2 \cdot 215 \cdot 777,-$

$$
{ }_{15} \mathrm{~V}_{20}=\frac{\mathrm{P}_{20}\left(\mathrm{~N}_{20}-\mathrm{N}_{35}\right)-500.000 .000\left(\mathrm{M}_{20}-\mathrm{M}_{35}\right)}{\mathrm{D}_{35}}=\mathrm{Rp} .42 .454 .061,-
$$

b) ${ }_{20} \mathrm{P}_{20: \overline{40}}=500.000 .000 \frac{\mathrm{M}_{20}-\mathrm{M}_{60}+\mathrm{D}_{60}}{\mathrm{~N}_{20}-\mathrm{N}_{40}}=$ Rp.5.992.325,-

$$
{ }_{15} \mathrm{~V}_{20: \overline{40}}=\frac{\mathrm{P}_{20: 40}\left(\mathrm{~N}_{20}-\mathrm{N}_{35}\right)-500.000 .000\left(\mathrm{M}_{20}-\mathrm{M}_{35}\right)}{\mathrm{D}_{35}}=\text { Rp.128.629.684,- }
$$

c) ${ }_{10} \mathrm{P}_{20: \overline{30 \mid}}=500.000 .000 \frac{\mathrm{M}_{20}-\mathrm{M}_{50}}{\mathrm{~N}_{20}-\mathrm{N}_{30}}=\mathrm{Rp} \cdot 1 \cdot 088.010,-$

$$
{ }_{15} \mathrm{~V}_{20: \overline{30 \mid}}=\frac{{ }_{10} \mathrm{P}_{20: 30 \mid}\left(\mathrm{N}_{20}-\mathrm{N}_{30}\right)-500.000 .000\left(\mathrm{M}_{20}-\mathrm{M}_{35}\right)}{\mathrm{D}_{35}}=\text { Rp.10.391.098,- }
$$




\section{Pengantar Matematika Aktuaria 2018}

\section{B. Cadangan Prospektif.}

Metode prospektif (prospective method), seperti ilustrasi pada awal bab ini, merujuk kepada apa yang akan terjadi di masa depan. Pada metode ini, cadangan premi adalah selisih dari nilai sekarang dari benefit yang akan disediakan dikurangi nilai sekarang dari premi yang akan dibayarkan. Berikut akan diperlihatkan formulasi cadangan premi bersih dengan metode prospektif untuk tiga jenis dasar asuransi.

1. Asuransi dwiguna $\mathrm{n}$ tahun.

Misalkan kita ingin menghitung cadangan premi bersih untuk asuransi atas seseorang berusia $\mathrm{x}$ pada waktu $\mathrm{t}$

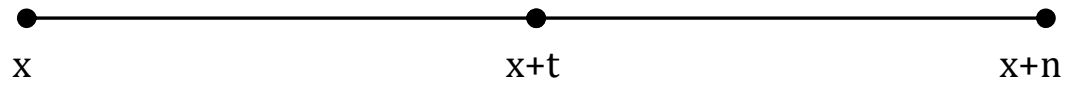

Nilai sekarang (pada usia $\mathrm{x}+\mathrm{t}$ ) dari benefit sebesar 1 rupiah yang akan disediakan sampai selesai adalah

$$
\frac{M_{x+t}-M_{x+n}+D_{x+n}}{D_{x+t}}=A_{x+t: \bar{n}-t}
$$

Sedangkan nilai sekarang dari premi yang akan datang (yang akan dibayar) adalah

$$
P_{x: n} \frac{N_{x+t}-N_{x+n}}{D_{x+t}}=P_{x: n} a_{x+t: n-t}
$$

Akibatnya, kita peroleh cadangan prospektifnya

$$
{ }_{\mathrm{t}} \mathrm{V}_{\mathrm{x}: \mathrm{n}]}=\mathrm{A}_{\mathrm{x}+\mathrm{t}: \overline{\mathrm{n}-\mathrm{t}}}-\mathrm{P}_{\mathrm{x}: \mathrm{n}]} \mathrm{a}_{\mathrm{x}+\mathrm{t} \cdot \overline{\mathrm{n}-\mathrm{t}}}
$$




\section{\begin{tabular}{l|l} 
Pengantar Matematika Aktuaria & 2018
\end{tabular}}

2. Asuransi seumur hidup

Dengan proses yang sama seperti pada asuransi dwiguna diperoleh cadangan prospektif

$$
{ }_{t} V_{x}=A_{x+t}-P_{x} a_{x+t}
$$

3. Asuransi berjangka $\mathrm{n}$ tahun.

Juga dengan proses yang sama seperti pada asuransi dwiguna diperoleh cadangan prospektif

$$
{ }_{t} V_{x: n !}^{1}=\mathrm{A}_{x+t: \bar{n}-t \mid}^{1}-P_{x: n !}^{1} a_{x+t \cdot \overline{n-t}}
$$

Contoh

Dengan menggunakan tabel komutasi 5\%, tentukan besarnya cadangan dengan metode prospektif pada tahun ke-15 atas polis asuransi yang diterbitkan bagi seorang pria berusia 20 tahun dengan benefit Rp.500.000.000,- untuk asuransi

a) Seumur hidup

b) Dwiguna 40 tahun dengan 20 kali pembayaran premi.

c) Berjangka 30 tahun dengan 10 kali pembayaran premi.

Jawab.

a) $P_{20}=500.000 .000 \frac{M_{20}}{N_{20}}=R p \cdot 2 \cdot 215.777,-$

$$
{ }_{15} \mathrm{~V}_{20}=500.000 .000 \mathrm{~A}_{35}-\mathrm{P}_{20} \mathrm{a}_{35}=\frac{500.000 .000 \mathrm{M}_{35}-\mathrm{P}_{20} \mathrm{~N}_{35}}{\mathrm{D}_{35}}
$$




\section{Pengantar Matematika Aktuaria 2018}

$=\operatorname{Rp} .42 .454 .061,-$

b) ${ }_{20} \mathrm{P}_{20: \overline{40}}=500.000 .000 \frac{\mathrm{M}_{20}-\mathrm{M}_{60}+\mathrm{D}_{60}}{\mathrm{~N}_{20}-\mathrm{N}_{40}}=$ Rp.5.992.325,-

$$
\begin{aligned}
{ }_{15} \mathrm{~V}_{20: \overline{: 40}} & =500.000 .000 \mathrm{~A}_{35: \overline{25}}-\mathrm{P}_{20: \overline{40}} \mathrm{a}_{35: \overline{25}} \\
& =\frac{500.000 .000\left(\mathrm{M}_{35}-\mathrm{M}_{60}+\mathrm{D}_{60}\right)-\mathrm{P}_{20: \overline{40 \mid}}\left(\mathrm{N}_{35}-\mathrm{N}_{40}\right)}{\mathrm{D}_{35}}
\end{aligned}
$$

$=$ Rp.128.629.684,-

c) ${ }_{10} \mathrm{P}_{20: \overline{30 \mid}}=500.000 .000 \frac{\mathrm{M}_{20}-\mathrm{M}_{50}}{\mathrm{~N}_{20}-\mathrm{N}_{30}}=\mathrm{Rp} \cdot 1 \cdot 088.010,-$

$$
{ }_{15} \mathrm{~V}_{20: \overline{30 \mid}}^{1}=500.000 .000 \mathrm{~A}_{35: 151}^{1}=\frac{500.000 .000\left(\mathrm{M}_{35}-\mathrm{M}_{50}\right)}{\mathrm{D}_{35}}=\text { Rp.10.391.098,- }
$$

\section{Latihan.}

1. Buktikan
a. ${ }_{t} V_{x}=1-\frac{a_{x+t}}{a_{x}}=\frac{A_{x+t}-A_{x}}{1-A_{x}}=A_{x+t}\left(1-\frac{P_{x}}{P_{x+t}}\right)$
b. $\quad{ }_{t} V_{x: n]}=1-\frac{a_{x+t: n-t)}}{a_{x: n}}$
c. $\quad{ }_{t} V_{x: n !}=\left(P_{x+t: \overline{n-t}}-P_{x: n}\right) a_{x+t: \overline{n-t}}$
d. $\quad{ }_{\mathrm{t}} \mathrm{V}_{\mathrm{x}}=1-\left(1-{ }_{1} \mathrm{~V}_{\mathrm{x}}\right)\left(1-{ }_{1} \mathrm{~V}_{\mathrm{x}+1}\right)\left(1-{ }_{1} \mathrm{~V}_{\mathrm{x}+2}\right) \quad\left(1-{ }_{1} \mathrm{~V}_{\mathrm{x}+\mathrm{t}-1}\right)$
e. ${ }_{1} E_{x+k}\left({ }_{k+1} V_{x}\right)={ }_{k} V_{x}+P_{x}-v q_{x+k}$

2. Dengan tabel komutasi $6 \%$, tentukan dengan metode retrospektif cadangan pada tahun ke-12 dari asuransi seumur hidup dengan benefit 


\section{Pengantar Matematika Aktuaria 2018}

Rp.1.000.000.000,- bagi seorang wanita berusia 30 tahun dengan 18 kali pembayaran premi.

3. Dengan tabel komutasi $6 \%$, tentukan besarnya cadangan premi dengan kedua metode (retrospektif dan prospektif) pada tahun ke-13 atas polis asuransi yang diterbitkan bagi seorang wanita berusia 40 tahun dengan benefit Rp.1.000.000.000,- untuk asuransi

a) Berjangka 15 tahun.

b) Seumur hidup dengan 10 kali pembayaran premi

c) Dwiguna sampai usia 70 tahun dengan 15 kali pembayaran premi.

4. Jika $\mathrm{a}_{\mathrm{x}}+\mathrm{a}_{\mathrm{x}+2 \mathrm{t}}=2 \mathrm{a}_{\mathrm{x}+\mathrm{t}}$ dan ${ }_{\mathrm{t}} \mathrm{V}_{\mathrm{x}}=1 / 4$, tentukan nilai dari ${ }_{\mathrm{t}} \mathrm{V}_{\mathrm{x}+\mathrm{t}}$ dan ${ }_{2 \mathrm{t}} \mathrm{V}_{\mathrm{x}}$.

5. Jika ${ }_{10} \mathrm{~V}_{35}=0,15$ dan ${ }_{20} \mathrm{~V}_{35}=0,354$, tentukan ${ }_{10} \mathrm{~V}_{45}$.

6. Tentukan ${ }_{10} \mathrm{~V}_{45}$ jika diketahui bahwa $\mathrm{P}_{45}=0,013, \mathrm{P}_{45: \frac{1}{20}}=0,025$, dan $\mathrm{P}_{45: \overline{20}}=$ 0,030 . 


\section{Pengantar Matematika Aktuaria 2018}

\section{BAB VIII}

\section{ASURANSI JIWA KONTINU}

Asuransi jiwa ini memandang waktu sebagai variabel yang kontinu sehingga benefit dapat dibayarkan langsung (tidak terlalu lama) setelah

waktu kematian peserta tanpa harus menunggu akhir periode seperti asuransi jiwa diskrit. Akibatnya, timbul beberapa perbedaan dengan asuransi jiwa diskrit antara lain dalam suku bunga yang dikenakan dan peluang hidup atau meninggal seseorang berusia $\mathrm{x}$.

Untuk itu, pada bagian berikut akan kita diskusikan terlebih dahulu konsep distribusi kematian (untuk variabel acak kontinu) dan fungsi survival.

\section{A. Fungsi Survival}

Misalkan X variabel acak untuk waktu kematian, maka Fungsi Distribusi Kematian

$$
F(x)=P(X \leq x)
$$

dapat diinterpretasikan sebagai peluang seseorang meninggal sebelum atau pada usia $\mathrm{x}$ dan

$$
F(20)=P(X \leq 20)
$$

menggambarkan peluang seseorang meninggal sebelum atau pada usia 20 .

Fungsi Distribusi ini memiliki beberapa karakteristik, antara lain:

a. $0 \leq \mathrm{F}(\mathrm{x}) \leq 1$

b. $\mathrm{F}(\mathrm{x})$ monoton takturun, dalam artian 


$$
\mathrm{x}_{1}<\mathrm{x}_{2} \Rightarrow \mathrm{F}\left(\mathrm{x}_{1}\right) \leq \mathrm{F}\left(\mathrm{x}_{2}\right)
$$

Misalnya $F(20) \leq F(25)$, dimana $F(20)$ berarti peluang meninggal antara usia 0 sampai 20 dan $\mathrm{F}(25)$ berarti peluang meninggal antara usia 0 sampai 25 .

c. $P(X \leq 25)=P(X \leq 20)+P(20 \leq X \leq 25)$

d. $F(X)$ kontinu dari kanan

e. $\lim _{x \rightarrow-\infty} F(x)=0$ dan $\lim _{x \rightarrow \infty} F(x)=1$

Jika $\mathrm{P}(\mathrm{X} \leq \mathrm{x})$ berarti peluang seseorang meninggal sebelum atau pada usia $\mathrm{X}$, maka $\mathrm{P}(\mathrm{X}>\mathrm{x})$ bermakna peluang seseorang masih hidup pada usia $\mathrm{x}$.

Selanjutnya, akan diperkenalkan fungsi S(x) yang disebut Fungsi Survival yang didefinisikan sebagai

$$
S(x)=P(X>x)=1-F(x)
$$

Pada Fungsi Distribusi Kematian dan Fungsi Survival ini berlaku asumsi:

$$
\begin{aligned}
& F(0)=0 \\
& S(0)=1
\end{aligned}
$$

Dengan demikian, kita bisa membicarakan peluang meninggal sebagai berikut.

Misalkan $\mathrm{x}<\mathrm{z}$. Maka peluang seseorang meninggal antara usia $\mathrm{x}$ dan $\mathrm{z}$ dengan syarat masih hidup pada usia $\mathrm{x}$ yang dilambangkan dengan $\mathrm{P}(\mathrm{x}<\mathrm{X}<\mathrm{z} \mid \mathrm{X}>\mathrm{x})$ dapat diturunkan sebagai berikut:

$$
\mathrm{P}(\mathrm{x}<\mathrm{X}<\mathrm{z} \mid \mathrm{X}>\mathrm{x})=\frac{\mathrm{P}(\mathrm{x}<\mathrm{X}<\mathrm{z})}{\mathrm{P}(\mathrm{X}>\mathrm{x})}=\frac{\mathrm{P}(\mathrm{X}<\mathrm{z})-\mathrm{P}(\mathrm{X}<\mathrm{x})}{1-\mathrm{P}(\mathrm{X}<\mathrm{x})}=\frac{\mathrm{F}(\mathrm{z})-\mathrm{F}(\mathrm{x})}{1-\mathrm{F}(\mathrm{x})}=\frac{\mathrm{S}(\mathrm{x})-\mathrm{S}(\mathrm{z})}{\mathrm{S}(\mathrm{x})}
$$




\section{\begin{tabular}{l|l} 
Pengantar Matematika Aktuaria & 2018
\end{tabular}}

Akibatnya, peluang seseorang meninggal antara usia $\mathrm{x}$ dan $\mathrm{x}+\mathrm{t}$ dengan syarat masih hidup pada usia x yang dilambangkan dengan $\mathrm{t}_{\mathrm{x}}$ dapat didefinisikan sebagai

$$
\begin{aligned}
{ }_{\mathrm{t}} \mathrm{q}_{\mathrm{x}} & =\mathrm{P}(\mathrm{x}<\mathrm{X}<\mathrm{x}+\mathrm{t} \mid \mathrm{X}>\mathrm{x}) \\
& =\frac{\mathrm{S}(\mathrm{x})-\mathrm{S}(\mathrm{x}+\mathrm{t})}{\mathrm{S}(\mathrm{x})}
\end{aligned}
$$

dan peluang seseorang berusia $x$ masih hidup setelah $t$ tahun $\left(\mathrm{t}_{\mathrm{x}}\right)$

$$
\begin{aligned}
{ }_{t} p_{x} & =1-{ }_{t} q_{x} \\
& =1-\frac{S(x)-S(x+t)}{S(x)} \\
& =\frac{S(x+t)}{S(x)}
\end{aligned}
$$

\section{B. Laju Kematian}

Berikutnya, akan didefinisikan laju kematian (force of mortality) yang dapat diartikan sebagai kecepatan peluang meninggal orang berusia x pada suatu saat. Laju kematian ini dilambangkan dengan $\mu_{\mathrm{x}}$ ditentukan melalui persamaan berikut

$$
\begin{aligned}
& \mathrm{P}(\mathrm{x}<\mathrm{X}<\mathrm{X}+\Delta \mathrm{x} \mid \mathrm{X}>\mathrm{x})=\frac{\mathrm{F}(\mathrm{x}+\Delta \mathrm{x})-\mathrm{F}(\mathrm{x})}{1-\mathrm{F}(\mathrm{x})} \\
& \lim _{\Delta \mathrm{x} \rightarrow 0} \frac{\mathrm{P}(\mathrm{x}<\mathrm{X}<\mathrm{X}+\Delta \mathrm{x} \mid \mathrm{X}>\mathrm{x})}{\Delta \mathrm{x}}=\mu_{\mathrm{x}}
\end{aligned}
$$




\section{\begin{tabular}{l|l} 
Pengantar Matematika Aktuaria & 2018
\end{tabular}}

sehingga diperoleh

$$
\begin{aligned}
\mu_{x} & =\lim _{\Delta x \rightarrow 0} \frac{F(x+\Delta x)-F(x)}{(1-F(x)) \Delta x} \\
& =\frac{1}{1-F(x)} \lim _{\Delta x \rightarrow 0} \frac{F(x+\Delta x)-F(x)}{\Delta x} \\
& =\frac{F^{\prime}(x)}{1-F(x)}
\end{aligned}
$$

Dengan subtitusi

$$
\begin{aligned}
& S(x)=1-F(x) \\
& F(x+\Delta x)=1-S(x+\Delta x)
\end{aligned}
$$

diperoleh

$$
\mu_{x}=-\frac{S^{\prime}(x)}{S(x)}
$$

Untuk memperoleh peluang hidup dan meninggal dengan menggunakan laju kematian kita lakukan proses berikut.

Pertama, integralkan kedua ruas antara $\mathrm{x}$ dan $\mathrm{x}+\mathrm{t}$ sehingga diperoleh

$$
\begin{aligned}
-\int_{x}^{x+t} \mu_{y} d y & =\int_{x}^{x+t} \frac{S^{\prime}(y)}{S(y)} d y \\
& =\int_{x}^{x+t} d \ln (S(y)) \\
& =\ln (S(x+t))-\ln (S(x)) \\
& =\ln \frac{S(x+t)}{S(x)}
\end{aligned}
$$




\section{\begin{tabular}{l|l} 
Pengantar Matematika Aktuaria & 2018
\end{tabular}}

Selanjutnya, eksponensialkan kedua ruas sehingga diperoleh

$$
\frac{\mathrm{S}(\mathrm{x}+\mathrm{t})}{\mathrm{S}(\mathrm{x})}=\mathrm{e}^{-\int_{\mathrm{x}}^{\mathrm{x}+\mathrm{t}} \mu_{\mathrm{y}} \mathrm{dy}}=\mathrm{e}^{-\int_{0}^{\mathrm{t}} \mu_{\mathrm{x}+\mathrm{s}} \mathrm{ds}}
$$

Jadi, peluang hidup seseorang berusia $\mathrm{x}$ sampai $u$ sia $\mathrm{x}+\mathrm{t}$ adalah

$$
{ }_{t} p_{x}=e^{-\int_{x}^{x+t} \mu_{y} d y}=e^{-\int_{0}^{t} \mu_{x+s} d s}
$$

Selanjutnya, dengan menurunkan kedua ruas, diperoleh

$$
\begin{aligned}
\frac{d}{d t}\left({ }_{t} q_{x}\right) & =\frac{d}{d t}\left(\frac{S(x)-S(x+t)}{S(x)}\right) \\
& =-\frac{S^{\prime}(x+t)}{S(x)} \\
& =-\frac{S^{\prime}(x+t)}{S(x+t)} \frac{S(x+t)}{S(x)} \\
& ={ }_{t} p_{x} \mu_{x+t}
\end{aligned}
$$

Ada beberapa laju kematian yang sering digunakan, diantaranya:

De Moivre (1729)

$$
\mu_{\mathrm{x}}=\frac{1}{\omega-\mathrm{x}}, 0<\mathrm{x}<\omega
$$

Gompertz (1825)

$$
\mu_{\mathrm{x}}=\mathrm{BC}^{\mathrm{x}}
$$

Mocham (1860)

$$
\mu_{\mathrm{x}}=\mathrm{A}+\mathrm{BC}^{\mathrm{x}}
$$

Weibull (1939)

$$
\mu_{\mathrm{x}}=\mathrm{kx}^{\mathrm{n}}
$$

\section{Asuransi Jiwa Kontinu}

Dalam pembentukan formulasi untuk asuransi jiwa kontinu, kita menggunakan asumsi bahwa dalam 1 tahun ditribusi peluang meninggal 


\section{\begin{tabular}{l|l} 
Pengantar Matematika Aktuaria & 2018
\end{tabular}}

seragam (uniform) dengan rasional bahwa tidak ada waktu dimana lebih banyak orang meninggal dari waktu yang lain.

Dengan asumsi ini kita bisa membuat persamaan

$$
l_{x+t}=l_{x}-t d_{x}
$$

Selanjutnya, kita peroleh peluang hidup

$$
\begin{aligned}
{ }_{t} p_{x} & =\frac{1_{x+t}}{1_{x}} \\
& =\frac{1_{x}-t d_{x}}{1_{x}} \\
& =1-t \frac{d_{x}}{1_{x}} \\
& =1-t_{x}
\end{aligned}
$$

Akibatnya, dengan asumsi seragam tersebut kedua persamaan berikut akan dipenuhi.

$$
\begin{aligned}
& { }_{\mathrm{t}} \mathrm{p}_{\mathrm{x}+\mathrm{k}}=1-\mathrm{tq}_{\mathrm{x}+\mathrm{k}} \\
& { }_{\mathrm{t}} \mathrm{q}_{\mathrm{x}+\mathrm{k}}=\mathrm{tq}_{\mathrm{x}+\mathrm{k}}
\end{aligned}
$$

Selanjutnya, akan kita turunkan nilai sekarang dari Asuransi Jiwa Kontinu. Misalkan nilai sekarang untuk asuransi jiwa kontinu seumur hidup untuk seseorang berusia x dengan benefit 1 rupiah dilambangkan dengan $\bar{A}_{x}$. 


\section{Pengantar Matematika Aktuaria 2018}

Maka,

$$
\begin{aligned}
\bar{A}_{x} & =\int_{0}^{\infty} v^{t}{ }_{t} p_{x} \mu_{x+t} d t \\
& =\int_{0}^{1} v^{t}{ }_{t} p_{x} \mu_{x+t} d t+\int_{1}^{2} v^{t}{ }_{t} p_{x} \mu_{x+t} d t+\ldots \\
& =\sum_{k=0}^{\infty} \int_{0}^{1} v^{s+k}{ }_{s+k} p_{x} \mu_{x+s+k} d s
\end{aligned}
$$

Selanjutnya, perhatikan bahwa

$$
{ }_{s+k} p_{x}=\frac{l_{x+s+k}}{l_{x}}=\frac{l_{x+s+k}}{l_{x+k}} \frac{l_{x+k}}{l_{x}}={ }_{s} p_{x+k} \times{ }_{k} p_{x}
$$

Akibatnya,

$$
\begin{aligned}
\overline{\mathrm{A}}_{\mathrm{x}} & =\sum_{\mathrm{k}=0}^{\infty} \int_{0}^{1} \mathrm{v}^{s+\mathrm{k}}\left({ }_{\mathrm{s}} \mathrm{p}_{\mathrm{x}+\mathrm{k}} \times{ }_{\mathrm{k}} \mathrm{p}_{\mathrm{x}}\right) \mu_{\mathrm{x}+\mathrm{s}+\mathrm{k}} \mathrm{ds} \\
& =\sum_{\mathrm{k}=0}^{\infty} \mathrm{v}^{\mathrm{k}+1}{ }_{\mathrm{k}} \mathrm{p}_{\mathrm{x}} \int_{0}^{1} \mathrm{v}^{\mathrm{s}-1}{ }_{\mathrm{s}} \mathrm{p}_{\mathrm{x}+\mathrm{k}} \mu_{\mathrm{x}+\mathrm{s}+\mathrm{k}} \mathrm{ds}
\end{aligned}
$$

Perhatikan bahwa bagian integral dari persamaan di atas dapat disederhanakan menjadi

$$
\begin{aligned}
\int_{0}^{1} v^{s-1}{ }_{s} p_{x+k} \mu_{x+s+k} d s & =\int_{0}^{1} v^{s-1} \frac{1_{x+s+k}}{1_{x+k}} \frac{1}{1_{x+s+k}} \frac{-d\left(1_{x+s+k}\right)}{d s} d s \\
& =-\int_{0}^{1} v^{s-1} \frac{1}{1_{x+k}} d\left(1_{x+s+k}\right)=\frac{-1}{1_{x+k}} \int_{0}^{1} v^{s-1} d\left(1_{x+k}-s d_{x+k}\right) \\
& =\frac{-1}{1_{x+k}} \int_{0}^{1} v^{s-1}\left(-d_{x+k} d s\right)=\int_{0}^{1} v^{s-1} \frac{d_{x+k}}{1_{x+k}} d s \\
& =\int_{0}^{1} v^{s-1} q_{x+k} d s
\end{aligned}
$$




\section{\begin{tabular}{l|l} 
Pengantar Matematika Aktuaria & 2018
\end{tabular}}

sehingga kita peroleh bentuk yang lebih sederhana

$$
\begin{aligned}
\bar{A}_{x} & =\sum_{k=0}^{\infty} v^{k+1}{ }_{k} p_{x} \int_{0}^{1} v^{s-1} q_{x+k} d s \\
& =\sum_{k=0}^{\infty} v^{k+1}{ }_{k} p_{x} q_{x+k} \int_{0}^{1} v^{s-1} d s \\
& =\sum_{k=0}^{\infty} v^{k+1}{ }_{k} p_{x} q_{x+k} \int_{0}^{1} e^{(s-1) \ln v} d s \\
& =\sum_{k=0}^{\infty} v^{k+1}{ }_{k} p_{x} q_{x+k}\left(\frac{1}{\ln v} e^{(s-1) \ln v}\right)_{s=0}^{s=1} \\
& =\sum_{k=0}^{\infty} v^{k+1}{ }_{k} p_{x} q_{x+k}\left(\frac{1}{\ln v}-\frac{1}{\ln v} e^{-\ln v}\right) \\
& =\sum_{k=0}^{\infty} v^{k+1}{ }_{k} p_{x} q_{x+k}\left(\frac{1}{\ln v}-\frac{1}{\ln v} \frac{1}{v}\right) \\
& =\sum_{k=0}^{\infty} v^{k+1}{ }_{k} p_{x} q_{x+k} \frac{1}{\ln v}\left(1-\frac{1}{v}\right) \\
& =\frac{-i}{\ln v} \sum_{k=0}^{\infty} v_{x}^{k+1}{ }_{k} p_{x} q_{x+k} \frac{1}{\ln v}(-i) \\
& =\frac{-i}{\ln v} \sum_{k=0}^{\infty} v^{k+1}{ }_{k} p_{x} q_{x+k} \\
&
\end{aligned}
$$

Selanjutnya, kita perkenalkan notasi baru

$$
\delta=\ln (1+\mathrm{i})=-\ln \mathrm{v}
$$

Dengan menggunakan notasi ini, kita peroleh

$$
\overline{\mathrm{A}}_{\mathrm{x}}=\frac{\mathrm{i}}{\delta} \mathrm{A}_{\mathrm{x}}
$$




\section{\begin{tabular}{l|l} 
Pengantar Matematika Aktuaria & 2018
\end{tabular}}

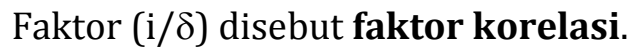

Kaitan antara $\overline{\mathrm{A}}_{\mathrm{x}}$ dan $\overline{\mathrm{a}}_{\mathrm{x}}$

Kita tahu bahwa $\bar{a}_{x}=\int_{0}^{n} v^{t}{ }_{t} p_{x} d t$

Akibatnya,

$$
\begin{aligned}
\bar{A}_{x} & =\int_{0}^{\infty} v^{t}{ }_{t} p_{x} \mu_{x+t} d t \\
& =-\int_{0}^{\infty} v \frac{1_{x+t}}{1_{x}} \frac{1}{1_{x+t}} \frac{d\left(1_{x+t}\right)}{d t} d t \\
& =-\int_{0}^{\infty} v^{t} \frac{1}{1_{x}} d\left(1_{x+t}\right) \\
& =-\left.\frac{v^{t}}{1_{x}} 1_{x+t}\right|_{t=0} ^{\infty}+\int_{0}^{\infty} \frac{1_{x+t}}{1_{x}} v^{t} \ln v d t \\
& =\frac{1_{x}}{1_{x}}+\ln v \int_{0}^{\infty} v^{t}{ }_{t} p_{x} d t \\
& =1+\ln v \bar{a}_{x}
\end{aligned}
$$

Selanjutnya, kita peroleh

$$
\overline{\mathrm{A}}_{\mathrm{x}}-\ln \mathrm{v} \overline{\mathrm{a}}_{\mathrm{x}}=1
$$

atau dalam bentuk yang lebih sederhana

$$
\overline{\mathrm{A}}_{\mathrm{x}}+\delta \overline{\mathrm{a}}_{\mathrm{x}}=1
$$

Dengan cara yang sama dengan di atas, untuk asuransi dwiguna juga dapat diperoleh kaitan antara asuransi dan anuitas berikut.

$$
\overline{\mathrm{A}}_{\mathrm{x}: \mathrm{n}}+\delta \overline{\mathrm{a}}_{\mathrm{x}: \mathrm{n}}=1
$$




\section{Pengantar Matematika Aktuaria 2018}

Contoh.

1. Dengan menggunakan $\mathrm{i}=5 \%$, tentukanlah premi tahunan untuk benefit sebesar satu milyar rupiah bagi seorang pria berusia 30 tahun jika asuransi yang diikuti berupa

a) Asuransi seumur hidup kontinu

b) Asuransi dwiguna 40 tahun dengan 5 kali pembayaran premi

Jawab.

a) Nilai sekarang dari Premi $=$ Nilai sekarang dari benefit

P. $\mathrm{P} \overline{\mathrm{a}}_{30}=1.000 .000 .000 \overline{\mathrm{A}}_{30}$

$$
\begin{gathered}
P\left(\frac{1-\overline{\mathrm{A}}_{30}}{\delta}\right)=1.000 .000 .000 \frac{\mathrm{i}}{\delta} \mathrm{A}_{30} \\
\mathrm{P}\left(\frac{1-\frac{\mathrm{i}}{\delta} \mathrm{A}_{30}}{\delta}\right)=1.000 .000 .000 \frac{\mathrm{i}}{\delta} \mathrm{A}_{30} \\
\mathrm{P}=\frac{\mathrm{P}\left(\frac{1-\frac{\mathrm{i}}{\delta} \frac{\mathrm{M}_{30}}{\mathrm{D}_{30}}}{\not D}\right)=1.000 .000 .000 \frac{\mathrm{i}}{\not} \frac{\mathrm{M}_{30}}{\mathrm{D}_{30}}}{1.000 .000 .000 \mathrm{i} \frac{\mathrm{M}_{30}}{\mathrm{D}_{30}}} \\
\approx \mathrm{Rp} .7 .537 .456,-
\end{gathered}
$$

b) Nilai sekarang dari Premi = Nilai sekarang dari benefit

$$
P \overline{\mathrm{a}}_{30: 5 \mid}=1.000 .000 .000 \overline{\mathrm{A}}_{30: 40}
$$




\section{\begin{tabular}{l|l} 
Pengantar Matematika Aktuaria & 2018
\end{tabular}}

$$
\begin{aligned}
& P\left(\frac{1-\bar{A}_{30: 51}}{\delta}\right)=1.000 .000 .000 \frac{\mathrm{i}}{\delta} \mathrm{A}_{30: 40} \\
& \mathrm{P}\left(\frac{1-\overline{\mathrm{A}}_{30: 5}}{\delta}\right)=1.000 .000 .000 \frac{\mathrm{i}}{\delta} \mathrm{A}_{30: 40} \\
& \mathrm{P}\left(\frac{\left.1-\frac{\mathrm{i}}{\delta} \frac{\mathrm{M}_{30}-\mathrm{M}_{35}+\mathrm{D}_{35}}{\mathrm{D}_{30}}\right)=1.000 .000 .000 \frac{\mathrm{i}}{\not} \frac{\mathrm{M}_{30}-\mathrm{M}_{70}+\mathrm{D}_{70}}{\mathrm{D}_{30}}}{\not}\right) \\
& \mathrm{P}=\frac{1.000 .000 .000 \mathrm{i} \frac{\mathrm{M}_{30}-\mathrm{M}_{70}+\mathrm{D}_{70}}{\mathrm{D}_{30}}}{1-\frac{\mathrm{i}}{\delta} \frac{\mathrm{M}_{30}-\mathrm{M}_{35}+\mathrm{D}_{35}}{\mathrm{D}_{30}}}
\end{aligned}
$$$$
\approx \text { Rp.44.144.631,- }
$$

2. Jika $\mu_{\mathrm{x}}=\frac{\mathrm{a}}{\mathrm{b}+\mathrm{x}}$, tentukanlah $\mathrm{S}(\mathrm{x})$

Jawab.

$$
\begin{aligned}
& \mu_{x}=-\frac{S^{\prime}(x)}{S(x)} \\
& \int \mu_{x} d x=-\int \frac{S^{\prime}(x)}{S(x)} d x \\
& \int \mu_{x} d x=-\int d(\ln S(x)) \\
& \int \frac{a}{b+x} d x=-\ln S(x) \\
& a \ln (b+x)+\ln C=-\ln S(x) \\
& \ln C(b+x)^{a}=-\ln S(x)
\end{aligned}
$$




\section{\begin{tabular}{l|l} 
Pengantar Matematika Aktuaria & 2018
\end{tabular}}

$$
S(x)=\frac{1}{C(b+x)^{a}}=\frac{K}{(b+x)^{a}}
$$

Karena $\mu_{0}=1$, maka diperoleh

$$
1=\frac{K}{(b+0)^{a}} \Rightarrow K=b^{a}
$$

sehingga

$$
S(x)=\frac{b^{a}}{(b+x)^{a}}=\left(\frac{b}{b+x}\right)^{a}
$$

3. Jika $S(x)=e^{\frac{-x^{3}}{2}}$, tentukanlah $\mu_{x}, F(x)$, dan $F^{\prime}(x)$

Jawab :

$$
\begin{aligned}
\mu_{x} & =\frac{-S^{\prime}(x)}{S(x)} \\
& =-\frac{\frac{-3 x^{2}}{2} e^{\frac{-x^{3}}{2}}}{e^{\frac{-x^{3}}{2}}} \\
& =\frac{3 x^{2}}{2} \\
S(x) & =1-F(x) \\
F(x) & =1-S(x) \\
& =1-e^{\frac{-x^{3}}{2}} \\
F^{\prime}(x) & =-\frac{-3 x^{2}}{2} e^{\frac{-x^{3}}{2}}=\frac{3 x^{2}}{2} e^{\frac{-x^{3}}{2}}
\end{aligned}
$$

4. Seorang pria berusia 25 tahun membeli polis asuransi dwiguna 40 tahun dengan benefit 500 juta rupiah yang akan dibayarkan pada saat 


\section{\begin{tabular}{l|l} 
Pengantar Matematika Aktuaria & 2018
\end{tabular}}

kematiannya. Tentukanlah besar premi yang mesti ia bayar selama 15 tahun jika

a. Dibayar setiap awal tahun

b. Dibayar setiap akhir tahun

c. Dibayar pada waktu yang tidak ditetapkan dalam setiap tahun

Premi mana yang paling murah? (Gunakan i=5\%)

Jawab.

a. Dibayar setiap awal tahun

Nilai sekarang dari premi $=$ Nilai sekarang dari benefit

$$
\begin{aligned}
\mathrm{P} \cdot \mathrm{a}_{25: 15 \mid} & =500.000 .000 \overline{\mathrm{A}}_{25: 40} \\
\mathrm{P} & \approx \mathrm{Rp} .7 .685 .159,-
\end{aligned}
$$

b) Dibayar setiap akhir tahun

Nilai sekarang dari premi $=$ Nilai sekarang dari benefit

$$
\begin{gathered}
\mathrm{P} \cdot \mathrm{a}_{25: \overline{15} \mid}=500.000 .000 \overline{\mathrm{A}}_{25: \overline{40}} \\
\mathrm{P} \approx \mathrm{Rp} .8 .076 .514,-
\end{gathered}
$$

c) Dibayar pada waktu yang tidak ditetapkan

Nilai sekarang dari premi $=$ Nilai sekarang dari benefit

$$
\begin{gathered}
\mathrm{P} \cdot \overline{\mathrm{a}}_{25: 15 \mid}=500.000 .000 \overline{\mathrm{A}}_{25: \overline{40}} \\
\mathrm{P} \approx \mathrm{Rp} .8 .061 .360,-
\end{gathered}
$$

Jadi, premi termurah adalah premi yang dibayar pada awal tahun. 


\section{Pengantar Matematika Aktuaria 2018}

\section{Latihan}

1. Tentukan $S(x)$ jika
A. $\mu_{x}=1 /(\omega-x), 0<x<\omega$
B. $\mu_{\mathrm{x}}=\mathrm{a} /(\mathrm{b}+\mathrm{x}), \mathrm{a}, \mathrm{b}>0$.
C. $\mu_{\mathrm{x}}=\mathrm{kx}^{\mathrm{n}}$

2. Jika $S(x)=\exp \left(-x^{3} / 12\right), x \geq 0$, tentukanlah $\mu_{x}, F^{\prime}(x)$ dan $F(x)$.

3. Tentukan benefit untuk asuransi seumur hidup yang diterbitkan untuk seorang wanita berusia 25 tahun, jika premi yang dibayar adalah sebesar 2 juta rupiah selama 10 tahun efektif mulai usia 40. Benefit dibayarkan pada saat kematian. (Gunakan $\mathrm{i}=5 \%$ ).

4. Seseorang wanita berusia 30 tahun membayar 20 juta rupiah pada tahun pertama dan premi tahunan 1 juta rupiah mulai tahun berikutnya untuk sebuah polis asuransi seumur hidup. Berapa nilai polis tersebut jika asuransi dibayarkan pada saat kematian? (Gunakan $\mathrm{i}=6 \%$ ).

5. Pada $\mathrm{i}=5 \%$, tentukan premi tahunan yang harus dibayar seorang pria berusia 30 tahun untuk benefit sebesar 250 juta rupiah pada:

a. Asuransi dwiguna (diskrit) sampai usia 65 tahun, 20 pembayaran tiap awal tahun mulai usia 31.

b. Asuransi seumur hidup (kontinu), 10 pembayaran tiap akhir tahun. 


\section{\begin{tabular}{l|l} 
Pengantar Matematika Aktuaria & 2018
\end{tabular}}

\section{DAFTAR PUSTAKA}

Frensidy, Budi (2006). Matematika Keuangan ed. 2. Salemba Empat. Jakarta.

Gerber, Hans U. (1997). Life Insurance Mathematics. Springer. Berlin.

Larson, Robert E. (1951). Life Insurance Mathematics. John Wiley. New York.

OLICD Center Actuary Team (1995). Actuarial Mathematics in a Plain Manner. OLIS. Tokyo.

Promislow, S. David (2010). Fundamentals of Actuarial Mathematics 2nd. Ed. John Wiley. New York.

Veeh, Jerry A. (2005). Lecture Notes on Actuarial Mathematics.University of California. Irvine.

Zima, Petr dan Robert Brown (1996). Schaum's Outline of Mathematics of Finance 2nd Ed. McGraw-Hill. New York. 


\section{\begin{tabular}{l|l} 
Pengantar Matematika Aktuaria & 2018
\end{tabular}}

LAMPIRAN I. TABEL MORTALITAS INDONESIA 2011 (LAKI-LAKI)

\begin{tabular}{|c|c|c|c|c|c|}
\hline $\mathbf{x}$ & $\mathbf{l}_{\mathbf{x}}$ & $\mathbf{d}_{\mathbf{x}}$ & $\mathbf{p}_{\mathbf{x}}$ & $\mathbf{q}_{\mathbf{x}}$ & $\mathbf{e}_{\mathbf{x}}$ \\
\hline 0 & 100,000 & 802 & 0.99198 & 0.00802 & 73.62506 \\
\hline 1 & 99,198 & 78 & 0.99921 & 0.00079 & 73.22031 \\
\hline 2 & 99,120 & 62 & 0.99937 & 0.00063 & 72.27793 \\
\hline 3 & 99,058 & 51 & 0.99949 & 0.00051 & 71.32316 \\
\hline 4 & 99,007 & 43 & 0.99957 & 0.00043 & 70.35990 \\
\hline 5 & 98,964 & 38 & 0.99962 & 0.00038 & 69.39048 \\
\hline 6 & 98,926 & 34 & 0.99966 & 0.00034 & 68.41713 \\
\hline 7 & 98,892 & 31 & 0.99969 & 0.00031 & 67.44065 \\
\hline 8 & 98,861 & 29 & 0.99971 & 0.00029 & 66.46180 \\
\hline 9 & 98,832 & 28 & 0.99972 & 0.00028 & 65.48130 \\
\hline 10 & 98,804 & 27 & 0.99973 & 0.00027 & 64.49986 \\
\hline 11 & 98,777 & 27 & 0.99973 & 0.00027 & 63.51749 \\
\hline 12 & 98,750 & 26 & 0.99974 & 0.00026 & 62.53486 \\
\hline 13 & 98,724 & 26 & 0.99974 & 0.00026 & 61.55132 \\
\hline 14 & 98,698 & 27 & 0.99973 & 0.00027 & 60.56754 \\
\hline 15 & 98,671 & 29 & 0.99971 & 0.00029 & 59.58411 \\
\hline 16 & 98,642 & 30 & 0.99970 & 0.0003 & 58.60163 \\
\hline 17 & 98,612 & 32 & 0.99968 & 0.00032 & 57.61946 \\
\hline 18 & 98,580 & 35 & 0.99964 & 0.00036 & 56.63816 \\
\hline 19 & 98,545 & 40 & 0.99959 & 0.00041 & 55.65828 \\
\hline 20 & 98,505 & 48 & 0.99951 & 0.00049 & 54.68088 \\
\hline 21 & 98,457 & 58 & 0.99941 & 0.00059 & 53.70754 \\
\hline 22 & 98,399 & 68 & 0.99931 & 0.00069 & 52.73919 \\
\hline 23 & 98,331 & 76 & 0.99923 & 0.00077 & 51.77567 \\
\hline 24 & 98,255 & 82 & 0.99917 & 0.00083 & 50.81571 \\
\hline 25 & 98,173 & 83 & 0.99915 & 0.00085 & 49.85816 \\
\hline 26 & 98,090 & 81 & 0.99917 & 0.00083 & 48.90035 \\
\hline 27 & 98,009 & 77 & 0.99921 & 0.00079 & 47.94076 \\
\hline 28 & 97,932 & 73 & 0.99925 & 0.00075 & 46.97845 \\
\hline 29 & 97,859 & 72 & 0.99926 & 0.00074 & 46.01350 \\
\hline 30 & 97,787 & 74 & 0.99924 & 0.00076 & 45.04738 \\
\hline 31 & 97,713 & 78 & 0.99920 & 0.0008 & 44.08149 \\
\hline 32 & 97,635 & 81 & 0.99917 & 0.00083 & 43.11671 \\
\hline 33 & 97,554 & 82 & 0.99916 & 0.00084 & 42.15251 \\
\hline 34 & 97,472 & 84 & 0.99914 & 0.00086 & 41.18797 \\
\hline 35 & 97,388 & 89 & 0.99909 & 0.00091 & 40.22350 \\
\hline & & & & & \\
\hline
\end{tabular}




\section{Pengantar Matematika Aktuaria 2018}

\begin{tabular}{|c|c|c|c|c|c|}
$\mathbf{x}$ & $\mathbf{l}_{\mathbf{x}}$ & $\mathbf{d}_{\mathbf{x}}$ & $\mathbf{p}_{\mathbf{x}}$ & $\mathbf{q}_{\mathbf{x}}$ & $\mathbf{e}_{\mathbf{x}}$ \\
\hline 36 & 97,299 & 96 & 0.99901 & 0.00099 & 39.26029 \\
\hline 37 & 97,203 & 106 & 0.99891 & 0.00109 & 38.29906 \\
\hline 38 & 97,097 & 117 & 0.99880 & 0.0012 & 37.34088 \\
\hline 39 & 96,980 & 131 & 0.99865 & 0.00135 & 36.38592 \\
\hline 40 & 96,849 & 148 & 0.99847 & 0.00153 & 35.43514 \\
\hline 41 & 96,701 & 169 & 0.99825 & 0.00175 & 34.48937 \\
\hline 42 & 96,532 & 189 & 0.99804 & 0.00196 & 33.54976 \\
\hline 43 & 96,343 & 211 & 0.99781 & 0.00219 & 32.61557 \\
\hline 44 & 96,132 & 236 & 0.99754 & 0.00246 & 31.68716 \\
\hline 45 & 95,896 & 268 & 0.99721 & 0.00279 & 30.76514 \\
\hline 46 & 95,628 & 304 & 0.99682 & 0.00318 & 29.85136 \\
\hline 47 & 95,324 & 346 & 0.99637 & 0.00363 & 28.94656 \\
\hline 48 & 94,978 & 393 & 0.99586 & 0.00414 & 28.05201 \\
\hline 49 & 94,585 & 445 & 0.99529 & 0.00471 & 27.16857 \\
\hline 50 & 94,140 & 506 & 0.99462 & 0.00538 & 26.29699 \\
\hline 51 & 93,634 & 576 & 0.99385 & 0.00615 & 25.43910 \\
\hline 52 & 93,058 & 650 & 0.99301 & 0.00699 & 24.59656 \\
\hline 53 & 92,408 & 724 & 0.99216 & 0.00784 & 23.76958 \\
\hline 54 & 91,684 & 799 & 0.99128 & 0.00872 & 22.95728 \\
\hline 55 & 90,885 & 873 & 0.99039 & 0.00961 & 22.15910 \\
\hline 56 & 90,012 & 946 & 0.98949 & 0.01051 & 21.37402 \\
\hline 57 & 89,066 & 1017 & 0.98858 & 0.01142 & 20.60104 \\
\hline 58 & 88,049 & 1085 & 0.98768 & 0.01232 & 19.83899 \\
\hline 59 & 86,964 & 1150 & 0.98678 & 0.01322 & 19.08651 \\
\hline 60 & 85,814 & 1216 & 0.98583 & 0.01417 & 18.34229 \\
\hline 61 & 84,598 & 1287 & 0.98479 & 0.01521 & 17.60594 \\
\hline 62 & 83,311 & 1365 & 0.98361 & 0.01639 & 16.87792 \\
\hline 63 & 81,946 & 1453 & 0.98227 & 0.01773 & 16.15906 \\
\hline 64 & 80,493 & 1550 & 0.98074 & 0.01926 & 15.45075 \\
\hline 65 & 78,943 & 1658 & 0.97900 & 0.021 & 14.75411 \\
\hline 66 & 77,285 & 1768 & 0.97712 & 0.02288 & 14.07063 \\
\hline 67 & 75,517 & 1877 & 0.97514 & 0.02486 & 13.40006 \\
\hline 68 & 73,640 & 1990 & 0.97298 & 0.02702 & 12.74161 \\
\hline 69 & 71,650 & 2093 & 0.97079 & 0.02921 & 12.09549 \\
\hline 70 & 69,557 & 2213 & 0.96818 & 0.03182 & 11.45945 \\
\hline 71 & 67,344 & 2339 & 0.96527 & 0.03473 & 10.83602 \\
\hline 72 & 65,005 & 2510 & 0.96139 & 0.03861 & 10.22592 \\
\hline 73 & 62,495 & 2665 & 0.95736 & 0.04264 & 9.63663 \\
\hline 74 & 59,830 & 2804 & 0.95313 & 0.04687 & 9.06587 \\
\hline 75 & 57,026 & 2940 & 0.94845 & 0.05155 & 8.51164 \\
\hline
\end{tabular}




\section{Pengantar Matematika Aktuaria 2018}

\begin{tabular}{|c|c|c|c|c|c|}
\hline $\mathbf{x}$ & $I_{x}$ & $d_{x}$ & $\mathbf{p}_{\mathrm{x}}$ & $\mathbf{q}_{\mathrm{x}}$ & $\mathbf{e}_{\mathrm{x}}$ \\
\hline 76 & 54,086 & 3063 & 0.94336 & 0.05664 & 7.97432 \\
\hline 77 & 51,023 & 3191 & 0.93746 & 0.06254 & 7.45303 \\
\hline 78 & 47,832 & 3320 & 0.93058 & 0.06942 & 6.95024 \\
\hline 79 & 44,512 & 3443 & 0.92266 & 0.07734 & 6.46864 \\
\hline 80 & 41,069 & 3531 & 0.91403 & 0.08597 & 6.01093 \\
\hline 81 & 37,538 & 3595 & 0.90423 & 0.09577 & 5.57635 \\
\hline 82 & 33,943 & 3596 & 0.89407 & 0.10593 & 5.16696 \\
\hline 83 & 30,347 & 3545 & 0.88317 & 0.11683 & 4.77922 \\
\hline 84 & 26,802 & 3454 & 0.87112 & 0.12888 & 4.41135 \\
\hline 85 & 23,348 & 3325 & 0.85759 & 0.14241 & 4.06395 \\
\hline 86 & 20,023 & 3151 & 0.84262 & 0.15738 & 3.73880 \\
\hline 87 & 16,872 & 2929 & 0.82637 & 0.17363 & 3.43706 \\
\hline 88 & 13,943 & 2665 & 0.80890 & 0.1911 & 3.15908 \\
\hline 89 & 11,278 & 2362 & 0.79055 & 0.20945 & 2.90557 \\
\hline 90 & 8,916 & 2038 & 0.77147 & 0.22853 & 2.67530 \\
\hline 91 & 6,878 & 1695 & 0.75362 & 0.24638 & 2.46801 \\
\hline 92 & 5,183 & 1373 & 0.73504 & 0.26496 & 2.27513 \\
\hline 93 & 3,810 & 1084 & 0.71550 & 0.2845 & 2.09501 \\
\hline 94 & 2,726 & 832 & 0.69489 & 0.30511 & 1.92810 \\
\hline 95 & 1,894 & 619 & 0.67318 & 0.32682 & 1.77508 \\
\hline 96 & 1,275 & 442 & 0.65338 & 0.34662 & 1.63686 \\
\hline 97 & 833 & 306 & 0.63230 & 0.3677 & 1.50540 \\
\hline 98 & 527 & 206 & 0.60984 & 0.39016 & 1.37951 \\
\hline 99 & 321 & 133 & 0.58587 & 0.41413 & 1.26480 \\
\hline 100 & 188 & 83 & 0.56026 & 0.43974 & 1.15957 \\
\hline 101 & 105 & 48 & 0.54006 & 0.45994 & 1.07619 \\
\hline 102 & 57 & 27 & 0.51857 & 0.48143 & 0.98246 \\
\hline 103 & 30 & 15 & 0.49569 & 0.50431 & 0.86667 \\
\hline 104 & 15 & 8 & 0.47136 & 0.52864 & 0.73333 \\
\hline 105 & 7 & 4 & 0.44550 & 0.5545 & 0.57143 \\
\hline 106 & 3 & 2 & 0.41802 & 0.58198 & 0.33333 \\
\hline 107 & 1 & 1 & - & 1 & - \\
\hline
\end{tabular}




\section{\begin{tabular}{l|l} 
Pengantar Matematika Aktuaria & 2018
\end{tabular}}

LAMPIRAN II. TABEL MORTALITAS INDONESIA 2011 (PEREMPUAN)

\begin{tabular}{|c|c|c|c|c|c|}
\hline $\mathbf{x}$ & $\mathbf{l}_{\mathbf{x}}$ & $\mathbf{d}_{\mathbf{x}}$ & $\mathbf{p}_{\mathbf{x}}$ & $\mathbf{q}_{\mathbf{x}}$ & $\mathbf{e}_{\mathbf{x}}$ \\
\hline 0 & 100,000 & 370 & 0.99630 & 0.0037 & 78.72405 \\
\hline 1 & 99,630 & 56 & 0.99944 & 0.00056 & 78.01641 \\
\hline 2 & 99,574 & 42 & 0.99958 & 0.00042 & 77.06029 \\
\hline 3 & 99,532 & 33 & 0.99967 & 0.00033 & 76.09280 \\
\hline 4 & 99,499 & 28 & 0.99972 & 0.00028 & 75.11804 \\
\hline 5 & 99,471 & 27 & 0.99973 & 0.00027 & 74.13919 \\
\hline 6 & 99,444 & 30 & 0.99970 & 0.0003 & 73.15932 \\
\hline 7 & 99,414 & 31 & 0.99969 & 0.00031 & 72.18139 \\
\hline 8 & 99,383 & 30 & 0.99970 & 0.0003 & 71.20391 \\
\hline 9 & 99,353 & 28 & 0.99972 & 0.00028 & 70.22541 \\
\hline 10 & 99,325 & 25 & 0.99975 & 0.00025 & 69.24521 \\
\hline 11 & 99,300 & 24 & 0.99976 & 0.00024 & 68.26264 \\
\hline 12 & 99,276 & 26 & 0.99974 & 0.00026 & 67.27914 \\
\hline 13 & 99,250 & 28 & 0.99972 & 0.00028 & 66.29677 \\
\hline 14 & 99,222 & 29 & 0.99971 & 0.00029 & 65.31547 \\
\hline 15 & 99,193 & 28 & 0.99972 & 0.00028 & 64.33457 \\
\hline 16 & 99,165 & 25 & 0.99975 & 0.00025 & 63.35274 \\
\hline 17 & 99,140 & 24 & 0.99976 & 0.00024 & 62.36871 \\
\hline 18 & 99,116 & 23 & 0.99977 & 0.00023 & 61.38381 \\
\hline 19 & 99,093 & 24 & 0.99976 & 0.00024 & 60.39806 \\
\hline 20 & 99,069 & 26 & 0.99974 & 0.00026 & 59.41269 \\
\hline 21 & 99,043 & 29 & 0.99971 & 0.00029 & 58.42829 \\
\hline 22 & 99,014 & 33 & 0.99967 & 0.00033 & 57.44540 \\
\hline 23 & 98,981 & 37 & 0.99963 & 0.00037 & 56.46455 \\
\hline 24 & 98,944 & 39 & 0.99961 & 0.00039 & 55.48567 \\
\hline 25 & 98,905 & 42 & 0.99958 & 0.00042 & 54.50755 \\
\hline 26 & 98,863 & 43 & 0.99956 & 0.00044 & 53.53070 \\
\hline 27 & 98,820 & 45 & 0.99954 & 0.00046 & 52.55400 \\
\hline 28 & 98,775 & 47 & 0.99952 & 0.00048 & 51.57794 \\
\hline 29 & 98,728 & 50 & 0.99949 & 0.00051 & 50.60249 \\
\hline 30 & 98,678 & 53 & 0.99946 & 0.00054 & 49.62813 \\
\hline 31 & 98,625 & 56 & 0.99943 & 0.00057 & 48.65480 \\
\hline 32 & 98,569 & 59 & 0.99940 & 0.0006 & 47.68245 \\
\hline 33 & 98,510 & 61 & 0.99938 & 0.00062 & 46.71100 \\
\hline 34 & 98,449 & 63 & 0.99936 & 0.00064 & 45.73995 \\
\hline 35 & 98,386 & 66 & 0.99933 & 0.00067 & 44.76924 \\
\hline & & & & & \\
\hline
\end{tabular}




\section{Pengantar Matematika Aktuaria 2018}

\begin{tabular}{|c|c|c|c|c|c|}
$\mathbf{x}$ & $\mathbf{l}_{\mathbf{x}}$ & $\mathbf{d}_{\mathbf{x}}$ & $\mathbf{p}_{\mathbf{x}}$ & $\mathbf{q}_{\mathbf{x}}$ & $\mathbf{e}_{\mathbf{x}}$ \\
\hline 36 & 98,320 & 73 & 0.99926 & 0.00074 & 43.79929 \\
\hline 37 & 98,247 & 83 & 0.99916 & 0.00084 & 42.83183 \\
\hline 38 & 98,164 & 91 & 0.99907 & 0.00093 & 41.86805 \\
\hline 39 & 98,073 & 102 & 0.99896 & 0.00104 & 40.90690 \\
\hline 40 & 97,971 & 112 & 0.99886 & 0.00114 & 39.94949 \\
\hline 41 & 97,859 & 123 & 0.99874 & 0.00126 & 38.99521 \\
\hline 42 & 97,736 & 138 & 0.99859 & 0.00141 & 38.04428 \\
\hline 43 & 97,598 & 154 & 0.99842 & 0.00158 & 37.09808 \\
\hline 44 & 97,444 & 171 & 0.99825 & 0.00175 & 36.15671 \\
\hline 45 & 97,273 & 188 & 0.99807 & 0.00193 & 35.22027 \\
\hline 46 & 97,085 & 208 & 0.99786 & 0.00214 & 34.28847 \\
\hline 47 & 96,877 & 232 & 0.99761 & 0.00239 & 33.36209 \\
\hline 48 & 96,645 & 259 & 0.99732 & 0.00268 & 32.44217 \\
\hline 49 & 96,386 & 288 & 0.99701 & 0.00299 & 31.52935 \\
\hline 50 & 96,098 & 321 & 0.99666 & 0.00334 & 30.62384 \\
\hline 51 & 95,777 & 358 & 0.99626 & 0.00374 & 29.72648 \\
\hline 52 & 95,419 & 403 & 0.99578 & 0.00422 & 28.83801 \\
\hline 53 & 95,016 & 455 & 0.99521 & 0.00479 & 27.96032 \\
\hline 54 & 94,561 & 513 & 0.99458 & 0.00542 & 27.09486 \\
\hline 55 & 94,048 & 571 & 0.99393 & 0.00607 & 26.24265 \\
\hline 56 & 93,477 & 625 & 0.99331 & 0.00669 & 25.40295 \\
\hline 57 & 92,852 & 673 & 0.99275 & 0.00725 & 24.57395 \\
\hline 58 & 92,179 & 715 & 0.99224 & 0.00776 & 23.75336 \\
\hline 59 & 91,464 & 755 & 0.99174 & 0.00826 & 22.93905 \\
\hline 60 & 90,709 & 796 & 0.99123 & 0.00877 & 22.12998 \\
\hline 61 & 89,913 & 842 & 0.99064 & 0.00936 & 21.32589 \\
\hline 62 & 89,071 & 894 & 0.98996 & 0.01004 & 20.52749 \\
\hline 63 & 88,177 & 973 & 0.98896 & 0.01104 & 19.73561 \\
\hline 64 & 87,204 & 1059 & 0.98786 & 0.01214 & 18.95582 \\
\hline 65 & 86,145 & 1149 & 0.98666 & 0.01334 & 18.18884 \\
\hline 66 & 84,996 & 1246 & 0.98534 & 0.01466 & 17.43473 \\
\hline 67 & 83,750 & 1350 & 0.98388 & 0.01612 & 16.69411 \\
\hline 68 & 82,400 & 1459 & 0.98229 & 0.01771 & 15.96762 \\
\hline 69 & 80,941 & 1576 & 0.98053 & 0.01947 & 15.25545 \\
\hline 70 & 79,365 & 1683 & 0.97879 & 0.02121 & 14.55838 \\
\hline 71 & 77,682 & 1801 & 0.97681 & 0.02319 & 13.87379 \\
\hline 72 & 75,881 & 1927 & 0.97461 & 0.02539 & 13.20308 \\
\hline 73 & 73,954 & 2054 & 0.97222 & 0.02778 & 12.54711 \\
\hline 74 & 71,900 & 2187 & 0.96958 & 0.03042 & 11.90555 \\
\hline 75 & 69,713 & 2321 & 0.96670 & 0.0333 & 11.27904 \\
\hline
\end{tabular}




\section{Pengantar Matematika Aktuaria 2018}

\begin{tabular}{|c|c|c|c|c|c|}
$\mathbf{x}$ & $\mathbf{l}_{\mathbf{x}}$ & $\mathbf{d}_{\mathbf{x}}$ & $\mathbf{p}_{\mathbf{x}}$ & $\mathbf{q}_{\mathbf{x}}$ & $\mathbf{e}_{\mathbf{x}}$ \\
\hline 76 & 67,392 & 2457 & 0.96354 & 0.03646 & 10.66750 \\
\hline 77 & 64,935 & 2592 & 0.96009 & 0.03991 & 10.07113 \\
\hline 78 & 62,343 & 2726 & 0.95628 & 0.04372 & 9.48985 \\
\hline 79 & 59,617 & 2855 & 0.95211 & 0.04789 & 8.92378 \\
\hline 80 & 56,762 & 2978 & 0.94753 & 0.05247 & 8.37263 \\
\hline 81 & 53,784 & 3161 & 0.94123 & 0.05877 & 7.83622 \\
\hline 82 & 50,623 & 3330 & 0.93421 & 0.06579 & 7.32552 \\
\hline 83 & 47,293 & 3445 & 0.92716 & 0.07284 & 6.84133 \\
\hline 84 & 43,848 & 3535 & 0.91939 & 0.08061 & 6.37883 \\
\hline 85 & 40,313 & 3598 & 0.91075 & 0.08925 & 5.93818 \\
\hline 86 & 36,715 & 3566 & 0.90287 & 0.09713 & 5.52011 \\
\hline 87 & 33,149 & 3611 & 0.89107 & 0.10893 & 5.11394 \\
\hline 88 & 29,538 & 3583 & 0.87869 & 0.12131 & 4.73912 \\
\hline 89 & 25,955 & 3491 & 0.86550 & 0.1345 & 4.39333 \\
\hline 90 & 22,464 & 3290 & 0.85355 & 0.14645 & 4.07608 \\
\hline 91 & 19,174 & 2923 & 0.84757 & 0.15243 & 3.77548 \\
\hline 92 & 16,251 & 2674 & 0.83546 & 0.16454 & 3.45456 \\
\hline 93 & 13,577 & 2476 & 0.81765 & 0.18235 & 3.13493 \\
\hline 94 & 11,101 & 2274 & 0.79512 & 0.20488 & 2.83416 \\
\hline 95 & 8,827 & 2057 & 0.76695 & 0.23305 & 2.56429 \\
\hline 96 & 6,770 & 1758 & 0.74038 & 0.25962 & 2.34343 \\
\hline 97 & 5,012 & 1439 & 0.71280 & 0.2872 & 2.16540 \\
\hline 98 & 3,573 & 1042 & 0.70827 & 0.29173 & 2.03750 \\
\hline 99 & 2,531 & 779 & 0.69241 & 0.30759 & 1.87633 \\
\hline 100 & 1,752 & 582 & 0.66759 & 0.33241 & 1.71062 \\
\hline 101 & 1,170 & 420 & 0.64082 & 0.35918 & 1.56154 \\
\hline 102 & 750 & 292 & 0.61129 & 0.38871 & 1.43600 \\
\hline 103 & 458 & 193 & 0.57876 & 0.42124 & 1.35153 \\
\hline 104 & 265 & 78 & 0.54295 & 0.45705 & 1.33585 \\
\hline 105 & 187 & 93 & 0.50420 & 0.4958 & 0.89305 \\
\hline 106 & 94 & 50 & 0.46447 & 0.53553 & 0.77660 \\
\hline 107 & 44 & 25 & 0.42374 & 0.57626 & 0.65909 \\
\hline 108 & 19 & 12 & 0.38275 & 0.61725 & 0.52632 \\
\hline 109 & 7 & 5 & 0.34004 & 0.65996 & 0.42857 \\
\hline 110 & 2 & 1 & 0.29634 & 0.70366 & 0.50000 \\
\hline 111 & 1 & 1 & - & 1 & - \\
\hline & & & & & \\
\hline 854 &
\end{tabular}




\title{
\begin{tabular}{l|l} 
Pengantar Matematika Aktuaria & 2018
\end{tabular}
}

\author{
LAMPIRAN III. TABEL KOMUTASI 5\% (LAKI-LAKI)
}

\begin{tabular}{|c|c|c|c|c|c|c|}
\hline $\mathbf{x}$ & $\mathbf{I}_{\mathbf{x}}$ & $\mathbf{d}_{\mathbf{x}}$ & $\mathbf{D}_{\mathbf{x}}$ & $\mathbf{N}_{\mathbf{x}}$ & $\mathbf{C}_{\mathbf{x}}$ & $\mathbf{M}_{\mathbf{x}}$ \\
\hline 0 & 100,000 & 802 & $100,000.00$ & $2,008,172.54$ & 763.81 & $4,372.74$ \\
\hline 1 & 99,198 & 78 & $94,474.29$ & $1,908,172.54$ & 70.75 & $3,608.93$ \\
\hline 2 & 99,120 & 62 & $89,904.76$ & $1,813,698.25$ & 53.56 & $3,538.18$ \\
\hline 3 & 99,058 & 51 & $85,570.02$ & $1,723,793.49$ & 41.96 & $3,484.62$ \\
\hline 4 & 99,007 & 43 & $81,453.30$ & $1,638,223.46$ & 33.69 & $3,442.66$ \\
\hline 5 & 98,964 & 38 & $77,540.88$ & $1,556,770.16$ & 28.36 & $3,408.97$ \\
\hline 6 & 98,926 & 34 & $73,820.10$ & $1,479,229.28$ & 24.16 & $3,380.61$ \\
\hline 7 & 98,892 & 31 & $70,280.70$ & $1,405,409.17$ & 20.98 & $3,356.45$ \\
\hline 8 & 98,861 & 29 & $66,913.02$ & $1,335,128.47$ & 18.69 & $3,335.47$ \\
\hline 9 & 98,832 & 28 & $63,707.99$ & $1,268,215.46$ & 17.19 & $3,316.78$ \\
\hline 10 & 98,804 & 27 & $60,657.09$ & $1,204,507.47$ & 15.79 & $3,299.59$ \\
\hline 11 & 98,777 & 27 & $57,752.87$ & $1,143,850.38$ & 15.03 & $3,283.80$ \\
\hline 12 & 98,750 & 26 & $54,987.70$ & $1,086,097.52$ & 13.79 & $3,268.77$ \\
\hline 13 & 98,724 & 26 & $52,355.45$ & $1,031,109.82$ & 13.13 & $3,254.98$ \\
\hline 14 & 98,698 & 27 & $49,849.20$ & $978,754.38$ & 12.99 & $3,241.85$ \\
\hline 15 & 98,671 & 29 & $47,462.44$ & $928,905.18$ & 13.29 & $3,228.86$ \\
\hline 16 & 98,642 & 30 & $45,189.04$ & $881,442.74$ & 13.09 & $3,215.57$ \\
\hline 17 & 98,612 & 32 & $43,024.09$ & $836,253.71$ & 13.30 & $3,202.48$ \\
\hline 18 & 98,580 & 35 & $40,962.03$ & $793,229.62$ & 13.85 & $3,189.19$ \\
\hline 19 & 98,545 & 40 & $38,997.60$ & $752,267.59$ & 15.08 & $3,175.34$ \\
\hline 20 & 98,505 & 48 & $37,125.50$ & $713,269.99$ & 17.23 & $3,160.26$ \\
\hline 21 & 98,457 & 58 & $35,340.39$ & $676,144.49$ & 19.83 & $3,143.03$ \\
\hline 22 & 98,399 & 68 & $33,637.69$ & $640,804.10$ & 22.14 & $3,123.20$ \\
\hline 23 & 98,331 & 76 & $32,013.75$ & $607,166.42$ & 23.57 & $3,101.07$ \\
\hline 24 & 98,255 & 82 & $30,465.72$ & $575,152.66$ & 24.21 & $3,077.50$ \\
\hline 25 & 98,173 & 83 & $28,990.76$ & $544,686.94$ & 23.34 & $3,053.29$ \\
\hline 26 & 98,090 & 81 & $27,586.90$ & $515,696.18$ & 21.70 & $3,029.94$ \\
\hline 27 & 98,009 & 77 & $26,251.55$ & $488,109.28$ & 19.64 & $3,008.25$ \\
\hline 28 & 97,932 & 73 & $24,981.83$ & $461,857.73$ & 17.74 & $2,988.60$ \\
\hline 29 & 97,859 & 72 & $23,774.48$ & $436,875.90$ & 16.66 & $2,970.87$ \\
\hline 30 & 97,787 & 74 & $22,625.71$ & $413,101.42$ & 16.31 & $2,954.21$ \\
\hline 31 & 97,713 & 78 & $21,531.99$ & $390,475.71$ & 16.37 & $2,937.90$ \\
\hline 32 & 97,635 & 81 & $20,490.28$ & $368,943.73$ & 16.19 & $2,921.53$ \\
\hline 33 & 97,554 & 82 & $19,498.37$ & $348,453.44$ & 15.61 & $2,905.34$ \\
\hline 34 & 97,472 & 84 & $18,554.26$ & $328,955.08$ & 15.23 & $2,889.74$ \\
\hline 35 & 97,388 & 89 & $17,655.50$ & $310,400.82$ & 15.37 & $2,874.51$ \\
\hline
\end{tabular}




\section{Pengantar Matematika Aktuaria 2018}

\begin{tabular}{|c|c|c|c|c|c|c|}
\hline$\underline{\mathbf{x}}$ & $l_{x}$ & $d_{x}$ & $\mathbf{D}_{\mathrm{x}}$ & $\mathbf{N}_{\mathbf{x}}$ & $C_{x}$ & $\mathbf{M}_{\mathbf{x}}$ \\
\hline 36 & 97,299 & 96 & $16,799.39$ & $292,745.32$ & 15.79 & $2,859.14$ \\
\hline 37 & 7,203 & 106 & $15,983.64$ & $275,945.92$ & 16.60 & $2,843.35$ \\
\hline 38 & 97,097 & 117 & $15,205.91$ & $259,962.29$ & 17.45 & $2,826.75$ \\
\hline 39 & 96,980 & 131 & $14,464.37$ & $244,756.38$ & 18.61 & $2,809.30$ \\
\hline 40 & 96,849 & 148 & $13,756.98$ & $230,292.01$ & 20.02 & $2,790.70$ \\
\hline 41 & 96,701 & 169 & $13,081.87$ & $216,535.02$ & 21.77 & $2,770.67$ \\
\hline 42 & 96,532 & 189 & $12,437.15$ & $203,453.16$ & 23.19 & $2,748.90$ \\
\hline 43 & 96,343 & 211 & $11,821.71$ & $191,016.01$ & 24.66 & $2,725.71$ \\
\hline 44 & 96,132 & 236 & 34.11 & $179,194.30$ & 26.27 & $2,701.05$ \\
\hline 45 & 95,896 & 268 & $10,672.89$ & $167,960.19$ & 28.41 & $2,674.79$ \\
\hline 46 & 95,628 & 304 & 25 & 287.30 & 30.69 & $2,646.38$ \\
\hline 47 & 95,324 & 346 & 38 & 05 & 33.27 & .69 \\
\hline 48 & 94,978 & 393 & $9,131.39$ & $137,528.16$ & 35.98 & $2,582.43$ \\
\hline 49 & 94,585 & 445 & & 78 & 38.81 & 546.44 \\
\hline 50 & 94,140 & 506 & & $11 c$ & 42.02 & 07.63 \\
\hline 51 & 93,634 & 576 & $7,776.41$ & $111,526.85$ & 45.56 & $2,465.61$ \\
\hline 52 & 93,058 & 650 & & $103,750.43$ & 48.96 & 420.05 \\
\hline 53 & 92,408 & 724 & & 96 & 51.94 & $2,371.09$ \\
\hline 54 & 91,684 & 799 & $6,577.66$ & 80 & 54.59 & $2,319.15$ \\
\hline 55 & 90,885 & 873 & & & 56.81 & 4.55 \\
\hline 56 & 90,012 & 946 & & & 58.63 & $2,207.74$ \\
\hline 57 & 89,066 & 1017 & 78 & 97 & 60.03 & $2,149.12$ \\
\hline 58 & 88, & & & & & .09 \\
\hline 59 & 86,964 & 1150 & & 28 & 61.57 & $2,028.10$ \\
\hline 60 & 85,814 & 1216 & $4,594.10$ & 83 & 62.00 & 966.53 \\
\hline 61 & 84,598 & 1287 & & 74 & 62.49 & $1,904.53$ \\
\hline 62 & 83,311 & 1365 & & & 63.13 & $1,842.04$ \\
\hline 63 & 81,946 & 1453 & $3,789.67$ & 42,22 & 64.00 & $1,778.91$ \\
\hline 64 & 80,493 & 1550 & & & 65.02 & $1,714.92$ \\
\hline 65 & 78,943 & 1658 & 1.38 & $34,891.07$ & 66.24 & $1,649.90$ \\
\hline 66 & 77,285 & 1768 & $3,087.46$ & $31,579.69$ & 67.27 & $1,583.67$ \\
\hline 67 & 75,517 & 1877 & & $28,4 \mathrm{C}$ & 68.01 & $1,516.40$ \\
\hline 68 & 73,640 & 1990 & $2,668.34$ & $25,619.06$ & 68.67 & $1,448.39$ \\
\hline 69 & 71,650 & 2093 & $2,472.60$ & $22,950.71$ & 68.79 & $1,379.71$ \\
\hline 70 & 69,557 & 2213 & $2,286.07$ & $20,478.11$ & 69.27 & $1,310.92$ \\
\hline 71 & 67,344 & 2339 & $2,107.94$ & $18,192.04$ & 69.73 & $1,241.65$ \\
\hline 72 & 65,005 & 2510 & $1,937.84$ & $16,084.10$ & 71.26 & $1,171.93$ \\
\hline 73 & 62,495 & 2665 & $1,774.30$ & $14,146.26$ & 72.06 & $1,100.67$ \\
\hline 74 & 59,830 & 2804 & $1,617.75$ & $12,371.96$ & 72.21 & $1,028.61$ \\
\hline 75 & 57,026 & 2940 & $1,468.51$ & $10,754.21$ & 72.10 & 956.40 \\
\hline
\end{tabular}




\section{\begin{tabular}{l|l} 
Pengantar Matematika Aktuaria & 2018
\end{tabular}}

\begin{tabular}{|c|c|c|c|c|c|c|}
$\mathbf{x}$ & $\mathbf{l}_{\mathbf{x}}$ & $\mathbf{d}_{\mathbf{x}}$ & $\mathbf{D}_{\mathbf{x}}$ & $\mathbf{N}_{\mathbf{x}}$ & $\mathbf{C}_{\mathbf{x}}$ & $\mathbf{M}_{\mathbf{x}}$ \\
\hline 76 & 54,086 & 3063 & $1,326.47$ & $9,285.71$ & 71.54 & 884.30 \\
\hline 77 & 51,023 & 3191 & $1,191.76$ & $7,959.24$ & 70.98 & 812.75 \\
\hline 78 & 47,832 & 3320 & $1,064.03$ & $6,767.47$ & 70.34 & 741.77 \\
\hline 79 & 44,512 & 3443 & 943.02 & $5,703.45$ & 69.47 & 671.43 \\
\hline 80 & 41,069 & 3531 & 828.65 & $4,760.42$ & 67.85 & 601.96 \\
\hline 81 & 37,538 & 3595 & 721.34 & $3,931.77$ & 65.79 & 534.11 \\
\hline 82 & 33,943 & 3596 & 621.19 & $3,210.44$ & 62.68 & 468.32 \\
\hline 83 & 30,347 & 3545 & 528.94 & $2,589.24$ & 58.85 & 405.64 \\
\hline 84 & 26,802 & 3454 & 444.90 & $2,060.31$ & 54.60 & 346.79 \\
\hline 85 & 23,348 & 3325 & 369.11 & $1,615.40$ & 50.06 & 292.19 \\
\hline 86 & 20,023 & 3151 & 301.47 & $1,246.29$ & 45.18 & 242.13 \\
\hline 87 & 16,872 & 2929 & 241.93 & 944.82 & 40.00 & 196.94 \\
\hline 88 & 13,943 & 2665 & 190.41 & 702.88 & 34.66 & 156.94 \\
\hline 89 & 11,278 & 2362 & 146.68 & 512.47 & 29.26 & 122.28 \\
\hline 90 & 8,916 & 2038 & 110.44 & 365.78 & 24.04 & 93.02 \\
\hline 91 & 6,878 & 1695 & 81.14 & 255.34 & 19.04 & 68.98 \\
\hline 92 & 5,183 & 1373 & 58.23 & 174.20 & 14.69 & 49.94 \\
\hline 93 & 3,810 & 1084 & 40.77 & 115.97 & 11.05 & 35.25 \\
\hline 94 & 2,726 & 832 & 27.78 & 75.20 & 8.07 & 24.20 \\
\hline 95 & 1,894 & 619 & 18.38 & 47.42 & 5.72 & 16.12 \\
\hline 96 & 1,275 & 442 & 11.79 & 29.04 & 3.89 & 10.40 \\
\hline 97 & 833 & 306 & 7.33 & 17.25 & 2.57 & 6.51 \\
\hline 98 & 527 & 206 & 4.42 & 9.92 & 1.64 & 3.95 \\
\hline 99 & 321 & 133 & 2.56 & 5.50 & 1.01 & 2.30 \\
\hline 100 & 188 & 83 & 1.43 & 2.94 & 0.60 & 1.29 \\
\hline 101 & 105 & 48 & 0.76 & 1.51 & 0.33 & 0.69 \\
\hline 102 & 57 & 27 & 0.39 & 0.75 & 0.18 & 0.36 \\
\hline 103 & 30 & 15 & 0.20 & 0.36 & 0.09 & 0.18 \\
\hline 104 & 15 & 8 & 0.09 & 0.16 & 0.05 & 0.09 \\
\hline 105 & 7 & 4 & 0.04 & 0.06 & 0.02 & 0.04 \\
\hline 106 & 3 & 2 & 0.02 & 0.02 & 0.01 & 0.02 \\
\hline 107 & 1 & 1 & 0.01 & 0.01 & 0.01 & 0.01 \\
\hline & & & & & & \\
\hline
\end{tabular}




\title{
\begin{tabular}{l|l} 
Pengantar Matematika Aktuaria & 2018
\end{tabular}
}

\author{
LAMPIRAN IV. TABEL KOMUTASI 6\% (LAKI-LAKI)
}

\begin{tabular}{|c|c|c|c|c|c|c|}
\hline $\mathbf{x}$ & $\mathbf{l}_{\mathbf{x}}$ & $\mathbf{d}_{\mathbf{x}}$ & $\mathbf{D}_{\mathbf{x}}$ & $\mathbf{N}_{\mathbf{x}}$ & $\mathbf{C}_{\mathbf{x}}$ & $\mathbf{M}_{\mathbf{x}}$ \\
\hline 0 & 100,000 & 802 & $100,000.00$ & $1,715,108.89$ & 756.60 & $2,918.36$ \\
\hline 1 & 99,198 & 78 & $93,583.02$ & $1,615,108.89$ & 69.42 & $2,161.76$ \\
\hline 2 & 99,120 & 62 & $88,216.45$ & $1,521,525.87$ & 52.06 & $2,092.34$ \\
\hline 3 & 99,058 & 51 & $83,171.01$ & $1,433,309.43$ & 40.40 & $2,040.28$ \\
\hline 4 & 99,007 & 43 & $78,422.82$ & $1,350,138.42$ & 32.13 & $1,999.89$ \\
\hline 5 & 98,964 & 38 & $73,951.66$ & $1,271,715.60$ & 26.79 & $1,967.76$ \\
\hline 6 & 98,926 & 34 & $69,738.93$ & $1,197,763.94$ & 22.61 & $1,940.97$ \\
\hline 7 & 98,892 & 31 & $65,768.83$ & $1,128,025.02$ & 19.45 & $1,918.36$ \\
\hline 8 & 98,861 & 29 & $62,026.61$ & $1,062,256.19$ & 17.17 & $1,898.91$ \\
\hline 9 & 98,832 & 28 & $58,498.51$ & $1,000,229.58$ & 15.64 & $1,881.74$ \\
\hline 10 & 98,804 & 27 & $55,171.64$ & $941,731.07$ & 14.22 & $1,866.11$ \\
\hline 11 & 98,777 & 27 & $52,034.49$ & $886,559.43$ & 13.42 & $1,851.88$ \\
\hline 12 & 98,750 & 26 & $49,075.72$ & $834,524.94$ & 12.19 & $1,838.46$ \\
\hline 13 & 98,724 & 26 & $46,285.66$ & $785,449.21$ & 11.50 & $1,826.27$ \\
\hline 14 & 98,698 & 27 & $43,654.22$ & $739,163.55$ & 11.27 & $1,814.77$ \\
\hline 15 & 98,671 & 29 & $41,171.96$ & $695,509.33$ & 11.42 & $1,803.51$ \\
\hline 16 & 98,642 & 30 & $38,830.06$ & $654,337.37$ & 11.14 & $1,792.09$ \\
\hline 17 & 98,612 & 32 & $36,620.99$ & $615,507.31$ & 11.21 & $1,780.95$ \\
\hline 18 & 98,580 & 35 & $34,536.89$ & $578,886.32$ & 11.57 & $1,769.74$ \\
\hline 19 & 98,545 & 40 & $32,570.40$ & $544,349.43$ & 12.47 & $1,758.17$ \\
\hline 20 & 98,505 & 48 & $30,714.32$ & $511,779.03$ & 14.12 & $1,745.70$ \\
\hline 21 & 98,457 & 58 & $28,961.66$ & $481,064.70$ & 16.10 & $1,731.58$ \\
\hline 22 & 98,399 & 68 & $27,306.22$ & $452,103.04$ & 17.80 & $1,715.49$ \\
\hline 23 & 98,331 & 76 & $25,742.79$ & $424,796.82$ & 18.77 & $1,697.68$ \\
\hline 24 & 98,255 & 82 & $24,266.88$ & $399,054.03$ & 19.11 & $1,678.91$ \\
\hline 25 & 98,173 & 83 & $22,874.17$ & $374,787.16$ & 18.24 & $1,659.81$ \\
\hline 26 & 98,090 & 81 & $21,561.17$ & $351,912.98$ & 16.80 & $1,641.56$ \\
\hline 27 & 98,009 & 77 & $20,323.93$ & $330,351.82$ & 15.06 & $1,624.77$ \\
\hline 28 & 97,932 & 73 & $19,158.45$ & $310,027.89$ & 13.47 & $1,609.70$ \\
\hline 29 & 97,859 & 72 & $18,060.54$ & $290,869.44$ & 12.54 & $1,596.23$ \\
\hline 30 & 97,787 & 74 & $17,025.71$ & $272,808.90$ & 12.15 & $1,583.69$ \\
\hline 31 & 97,713 & 78 & $16,049.83$ & $255,783.19$ & 12.09 & $1,571.54$ \\
\hline 32 & 97,635 & 81 & $15,129.27$ & $239,733.36$ & 11.84 & $1,559.45$ \\
\hline 33 & 97,554 & 82 & $14,261.05$ & $224,604.10$ & 11.31 & $1,547.61$ \\
\hline 34 & 97,472 & 84 & $13,442.51$ & $210,343.04$ & 10.93 & $1,536.30$ \\
\hline 35 & 97,388 & 89 & $12,670.69$ & $196,900.53$ & 10.92 & $1,525.37$ \\
\hline
\end{tabular}




\section{Pengantar Matematika Aktuaria 2018}

\begin{tabular}{|c|c|c|c|c|c|c|}
\hline $\mathbf{x}$ & $\mathbf{l}_{\mathrm{x}}$ & $\mathbf{d}_{\mathbf{x}}$ & $\mathbf{D}_{\mathbf{x}}$ & $\mathbf{N}_{\mathbf{x}}$ & $C_{x}$ & $\mathbf{M}_{\mathbf{x}}$ \\
\hline 36 & 97,299 & 96 & $11,942.55$ & $184,229.84$ & 11.12 & $1,514.45$ \\
\hline 37 & 97,203 & 106 & $11,255.44$ & $172,287.29$ & 11.58 & $1,503.33$ \\
\hline 38 & 97,097 & 117 & $10,606.76$ & $161,031.85$ & 12.06 & $1,491.75$ \\
\hline 39 & 96,980 & 131 & $9,994.32$ & $150,425.08$ & 12.74 & $1,479.70$ \\
\hline 40 & 96,849 & 148 & $9,415.87$ & $140,430.76$ & 13.57 & $1,466.96$ \\
\hline 41 & 96,701 & 169 & $8,869.32$ & $131,014.89$ & 14.62 & $1,453.39$ \\
\hline 42 & 96,532 & 189 & $8,352.66$ & $122,145.56$ & 15.43 & $1,438.76$ \\
\hline 43 & 96,343 & 211 & $7,864.44$ & $113,792.90$ & 16.25 & $1,423.34$ \\
\hline 44 & 96,132 & 236 & $7,403.04$ & $105,928.46$ & 17.15 & $1,407.09$ \\
\hline 45 & 95,896 & 268 & 6,96 & 5.42 & 37 & $1,389.94$ \\
\hline 46 & 95,628 & 304 & $6,554.13$ & 8.57 & 19.66 & $1,371.57$ \\
\hline 47 & 95,324 & 346 & $6,163.49$ & 4.43 & 21.11 & $1,351.92$ \\
\hline 48 & 94,978 & 393 & $5,793.51$ & $78,840.95$ & 22.62 & $1,330.81$ \\
\hline 49 & 94,585 & 445 & $5,442.96$ & $73,047.44$ & 24.16 & $1,308.20$ \\
\hline 50 & 94,140 & 506 & 0.71 & 67 & & $1,284.04$ \\
\hline 51 & 93,634 & 576 & $4,795.51$ & $62,493.78$ & 27.83 & $1,258.12$ \\
\hline 52 & 93,058 & 650 & $4,496.23$ & $57,698.27$ & 29.63 & $1,230.29$ \\
\hline 53 & 92,408 & 724 & & & & \\
\hline 54 & 91,684 & 799 & $3,942.55$ & 9.94 & 32.41 & $1,169.53$ \\
\hline 55 & 90,885 & 873 & $3,686.97$ & $45,047.39$ & 33.41 & $1,137.12$ \\
\hline 56 & 90,012 & 946 & $3,444.86$ & 42 & 34.16 & $1,103.71$ \\
\hline 57 & 89,066 & 1017 & $3,215.72$ & 5.56 & 34.64 & $1,069.55$ \\
\hline 58 & 88,049 & 1085 & $2,999.05$ & $34,699.84$ & 34.86 & $1,034.91$ \\
\hline 59 & 86,964 & 1150 & $2,794.43$ & $31,700.79$ & 34.86 & $1,000.05$ \\
\hline 60 & 85,814 & 1216 & $2,601.39$ & $28,906.36$ & 34.78 & 965.19 \\
\hline 61 & 84,598 & 1287 & $2,419.37$ & 4.96 & 34.72 & 30.41 \\
\hline 62 & 83,311 & 1365 & $2,247.70$ & & 34.74 & 895.69 \\
\hline 63 & 81,946 & 1453 & $2,085.73$ & $21,637.89$ & 34.89 & 860.94 \\
\hline 64 & 80,493 & 1550 & $1,932.78$ & .16 & 35.11 & 826.06 \\
\hline 65 & 78,943 & 1658 & $1,788.27$ & $17,619.38$ & 35.43 & 790.94 \\
\hline 66 & 77,285 & 1768 & $1,651.61$ & $15,831.11$ & 35.64 & 755.51 \\
\hline 67 & 75,517 & 1877 & $1,522.48$ & $14,179.50$ & 35.70 & 719.87 \\
\hline 68 & 73,640 & 1990 & $1,400.60$ & $12,657.02$ & 35.71 & 684.17 \\
\hline 69 & 71,650 & 2093 & $1,285.62$ & $11,256.42$ & 35.43 & 648.46 \\
\hline 70 & 69,557 & 2213 & $1,177.42$ & $9,970.80$ & 35.34 & 613.03 \\
\hline 71 & 67,344 & 2339 & $1,075.43$ & $8,793.38$ & 35.24 & 577.69 \\
\hline 72 & 65,005 & 2510 & 979.32 & $7,717.95$ & 35.67 & 542.45 \\
\hline 73 & 62,495 & 2665 & 888.21 & $6,738.63$ & 35.73 & 506.78 \\
\hline 74 & 59,830 & 2804 & 802.20 & $5,850.42$ & 35.47 & 471.05 \\
\hline 75 & 57,026 & 2940 & 721.33 & $5,048.22$ & 35.08 & 435.58 \\
\hline
\end{tabular}




\section{\begin{tabular}{l|l} 
Pengantar Matematika Aktuaria & 2018
\end{tabular}}

\begin{tabular}{|c|c|c|c|c|c|c|}
$\mathbf{x}$ & $\mathbf{l}_{\mathbf{x}}$ & $\mathbf{d}_{\mathbf{x}}$ & $\mathbf{D}_{\mathbf{x}}$ & $\mathbf{N}_{\mathbf{x}}$ & $\mathbf{C}_{\mathbf{x}}$ & $\mathbf{M}_{\mathbf{x}}$ \\
\hline 76 & 54,086 & 3063 & 645.42 & $4,326.89$ & 34.48 & 400.50 \\
\hline 77 & 51,023 & 3191 & 574.40 & $3,681.47$ & 33.89 & 366.01 \\
\hline 78 & 47,832 & 3320 & 508.00 & $3,107.07$ & 33.26 & 332.12 \\
\hline 79 & 44,512 & 3443 & 445.98 & $2,599.07$ & 32.54 & 298.86 \\
\hline 80 & 41,069 & 3531 & 388.19 & $2,153.10$ & 31.49 & 266.32 \\
\hline 81 & 37,538 & 3595 & 334.73 & $1,764.91$ & 30.24 & 234.83 \\
\hline 82 & 33,943 & 3596 & 285.54 & $1,430.18$ & 28.54 & 204.59 \\
\hline 83 & 30,347 & 3545 & 240.84 & $1,144.63$ & 26.54 & 176.05 \\
\hline 84 & 26,802 & 3454 & 200.67 & 903.79 & 24.40 & 149.51 \\
\hline 85 & 23,348 & 3325 & 164.91 & 703.13 & 22.16 & 125.11 \\
\hline 86 & 20,023 & 3151 & 133.42 & 538.22 & 19.81 & 102.96 \\
\hline 87 & 16,872 & 2929 & 106.06 & 404.79 & 17.37 & 83.15 \\
\hline 88 & 13,943 & 2665 & 82.69 & 298.73 & 14.91 & 65.78 \\
\hline 89 & 11,278 & 2362 & 63.10 & 216.05 & 12.47 & 50.87 \\
\hline 90 & 8,916 & 2038 & 47.06 & 152.95 & 10.15 & 38.40 \\
\hline 91 & 6,878 & 1695 & 34.25 & 105.89 & 7.96 & 28.25 \\
\hline 92 & 5,183 & 1373 & 24.35 & 71.64 & 6.08 & 20.29 \\
\hline 93 & 3,810 & 1084 & 16.88 & 47.30 & 4.53 & 14.21 \\
\hline 94 & 2,726 & 832 & 11.40 & 30.41 & 3.28 & 9.68 \\
\hline 95 & 1,894 & 619 & 7.47 & 19.01 & 2.30 & 6.39 \\
\hline 96 & 1,275 & 442 & 4.74 & 11.54 & 1.55 & 4.09 \\
\hline 97 & 833 & 306 & 2.92 & 6.80 & 1.01 & 2.54 \\
\hline 98 & 527 & 206 & 1.75 & 3.88 & 0.64 & 1.53 \\
\hline 99 & 321 & 133 & 1.00 & 2.13 & 0.39 & 0.88 \\
\hline 100 & 188 & 83 & 0.55 & 1.13 & 0.23 & 0.49 \\
\hline 101 & 105 & 48 & 0.29 & 0.57 & 0.13 & 0.26 \\
\hline 102 & 57 & 27 & 0.15 & 0.28 & 0.07 & 0.13 \\
\hline 103 & 30 & 15 & 0.07 & 0.13 & 0.04 & 0.07 \\
\hline 104 & 15 & 8 & 0.04 & 0.06 & 0.02 & 0.03 \\
\hline 105 & 7 & 4 & 0.02 & 0.02 & 0.01 & 0.01 \\
\hline 106 & 3 & 2 & 0.01 & 0.01 & 0.00 & 0.01 \\
\hline 107 & 1 & 1 & 0.00 & 0.00 & 0.00 & 0.00 \\
\hline & & & & & & \\
\hline
\end{tabular}




\section{\begin{tabular}{l|l} 
Pengantar Matematika Aktuaria & 2018
\end{tabular}}

\section{LAMPIRAN V. TABEL KOMUTASI 5\% (PEREMPUAN)}

\begin{tabular}{|c|c|c|c|c|c|c|}
\hline $\mathbf{x}$ & $\mathbf{l}_{\mathbf{x}}$ & $\mathbf{d}_{\mathbf{x}}$ & $\mathbf{D}_{\mathbf{x}}$ & $\mathbf{N}_{\mathbf{x}}$ & $\mathbf{C}_{\mathbf{x}}$ & $\mathbf{M}_{\mathbf{x}}$ \\
\hline 0 & 100,000 & 370 & $100,000.00$ & $2,031,656.24$ & 352.38 & $3,254.46$ \\
\hline 1 & 99,630 & 56 & $94,885.71$ & $1,931,656.24$ & 50.79 & $2,902.08$ \\
\hline 2 & 99,574 & 42 & $90,316.55$ & $1,836,770.52$ & 36.28 & $2,851.29$ \\
\hline 3 & 99,532 & 33 & $85,979.48$ & $1,746,453.97$ & 27.15 & $2,815.01$ \\
\hline 4 & 99,499 & 28 & $81,858.07$ & $1,660,474.49$ & 21.94 & $2,787.86$ \\
\hline 5 & 99,471 & 27 & $77,938.13$ & $1,578,616.41$ & 20.15 & $2,765.92$ \\
\hline 6 & 99,444 & 30 & $74,206.64$ & $1,500,678.28$ & 21.32 & $2,745.77$ \\
\hline 7 & 99,414 & 31 & $70,651.67$ & $1,426,471.64$ & 20.98 & $2,724.45$ \\
\hline 8 & 99,383 & 30 & $67,266.33$ & $1,355,819.96$ & 19.34 & $2,703.47$ \\
\hline 9 & 99,353 & 28 & $64,043.83$ & $1,288,553.64$ & 17.19 & $2,684.13$ \\
\hline 10 & 99,325 & 25 & $60,976.93$ & $1,224,509.81$ & 14.62 & $2,666.94$ \\
\hline 11 & 99,300 & 24 & $58,058.65$ & $1,163,532.87$ & 13.36 & $2,652.33$ \\
\hline 12 & 99,276 & 26 & $55,280.59$ & $1,105,474.22$ & 13.79 & $2,638.96$ \\
\hline 13 & 99,250 & 28 & $52,634.39$ & $1,050,193.63$ & 14.14 & $2,625.17$ \\
\hline 14 & 99,222 & 29 & $50,113.85$ & $997,559.23$ & 13.95 & $2,611.03$ \\
\hline 15 & 99,193 & 28 & $47,713.53$ & $947,445.38$ & 12.83 & $2,597.08$ \\
\hline 16 & 99,165 & 25 & $45,428.63$ & $899,731.85$ & 10.91 & $2,584.26$ \\
\hline 17 & 99,140 & 24 & $43,254.45$ & $854,303.22$ & 9.97 & $2,573.35$ \\
\hline 18 & 99,116 & 23 & $41,184.75$ & $811,048.77$ & 9.10 & $2,563.38$ \\
\hline 19 & 99,093 & 24 & $39,214.47$ & $769,864.03$ & 9.05 & $2,554.27$ \\
\hline 20 & 99,069 & 26 & $37,338.06$ & $730,649.56$ & 9.33 & $2,545.23$ \\
\hline 21 & 99,043 & 29 & $35,550.73$ & $693,311.50$ & 9.91 & $2,535.90$ \\
\hline 22 & 99,014 & 33 & $33,847.92$ & $657,760.77$ & 10.74 & $2,525.98$ \\
\hline 23 & 98,981 & 37 & $32,225.37$ & $623,912.84$ & 11.47 & $2,515.24$ \\
\hline 24 & 98,944 & 39 & $30,679.36$ & $591,687.47$ & 11.52 & $2,503.77$ \\
\hline 25 & 98,905 & 42 & $29,206.92$ & $561,008.11$ & 11.81 & $2,492.25$ \\
\hline 26 & 98,863 & 43 & $27,804.30$ & $531,801.19$ & 11.52 & $2,480.44$ \\
\hline 27 & 98,820 & 45 & $26,468.77$ & $503,996.89$ & 11.48 & $2,468.92$ \\
\hline 28 & 98,775 & 47 & $25,196.87$ & $477,528.12$ & 11.42 & $2,457.44$ \\
\hline 29 & 98,728 & 50 & $23,985.60$ & $452,331.24$ & 11.57 & $2,446.02$ \\
\hline 30 & 98,678 & 53 & $22,831.86$ & $428,345.64$ & 11.68 & $2,434.45$ \\
\hline 31 & 98,625 & 56 & $21,732.95$ & $405,513.77$ & 11.75 & $2,422.77$ \\
\hline 32 & 98,569 & 59 & $20,686.30$ & $383,780.82$ & 11.79 & $2,411.02$ \\
\hline 33 & 98,510 & 61 & $19,689.44$ & $363,094.52$ & 11.61 & $2,399.23$ \\
\hline 34 & 98,449 & 63 & $18,740.24$ & $343,405.08$ & 11.42 & $2,387.62$ \\
\hline 35 & 98,386 & 66 & $17,836.43$ & $324,664.84$ & 11.40 & $2,376.20$ \\
\hline
\end{tabular}




\section{\begin{tabular}{l|l} 
Pengantar Matematika Aktuaria & 2018
\end{tabular}}

\begin{tabular}{|c|c|c|c|c|c|c|}
\hline $\mathbf{x}$ & $\mathbf{l}_{\mathrm{x}}$ & $d_{x}$ & $\mathbf{D}_{\mathrm{x}}$ & $\mathbf{N}_{\mathbf{x}}$ & $C_{x}$ & $\mathbf{M}_{\mathbf{x}}$ \\
\hline 36 & 98,320 & 73 & $16,975.68$ & $306,828.41$ & 12.00 & $2,364.80$ \\
\hline 37 & 98,247 & 83 & $16,155.31$ & $289,852.74$ & 13.00 & $2,352.80$ \\
\hline 38 & 98,164 & 91 & $15,373.01$ & $273,697.43$ & 13.57 & $2,339.80$ \\
\hline 39 & 98,073 & 102 & $14,627.39$ & $258,324.42$ & 14.49 & $2,326.23$ \\
\hline 40 & 97,971 & 112 & $13,916.36$ & $243,697.03$ & 15.15 & $2,311.74$ \\
\hline 41 & 97,859 & 123 & $13,238.52$ & $229,780.67$ & 15.85 & $2,296.59$ \\
\hline 42 & 97,736 & 138 & $12,592.27$ & $216,542.15$ & 16.93 & $2,280.74$ \\
\hline 43 & 97,598 & 154 & $11,975.70$ & $203,949.88$ & 18.00 & $2,263.80$ \\
\hline 44 & 97,444 & 171 & $11,387.44$ & $191,974.18$ & 19.03 & $2,245.81$ \\
\hline 45 & 97,273 & 188 & $10,826.15$ & $180,586.74$ & 19.93 & $2,226.78$ \\
\hline 46 & 97,085 & 208 & $10,290.69$ & $169,760.60$ & 21.00 & $2,206.85$ \\
\hline 47 & 96,877 & 232 & $9,779.66$ & $159,469.91$ & 22.30 & $2,185.85$ \\
\hline 48 & 96,645 & 259 & $9,291.65$ & $149,690.25$ & 23.72 & $2,163.55$ \\
\hline 49 & 96,386 & 288 & $8,825.48$ & $140,398.60$ & 25.11 & $2,139.83$ \\
\hline 50 & 96,098 & 321 & $8,380.10$ & $131,573.12$ & 26.66 & $2,114.72$ \\
\hline 51 & 95,777 & 358 & $7,954.39$ & $123,193.02$ & 28.32 & $2,088.06$ \\
\hline 52 & 95,419 & 403 & $7,547.29$ & $115,238.62$ & 30.36 & $2,059.74$ \\
\hline 53 & 95,016 & 455 & $7,157.54$ & $107,691.33$ & 32.64 & $2,029.38$ \\
\hline 54 & 94,561 & 513 & $6,784.06$ & $100,533.79$ & 35.05 & $1,996.74$ \\
\hline 55 & 94,048 & 571 & $6,425.96$ & $93,749.72$ & 37.16 & $1,961.69$ \\
\hline 56 & 93,477 & 625 & $6,082.81$ & $87,323.76$ & 38.73 & $1,924.53$ \\
\hline 57 & 92,852 & 673 & $5,754.42$ & $81,240.96$ & 39.72 & $1,885.80$ \\
\hline 58 & 92,179 & 715 & $5,440.67$ & $75,486.54$ & 40.19 & $1,846.08$ \\
\hline 59 & 91,464 & 755 & $5,141.40$ & $70,045.87$ & 40.42 & $1,805.88$ \\
\hline 60 & 90,709 & 796 & $4,856.15$ & $64,904.47$ & 40.59 & $1,765.46$ \\
\hline 61 & 89,913 & 842 & $4,584.32$ & $60,048.31$ & 40.89 & $1,724.88$ \\
\hline 62 & 89,071 & 894 & $4,325.14$ & $55,463.99$ & 41.34 & $1,683.99$ \\
\hline 63 & 88,177 & 973 & $4,077.83$ & $51,138.85$ & 42.85 & $1,642.65$ \\
\hline 64 & 87,204 & 1059 & $3,840.80$ & $47,061.02$ & 44.42 & $1,599.80$ \\
\hline 65 & 86,145 & 1149 & $3,613.48$ & $43,220.22$ & 45.90 & $1,555.37$ \\
\hline 66 & 84,996 & 1246 & $3,395.51$ & $39,606.74$ & 47.41 & $1,509.47$ \\
\hline 67 & 83,750 & 1350 & $3,186.41$ & $36,211.23$ & 48.92 & $1,462.07$ \\
\hline 68 & 82,400 & 1459 & $2,985.76$ & $33,024.82$ & 50.35 & $1,413.15$ \\
\hline 69 & 80,941 & 1576 & $2,793.23$ & $30,039.06$ & 51.80 & $1,362.80$ \\
\hline 70 & 79,365 & 1683 & $2,608.42$ & $27,245.83$ & 52.68 & $1,311.00$ \\
\hline 71 & 77,682 & 1801 & $2,431.53$ & $24,637.41$ & 53.69 & $1,258.32$ \\
\hline 72 & 75,881 & 1927 & $2,262.06$ & $22,205.88$ & 54.71 & $1,204.63$ \\
\hline 73 & 73,954 & 2054 & $2,099.63$ & $19,943.82$ & 55.54 & $1,149.92$ \\
\hline 74 & 71,900 & 2187 & $1,944.11$ & $17,844.19$ & 56.32 & $1,094.39$ \\
\hline 75 & 69,713 & 2321 & $1,795.21$ & $15,900.08$ & 56.92 & $1,038.07$ \\
\hline
\end{tabular}




\section{\begin{tabular}{l|l} 
Pengantar Matematika Aktuaria & 2018
\end{tabular}}

\begin{tabular}{|c|c|c|c|c|c|c|}
$\mathbf{x}$ & $\mathbf{l}_{\mathbf{x}}$ & $\mathbf{d}_{\mathbf{x}}$ & $\mathbf{D}_{\mathbf{x}}$ & $\mathbf{N}_{\mathbf{x}}$ & $\mathbf{C}_{\mathbf{x}}$ & $\mathbf{M}_{\mathbf{x}}$ \\
\hline 76 & 67,392 & 2457 & $1,652.80$ & $14,104.86$ & 57.39 & 981.14 \\
\hline 77 & 64,935 & 2592 & $1,516.71$ & $12,452.06$ & 57.66 & 923.76 \\
\hline 78 & 62,343 & 2726 & $1,386.83$ & $10,935.35$ & 57.75 & 866.10 \\
\hline 79 & 59,617 & 2855 & $1,263.04$ & $9,548.52$ & 57.61 & 808.34 \\
\hline 80 & 56,762 & 2978 & $1,145.29$ & $8,285.49$ & 57.23 & 750.74 \\
\hline 81 & 53,784 & 3161 & $1,033.52$ & $7,140.20$ & 57.85 & 693.51 \\
\hline 82 & 50,623 & 3330 & 926.46 & $6,106.68$ & 58.04 & 635.66 \\
\hline 83 & 47,293 & 3445 & 824.30 & $5,180.22$ & 57.19 & 577.62 \\
\hline 84 & 43,848 & 3535 & 727.86 & $4,355.92$ & 55.89 & 520.44 \\
\hline 85 & 40,313 & 3598 & 637.32 & $3,628.06$ & 54.17 & 464.55 \\
\hline 86 & 36,715 & 3566 & 552.79 & $2,990.74$ & 51.13 & 410.38 \\
\hline 87 & 33,149 & 3611 & 475.34 & $2,437.95$ & 49.31 & 359.24 \\
\hline 88 & 29,538 & 3583 & 403.39 & $1,962.61$ & 46.60 & 309.93 \\
\hline 89 & 25,955 & 3491 & 337.58 & $1,559.23$ & 43.24 & 263.33 \\
\hline 90 & 22,464 & 3290 & 278.26 & $1,221.65$ & 38.81 & 220.09 \\
\hline 91 & 19,174 & 2923 & 226.20 & 943.39 & 32.84 & 181.27 \\
\hline 92 & 16,251 & 2674 & 182.58 & 717.19 & 28.61 & 148.43 \\
\hline 93 & 13,577 & 2476 & 145.28 & 534.61 & 25.23 & 119.82 \\
\hline 94 & 11,101 & 2274 & 113.13 & 389.33 & 22.07 & 94.59 \\
\hline 95 & 8,827 & 2057 & 85.67 & 276.20 & 19.01 & 72.52 \\
\hline 96 & 6,770 & 1758 & 62.58 & 190.53 & 15.48 & 53.50 \\
\hline 97 & 5,012 & 1439 & 44.12 & 127.95 & 12.06 & 38.03 \\
\hline 98 & 3,573 & 1042 & 29.96 & 83.83 & 8.32 & 25.96 \\
\hline 99 & 2,531 & 779 & 20.21 & 53.88 & 5.92 & 17.64 \\
\hline 100 & 1,752 & 582 & 13.32 & 33.67 & 4.22 & 11.72 \\
\hline 101 & 1,170 & 420 & 8.47 & 20.34 & 2.90 & 7.50 \\
\hline 102 & 750 & 292 & 5.17 & 11.87 & 1.92 & 4.61 \\
\hline 103 & 458 & 193 & 3.01 & 6.70 & 1.21 & 2.69 \\
\hline 104 & 265 & 78 & 1.66 & 3.69 & 0.46 & 1.48 \\
\hline 105 & 187 & 93 & 1.11 & 2.03 & 0.53 & 1.02 \\
\hline 106 & 94 & 50 & 0.53 & 0.92 & 0.27 & 0.49 \\
\hline 107 & 44 & 25 & 0.24 & 0.38 & 0.13 & 0.22 \\
\hline 108 & 19 & 12 & 0.10 & 0.15 & 0.06 & 0.09 \\
\hline 109 & 7 & 5 & 0.03 & 0.05 & 0.02 & 0.03 \\
\hline 110 & 2 & 1 & 0.01 & 0.01 & 0.00 & 0.01 \\
\hline 111 & 1 & 1 & 0.00 & 0.00 & 0.00 & 0.00 \\
\hline
\end{tabular}




\section{\begin{tabular}{l|l} 
Pengantar Matematika Aktuaria & 2018
\end{tabular}}

LAMPIRAN VI. TABEL KOMUTASI 6\% (PEREMPUAN)

\begin{tabular}{|c|c|c|c|c|c|c|}
\hline $\mathbf{x}$ & $\mathbf{I}_{\mathbf{x}}$ & $\mathbf{d}_{\mathbf{x}}$ & $\mathbf{D}_{\mathbf{x}}$ & $\mathbf{N}_{\mathbf{x}}$ & $\mathbf{C}_{\mathbf{x}}$ & $\mathbf{M}_{\mathbf{x}}$ \\
\hline 0 & 100,000 & 370 & $100,000.00$ & $1,730,798.51$ & 349.06 & $2,030.27$ \\
\hline 1 & 99,630 & 56 & $93,990.57$ & $1,630,798.51$ & 49.84 & $1,681.22$ \\
\hline 2 & 99,574 & 42 & $88,620.51$ & $1,536,807.95$ & 35.26 & $1,631.38$ \\
\hline 3 & 99,532 & 33 & $83,568.99$ & $1,448,187.44$ & 26.14 & $1,596.11$ \\
\hline 4 & 99,499 & 28 & $78,812.53$ & $1,364,618.46$ & 20.92 & $1,569.97$ \\
\hline 5 & 99,471 & 27 & $74,330.52$ & $1,285,805.93$ & 19.03 & $1,549.05$ \\
\hline 6 & 99,444 & 30 & $70,104.10$ & $1,211,475.41$ & 19.95 & $1,530.02$ \\
\hline 7 & 99,414 & 31 & $66,115.99$ & $1,141,371.32$ & 19.45 & $1,510.06$ \\
\hline 8 & 99,383 & 30 & $62,354.12$ & $1,075,255.33$ & 17.76 & $1,490.61$ \\
\hline 9 & 99,353 & 28 & $58,806.89$ & $1,012,901.20$ & 15.64 & $1,472.86$ \\
\hline 10 & 99,325 & 25 & $55,462.56$ & $954,094.32$ & 13.17 & $1,457.22$ \\
\hline 11 & 99,300 & 24 & $52,310.00$ & $898,631.75$ & 11.93 & $1,444.05$ \\
\hline 12 & 99,276 & 26 & $49,337.13$ & $846,321.75$ & 12.19 & $1,432.13$ \\
\hline 13 & 99,250 & 28 & $46,532.27$ & $796,984.62$ & 12.38 & $1,419.94$ \\
\hline 14 & 99,222 & 29 & $43,885.99$ & $750,452.35$ & 12.10 & $1,407.55$ \\
\hline 15 & 99,193 & 28 & $41,389.77$ & $706,566.36$ & 11.02 & $1,395.45$ \\
\hline 16 & 99,165 & 25 & $39,035.93$ & $665,176.59$ & 9.28 & $1,384.43$ \\
\hline 17 & 99,140 & 24 & $36,817.07$ & $626,140.66$ & 8.41 & $1,375.14$ \\
\hline 18 & 99,116 & 23 & $34,724.68$ & $589,323.59$ & 7.60 & $1,366.74$ \\
\hline 19 & 99,093 & 24 & $32,751.53$ & $554,598.91$ & 7.48 & $1,359.13$ \\
\hline 20 & 99,069 & 26 & $30,890.18$ & $521,847.39$ & 7.65 & $1,351.65$ \\
\hline 21 & 99,043 & 29 & $29,134.03$ & $490,957.20$ & 8.05 & $1,344.00$ \\
\hline 22 & 99,014 & 33 & $27,476.89$ & $461,823.17$ & 8.64 & $1,335.96$ \\
\hline 23 & 98,981 & 37 & $25,912.95$ & $434,346.28$ & 9.14 & $1,327.32$ \\
\hline 24 & 98,944 & 39 & $24,437.05$ & $408,433.33$ & 9.09 & $1,318.18$ \\
\hline 25 & 98,905 & 42 & $23,044.73$ & $383,996.28$ & 9.23 & $1,309.09$ \\
\hline 26 & 98,863 & 43 & $21,731.08$ & $360,951.55$ & 8.92 & $1,299.86$ \\
\hline 27 & 98,820 & 45 & $20,492.10$ & $339,220.47$ & 8.80 & $1,290.94$ \\
\hline 28 & 98,775 & 47 & $19,323.37$ & $318,728.37$ & 8.67 & $1,282.14$ \\
\hline 29 & 98,728 & 50 & $18,220.92$ & $299,405.00$ & 8.71 & $1,273.46$ \\
\hline 30 & 98,678 & 53 & $17,180.84$ & $281,184.09$ & 8.71 & $1,264.76$ \\
\hline 31 & 98,625 & 56 & $16,199.63$ & $264,003.25$ & 8.68 & $1,256.05$ \\
\hline 32 & 98,569 & 59 & $15,274.00$ & $247,803.61$ & 8.62 & $1,247.38$ \\
\hline 33 & 98,510 & 61 & $14,400.80$ & $232,529.62$ & 8.41 & $1,238.75$ \\
\hline 34 & 98,449 & 63 & $13,577.25$ & $218,128.81$ & 8.20 & $1,230.34$ \\
\hline 35 & 98,386 & 66 & $12,800.53$ & $204,551.56$ & 8.10 & $1,222.14$ \\
\hline
\end{tabular}




\section{Pengantar Matematika Aktuaria 2018}

\begin{tabular}{|c|c|c|c|c|c|c|}
\hline $\mathbf{x}$ & $\mathbf{l}_{\mathrm{x}}$ & $\mathbf{d}_{\mathbf{x}}$ & $\mathbf{D}_{\mathrm{x}}$ & $\mathbf{N}_{\mathbf{x}}$ & $C_{x}$ & $\mathbf{M}_{\mathbf{x}}$ \\
\hline 36 & 98,320 & 73 & $12,067.87$ & $191,751.03$ & 8.45 & $1,214.04$ \\
\hline 37 & 98,247 & 83 & $11,376.33$ & $179,683.16$ & 9.07 & $1,205.59$ \\
\hline 38 & 98,164 & 91 & $10,723.32$ & $168,306.82$ & 9.38 & $1,196.52$ \\
\hline 39 & 98,073 & 102 & $10,106.96$ & $157,583.50$ & 9.92 & $1,187.14$ \\
\hline 40 & 97,971 & 112 & $9,524.95$ & $147,476.54$ & 10.27 & $1,177.23$ \\
\hline 41 & 97,859 & 123 & $8,975.53$ & $137,951.58$ & 10.64 & $1,166.95$ \\
\hline 42 & 97,736 & 138 & $8,456.84$ & $128,976.05$ & 11.26 & $1,156.31$ \\
\hline 43 & 97,598 & 154 & $7,966.89$ & $120,519.21$ & 11.86 & $1,145.05$ \\
\hline 44 & 97,444 & 171 & $7,504.07$ & $112,552.32$ & 12.42 & $1,133.19$ \\
\hline 45 & 97,273 & 188 & $7,066.89$ & $105,048.25$ & 12.89 & $1,120.76$ \\
\hline 46 & 97,085 & 208 & $6,653.99$ & $97,981.35$ & 13.45 & $1,107.88$ \\
\hline 47 & 96,877 & 232 & $6,263.90$ & $91,327.36$ & 14.15 & $1,094.43$ \\
\hline 48 & 96,645 & 259 & $5,895.19$ & $85,063.46$ & 14.90 & $1,080.28$ \\
\hline 49 & 96,386 & 288 & $5,546.60$ & $79,168.27$ & 15.64 & $1,065.37$ \\
\hline 50 & 96,098 & 321 & $5,217.00$ & & 16.44 & 049.74 \\
\hline 51 & 95,777 & 358 & $4,905.26$ & $68,404.67$ & 17.30 & $1,033.30$ \\
\hline 52 & 95,419 & 403 & $4,610.31$ & $63,499.41$ & 18.37 & $1,016.00$ \\
\hline 53 & 95,0 & 455 & & & 19.57 & 7.63 \\
\hline 54 & 94,561 & 513 & $4,066.26$ & 12 & 20.81 & 978.07 \\
\hline 55 & 94,048 & 571 & $3,815.28$ & $50,491.86$ & 21.85 & 57.25 \\
\hline 56 & 93,477 & 625 & $3,577.47$ & & 22.57 & 935.40 \\
\hline 57 & 92,852 & 673 & $3,352.41$ & .10 & 22.92 & 912.84 \\
\hline 58 & 92,179 & 715 & $3,139.73$ & $39,746.70$ & 22.98 & 889.91 \\
\hline 59 & 91,464 & 755 & $2,939.03$ & $36,606.97$ & 22.89 & 866.94 \\
\hline 60 & 90,709 & 796 & $2,749.78$ & $33,667.94$ & 22.76 & 844.05 \\
\hline 61 & 89,913 & 842 & $2,571.37$ & 16 & 22.72 & 821.29 \\
\hline 62 & 89,071 & 894 & & & 22.75 & 798.57 \\
\hline 63 & 88,177 & 973 & $2,244.33$ & $25,943.68$ & 23.36 & 775.82 \\
\hline 64 & 87,204 & 1059 & $2,093.92$ & $23,699.35$ & 23.99 & 752.45 \\
\hline 65 & 86,145 & 1149 & $1,951.41$ & 5.43 & 24.55 & 728.46 \\
\hline 66 & 84,996 & 1246 & $1,816.40$ & $19,654.02$ & 25.12 & 703.91 \\
\hline 67 & 83,750 & 1350 & $1,688.46$ & $17,837.62$ & 25.68 & 678.79 \\
\hline 68 & 82,400 & 1459 & $1,567.21$ & $16,149.16$ & 26.18 & 653.11 \\
\hline 69 & 80,941 & 1576 & $1,452.33$ & $14,581.94$ & 26.68 & 626.93 \\
\hline 70 & 79,365 & 1683 & $1,343.44$ & $13,129.62$ & 26.88 & 600.25 \\
\hline 71 & 77,682 & 1801 & $1,240.52$ & $11,786.18$ & 27.13 & 573.38 \\
\hline 72 & 75,881 & 1927 & $1,143.17$ & $10,545.65$ & 27.39 & 546.25 \\
\hline 73 & 73,954 & 2054 & $1,051.07$ & $9,402.49$ & 27.54 & 518.86 \\
\hline 74 & 71,900 & 2187 & 964.04 & $8,351.41$ & 27.66 & 491.32 \\
\hline 75 & 69,713 & 2321 & 881.81 & 7,387.37 & 27.70 & 463.65 \\
\hline
\end{tabular}




\section{\begin{tabular}{l|l} 
Pengantar Matematika Aktuaria & 2018
\end{tabular}}

\begin{tabular}{|c|c|c|c|c|c|c|}
$\mathbf{x}$ & $\mathbf{l}_{\mathbf{x}}$ & $\mathbf{d}_{\mathbf{x}}$ & $\mathbf{D}_{\mathbf{x}}$ & $\mathbf{N}_{\mathbf{x}}$ & $\mathbf{C}_{\mathbf{x}}$ & $\mathbf{M}_{\mathbf{x}}$ \\
\hline 76 & 67,392 & 2457 & 804.20 & $6,505.56$ & 27.66 & 435.96 \\
\hline 77 & 64,935 & 2592 & 731.02 & $5,701.37$ & 27.53 & 408.30 \\
\hline 78 & 62,343 & 2726 & 662.11 & $4,970.35$ & 27.31 & 380.77 \\
\hline 79 & 59,617 & 2855 & 597.32 & $4,308.24$ & 26.99 & 353.46 \\
\hline 80 & 56,762 & 2978 & 536.52 & $3,710.92$ & 26.56 & 326.47 \\
\hline 81 & 53,784 & 3161 & 479.60 & $3,174.40$ & 26.59 & 299.92 \\
\hline 82 & 50,623 & 3330 & 425.86 & $2,694.80$ & 26.43 & 273.32 \\
\hline 83 & 47,293 & 3445 & 375.33 & $2,268.94$ & 25.79 & 246.90 \\
\hline 84 & 43,848 & 3535 & 328.29 & $1,893.61$ & 24.97 & 221.10 \\
\hline 85 & 40,313 & 3598 & 284.74 & $1,565.32$ & 23.97 & 196.14 \\
\hline 86 & 36,715 & 3566 & 244.65 & $1,280.58$ & 22.42 & 172.16 \\
\hline 87 & 33,149 & 3611 & 208.38 & $1,035.94$ & 21.41 & 149.74 \\
\hline 88 & 29,538 & 3583 & 175.17 & 827.55 & 20.05 & 128.33 \\
\hline 89 & 25,955 & 3491 & 145.21 & 652.38 & 18.43 & 108.28 \\
\hline 90 & 22,464 & 3290 & 118.57 & 507.17 & 16.38 & 89.86 \\
\hline 91 & 19,174 & 2923 & 95.47 & 388.61 & 13.73 & 73.48 \\
\hline 92 & 16,251 & 2674 & 76.34 & 293.13 & 11.85 & 59.75 \\
\hline 93 & 13,577 & 2476 & 60.17 & 216.79 & 10.35 & 47.90 \\
\hline 94 & 11,101 & 2274 & 46.41 & 156.63 & 8.97 & 37.54 \\
\hline 95 & 8,827 & 2057 & 34.81 & 110.22 & 7.65 & 28.58 \\
\hline 96 & 6,770 & 1758 & 25.19 & 75.40 & 6.17 & 20.92 \\
\hline 97 & 5,012 & 1439 & 17.59 & 50.21 & 4.77 & 14.75 \\
\hline 98 & 3,573 & 1042 & 11.83 & 32.62 & 3.26 & 9.99 \\
\hline 99 & 2,531 & 779 & 7.91 & 20.79 & 2.30 & 6.73 \\
\hline 100 & 1,752 & 582 & 5.16 & 12.88 & 1.62 & 4.43 \\
\hline 101 & 1,170 & 420 & 3.25 & 7.72 & 1.10 & 2.82 \\
\hline 102 & 750 & 292 & 1.97 & 4.46 & 0.72 & 1.71 \\
\hline 103 & 458 & 193 & 1.13 & 2.50 & 0.45 & 0.99 \\
\hline 104 & 265 & 78 & 0.62 & 1.36 & 0.17 & 0.54 \\
\hline 105 & 187 & 93 & 0.41 & 0.75 & 0.19 & 0.37 \\
\hline 106 & 94 & 50 & 0.20 & 0.33 & 0.10 & 0.18 \\
\hline 107 & 44 & 25 & 0.09 & 0.14 & 0.05 & 0.08 \\
\hline 108 & 19 & 12 & 0.04 & 0.05 & 0.02 & 0.03 \\
\hline 109 & 7 & 5 & 0.01 & 0.02 & 0.01 & 0.01 \\
\hline 110 & 2 & 1 & 0.00 & 0.00 & 0.00 & 0.00 \\
\hline 111 & 1 & 1 & 0.00 & 0.00 & 0.00 & 0.00 \\
\hline
\end{tabular}




\section{\begin{tabular}{l|l} 
Pengantar Matematika Aktuaria & 2018
\end{tabular}}

\section{LAMPIRAN VII. KUNCI JAWABAN LATIHAN}

\section{Bab II}

1. Rp.16.800.000,-

2. Rp.6.755.685,-;

Rp.244.315,-

3. a. Rp.225.000.000,-;

b. 8 tahun.

4. 0,0682341

5. $\quad 0,0720737$

6. 3,02 tahun lagi.

7. 0,227738

8. Rp.34.136.148,-;

Rp.32.157.796,-

9. Rp.279.163.743,-

10. Rp.14.332.187,-

11. 0,10076336;

Rp.5.676.667,-

12. $\mathrm{d}=18,00074 \%$;

$\mathrm{i}=21,95232 \%$

13. Rp.26.084.944,-

14. Pilihan (b)

15. Rp.12.254.420,-

16. Rp.121.565.911,-

17. Rp.54.551.166,-; Rp.57.898.619,-

18. a. B.

b. 15 bulan lagi.

c. B 


\section{\begin{tabular}{l|l} 
Pengantar Matematika Aktuaria & 2018
\end{tabular}}

\section{Bab III}

2. Rp.46.597.979,-

3. Rp.1.052.831.559,-

4. Pilihan a.

5. Cukup;

Kelebihan Rp.482.978,-

6. Rp.347.928.642,-

7. 40 kali;

Rp.464.485,-

8. 0,251869841 ;

0,283079422

9. Rp.34.295.562,-

10. a) 27 kali

b) Rp.2.840.764,-

c) Rp.2.897.579,-

11. Pilihan c.

12. Pilihan c.

\section{Bab IV}

2. 0,761719

3. 0,210256

4. 0,504

5. 0,0931476

6.

\begin{tabular}{|c|c|c|c|c|c|}
\hline $\mathbf{x}$ & lx & dx & px & $\mathbf{q X}$ & ex \\
\hline 70 & 801 & 315 & 0.60674 & 0.39326 & 0.98002 \\
\hline 71 & 486 & 226 & 0.53498 & 0.46502 & 0.61523 \\
\hline 72 & 260 & 221 & 0.15000 & 0.85000 & 0.15000 \\
\hline 73 & 39 & 39 & - & 1.00000 & - \\
\hline 74 & - & & & & \\
\hline
\end{tabular}

7. 0,658901861

8. 0,01683266

9. $1 /(100-\mathrm{x})$ 


\section{Pengantar Matematika Aktuaria 2018}

10.

\begin{tabular}{|c|c|c|c|}
\hline $\mathrm{x}$ & $\begin{array}{c}\text { Peluang } \\
\text { meninggal }\end{array}$ & $\mathrm{l}_{\mathrm{x}}$ & $\mathrm{d}_{\mathrm{x}}$ \\
\hline 95 & 0.3333 & 1500 & 500 \\
\hline 96 & 0.4000 & 1000 & 400 \\
\hline 97 & 0.5000 & 600 & 300 \\
\hline 98 & 0.6667 & 300 & 200 \\
\hline 99 & 1.0000 & 100 & 100 \\
\hline 100 & - & 0 & - \\
\hline
\end{tabular}

11.

\begin{tabular}{|c|c|c|c|c|c|}
\hline $\mathrm{x}$ & $\mathrm{l}_{\mathrm{x}}$ & $\mathrm{d}_{\mathrm{x}}$ & $\mathrm{p}_{\mathrm{x}}$ & $\mathrm{q}_{\mathrm{x}}$ & $\mathrm{e}_{\mathrm{x}}$ \\
\hline 95 & 1000 & 300 & 0.7000 & 0.3000 & 1.2100 \\
\hline 96 & 700 & 300 & 0.5714 & 0.4286 & 0.7286 \\
\hline 97 & 400 & 300 & 0.2500 & 0.7500 & 0.2750 \\
\hline 98 & 100 & 90 & 0.1000 & 0.9000 & 0.1000 \\
\hline 99 & 10 & 10 & 0.0000 & 1.0000 & 0.0000 \\
\hline 100 & & & & & \\
\hline
\end{tabular}

Bab V

2. $\quad 723$

3. Rp.7.284.782,-

4.
a. Rp.224.876.347,-
b. Rp.224.305.619,-

5.

\begin{tabular}{|c|c|c|c|c|c|c|}
\hline $\mathbf{x}$ & $\mathbf{l}_{\mathbf{x}}$ & $\mathbf{d}_{\mathbf{x}}$ & $\mathbf{q}_{\mathbf{x}}$ & $\mathbf{p}_{\mathbf{x}}$ & $\mathbf{a}_{\mathbf{x}}$ & $\mathbf{e}_{\mathbf{x}}$ \\
\hline 95 & 900 & 200 & 0.2222 & 0.7778 & 1.3333 & 1.5000 \\
\hline 96 & 700 & 350 & 0.5000 & 0.5000 & 0.8343 & 0.9286 \\
\hline 97 & 350 & 140 & 0.4000 & 0.6000 & 0.7853 & 0.8571 \\
\hline 98 & 210 & 120 & 0.5714 & 0.4286 & 0.4005 & 0.4286 \\
\hline 99 & 90 & 90 & 1.0000 & - & - & - \\
\hline 100 & 0 & & & & & \\
\hline
\end{tabular}

6. Rp.12.124.192,-

7. Rp.439.956.865,-

8. Rp.36.961.895,- 


\section{\begin{tabular}{l|l} 
Pengantar Matematika Aktuaria & 2018
\end{tabular}}

\section{Bab VI}

2. 0,625

3. 0,882

4. $26-0,338 \mathrm{x}$;

$0,013 x /(26-0,338 x)$

5. Rp.1.785.844,-;

Rp.11.330.357,-

6. a. M15/(N15-N35);

b. (M20-M55+D55)/(N20-N30)

7. Rp.108.464.841,-

8. Rp. 334.504.011,-

9. a. Rp.1.158.504,-

b. Rp.5.836.221,-

c. Rp.462.683,-

10. Rp.206.853,-

11. 0,5 ;

0,005

12. 0,000877

13. Rp.385.576.598,-

14. Rp.6.087.913,-

\section{Bab VII}

2. Rp.103.238.165,-

3. a. Rp.4.924.358,-

b. Rp.230.354.440,-

c. Rp.363.556.243,-

4. $1 / 3$ dan $1 / 2$.

5. 0,24

6. 0,32 